Dissertação de Mestrado No95

\title{
DISTRIBUIÇÃO E PROPRIEDADE HIDRÁULICA DOS SOLOS DA VÁRZEA DE CURUAI, PARÁ
}

Área de concentração: Hidrogeologia e Meio Ambiente

\author{
Álvaro Xavier Ferreira
}

Orientador: Jérémie Garnier

BRASÍLIA, MARÇO DE 2016 
Dissertação de Mestrado No095

\title{
DISTRIBUIÇÃO E PROPRIEDADE HIDRÁULICA DOS SOLOS DA VÁRZEA DE CURUAI, PARÁ
}

\author{
Álvaro Xavier Ferreira
}

Banca Examinadora:

Prof. Dr.: Jérémie Garnier (UnB)

Dr.: Michel Brossard (IRD)

Prof. Dr: José Eloi Guimarães Campos (UnB)

BRASÍLIA, MARÇO DE 2016 


\section{AGRADECIMENTOS}

Em primeiro lugar, agradeço a Deus, pelo dom da vida e por me dar saúde e forças para perseverar em busca dos meus sonhos e objetivos. Que esse trabalho seja só o começo de mais uma caminhada a procura do conhecimento! Em segundo lugar, agradeço a Universidade de Brasília. O berço da minha formação, meu generoso lar desde 2009, da qual tenho muito orgulho e me sinto extremamente honrado por ser estudante. A UnB me transformou em quem eu sou, e a ela sou extremamente grato.

Agradeço imensamente ao meu orientador, Jérémie Garnier. A ele devo muito do meu crescimento profissional e pessoal dos últimos anos. Obrigado pela oportunidade, por toda a paciência, pelas boas conversas e pela amizade!

Um agradecimento especial fica aqui registrado aos meus companheiros de campo: Lucas Garcia, Eudes Bonfim e Yumi Parralego que sempre estiveram dispostos a me ajudar em todas as situações.

Agradeço também a todas as amizades construídas durante a realização desse trabalho. Cleber Kraus, Eva Haentjens, Gustavo Melo, Julie Roussel, Leonardo Gomes, Ana Carolina, Marie Flore, Mariana Câmara, Sébastien Pinel, Marie Paule Bonnet, Nivaldo Fonseca, e todas as pessoas que participaram desse Projeto. Nossas missões e experiências em campo ficarão marcadas para sempre em meu coração e memória.

Obrigado também ao povo do Lago Grande de Curuai. Essa pesquisa não teria acontecido sem vocês e foi por vocês que a fizemos. Agradeço a vocês por me mostrarem que seu modo de vida, tão distante do meu, garoto urbano, tem sua singularidade e enorme valor. Não há sabedoria maior do que viver as margens do maior rio do mundo e conviver respeitosamente com essas verdadeiras forças da natureza que são o rio Amazonas e a Floresta Amazônica. O Lago Grande do Curuai me mostrou que os ribeirinhos tem mais conhecimento sobre a floresta do que qualquer acadêmico.

Agradeço a minha família, meu pai, Alnir, minha mãe Anatécia, minha irmã Teciana, sem vocês eu não chegaria aqui!

Agradeço imensamente a minha namorada - incrível - Lorena Gabriela Santana Meireles. Obrigado por toda a ajuda, suporte, força e confiança que você me deu, desde a graduação até esse momento. Obrigado por toda a fé depositada em mim, sem você nada disso seria possível. 
Agradeço também à Coordenação de Aperfeiçoamento de Pessoal de Nível Superior (CAPES), pelo auxílio financeiro para o desenvolvimento das atividades do mestrado; à FRB (Fondation pour la Recherche sur la Biodiversité (FRB), ao IRD (Institut de Recherche pour le Développement, e ao LMI (Laboratório Misto Internacional) pelo apoio para as atividades de campo.

Obrigado Vida! 
“It's going to be LEGEN....

Wait for it...

DARY!"

Barney Stinson 


\section{Resumo:}

As planícies de inundação ou várzeas, como a Várzea Lago Grande de Curuai, são sistemas de reciclagem de água e matéria que ocorrem ao longo da Bacia Amazônica e em diversas partes do mundo. Embora haja um grande interesse por parte de diversos pesquisadores ao redor mundo em estudar a Bacia Amazônica, pouco se sabe sobre os ambientes de várzea da Bacia. Hoje em dia, acredita-se que estes ambientes estejam ameaçados pelas mudanças climáticas e ambientais e mais particularmente pelas crescentes pressões antrópicas, atuando em escala regional e local. Esta dissertação enquadra-se dentro do projeto científico Clim-FABIAM. Um dos objetivos do projeto Clim-FABIAM é o aprimoramento do software de modelagem da várzea, o qual foi criado com base em levantamentos que vem sendo realizados há mais de dez anos, cujo objetivo é entender melhor como as atividades antrópicas influenciam o regime hidrológico e a qualidade das águas das várzeas e prever a sua evolução em resposta a vários cenários climáticos e diferentes usos dos recursos naturais. Porém, o modelo apresenta algumas limitações, principalmente em relação aos dados pedológicos.

A fim de colaborar com interdisciplinaridade do projeto Clim-FABIAM e ampliar os conhecimentos sobre os solos da região, este estudo tem como principais objetivos gerar um mapa pedológico específico para a várzea de Curuai, avaliar as propriedades físico-químicas dos solos em vários contextos de cobertura vegetal e uso da terra, e identificar os possíveis impactos antrópicos aos solos da bacia de estudo.

Um novo mapa pedológico da região foi proposto, baseado em mais de 100 pontos de coleta de dados. Os resultados permitiram dividir a área de estudo em duas zonas: a zona de terra firme, composta basicamente por latossolos distróficos com textura arenosa, onde há um predomínio de quartzo e caulinita; e a zona de várzea, onde observa-se a predominância de gleissolos háplicos de textura argilo-siltosa e composição mineralógica diversificada, marcada principalmente por quartzo, caulinita, ilita, anatásio e esmectita. A assembléia mineralógica dos solos não apresentou modificações perceptíveis de acordo com o uso dos solos, ao contrário da condutividade hidráulica dos solos que varia de acordo com o seu uso e com a estação hidrológica do sistema. Esse estudo também utilizou isótopos de $\partial^{2} \mathrm{H}(\partial \mathrm{D})$ e $\partial^{18} \mathrm{O}$ a fim de melhor identificar as fontes de água que abastecem a bacia de estudo. Esses traçadores revelaram que o rio Amazonas, os igarapés e os lençóis freáticos são os principais fornecedores de água para o Lago, sendo que o rio Amazonas apresenta maior influência que os outros compartimentos na assinatura isotópica da água do Lago. 


\begin{abstract}
:
The flood plains or wetlands like Várzea Lago Grande de Curuai are water and matter recycling systems that occur throughout the Amazon Basin and in various parts of the world. Although there is a great interest around the world to study the Amazon Basin, particularly Floodplain environments. Nowadays, it is believed that these environments are threatened by climate and environmental changes and more particularly by the increasing human pressures act at a regional and local scale. This work falls within the Clim-FABIAM scientific project. One of the goals of the Clim-FABIAM project is the improvement of the modeling of floodplain software, which was created based on surveys conducted for over ten years. It aims to better understand how human activities affect the hydrological regime and water quality of wetlands and predict its evolution in response to various climate scenarios and different uses of natural resources. However, the model suffers some limitations, especially in relation to soil-related data.

In order to collaborate with interdisciplinary Clim-FABIAM project and expand the knowledge of regional pedology, the main objective is to generate a specific soil map for Curuai's floodplain, evaluate the physical and chemical properties of soils in various contexts vegetation and land use, and identify potential human impacts to soils of the study basin.

The new soil map of the region was based on over 100 points of data collection. The results allowed dividing the study area into two zones. The upland area where there is a predominance of dystrophic Oxisols with sandy texture and mineralogy consists mainly of quartz and kaolinite. Lowland areas, where we observe a predominance of Gleysols Haplic of clay and silty texture and diverse mineralogy, marked by minerals such as quartz, kaolinite, illite, smectite and anatase. The soil mineralogy has no noticeable changes according to the land use, unlike the hydraulic conductivity of soils that varies according to its use and the hydrological station system. This study also used water isotopes $\left(\partial^{2} \mathrm{H}(\partial \mathrm{D})\right.$ e $\left.\partial^{18} \mathrm{O}\right)$ as tracer in order to understand more about the water sources that supply the basin study. These tracers revealed that the Amazon River, local streams and groundwater are the main water supplier for the Lake. Amazon River has more influence than the other compartments in the isotopic signature of the water of Lake.
\end{abstract}




\section{Sumário}

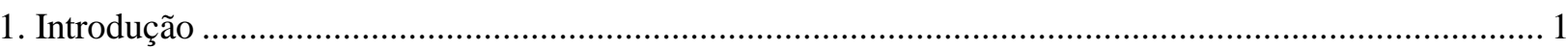

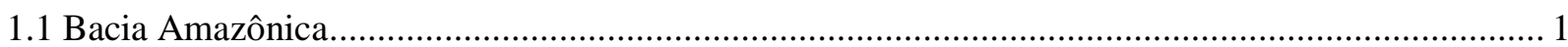

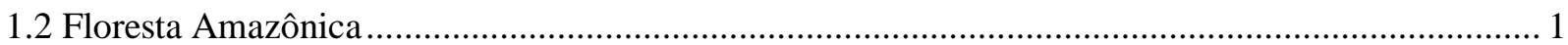

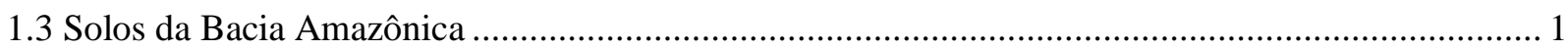

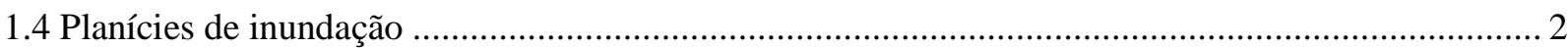

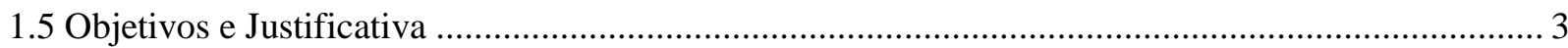

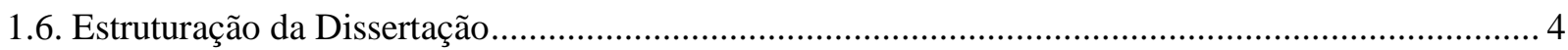

2. Revisão bibliográfica - Caracterização Regional ................................................................................. 5

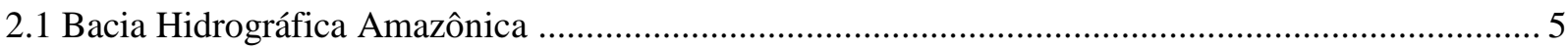

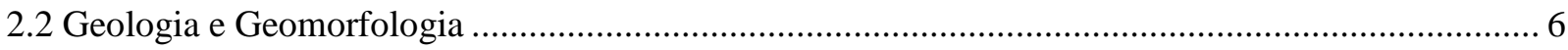

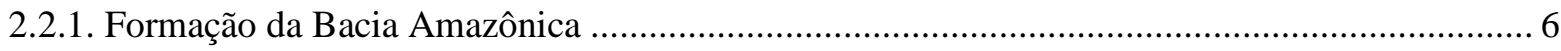

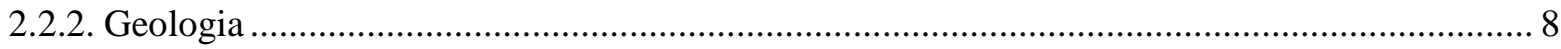

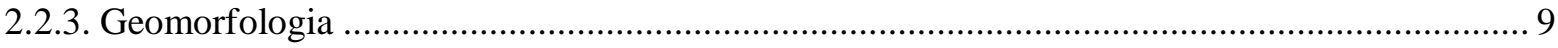

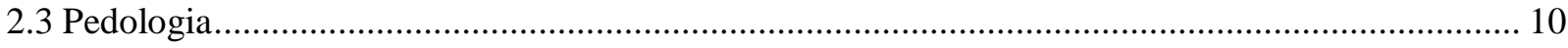

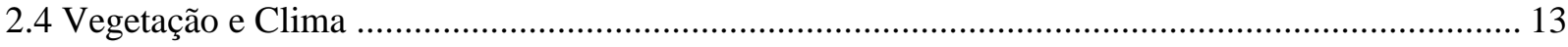

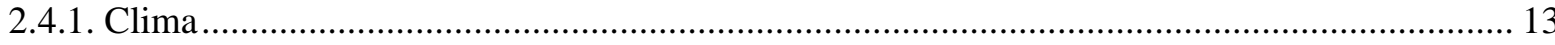

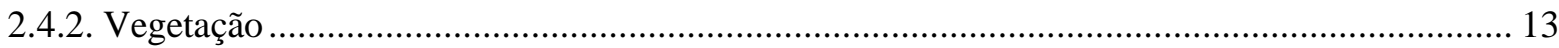

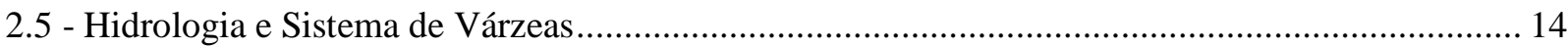

3- Área de Estudo: Várzea do Lago Grande de Curuai .......................................................................... 17

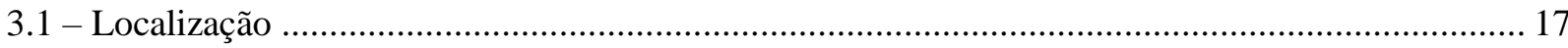

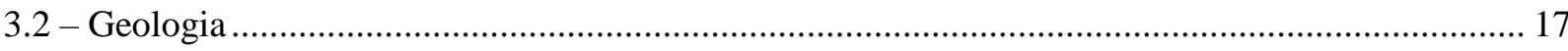

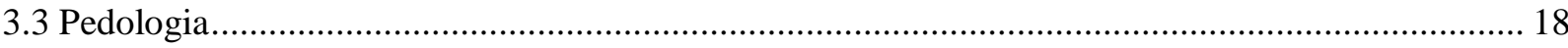

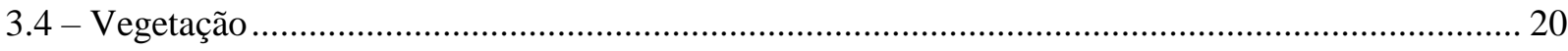

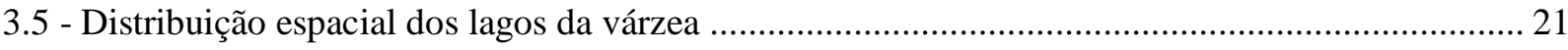

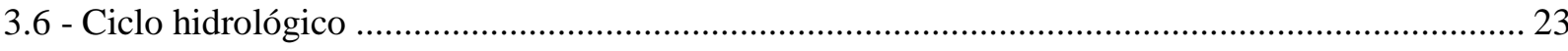

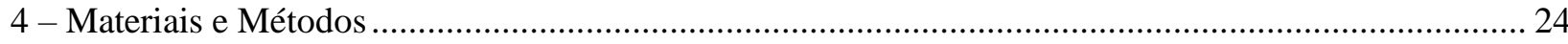

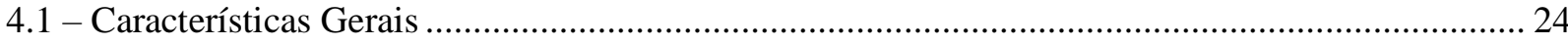

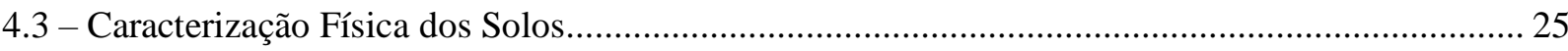

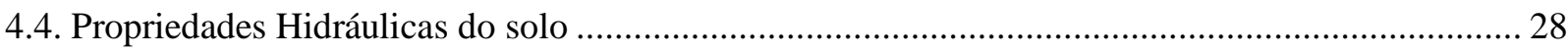

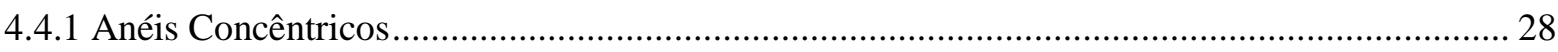

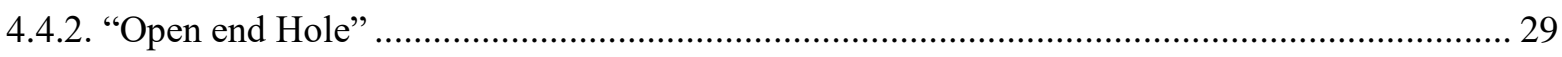

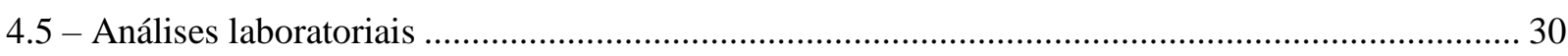

4.5.1 - Análises de Mineralogia por Difratometria de Raio-X (DRX) …....................................... 30

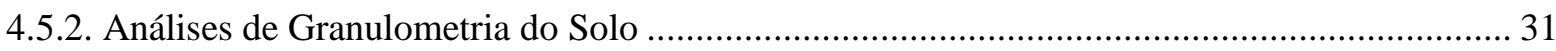

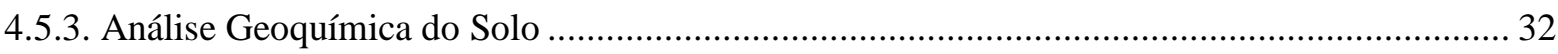


4.6. Análise Isotópica de Água

4.6.1 - Conceito:

4.7 - Softwares utilizados

5 - Resultados e Discussão:

5.1 - Distribuição espacial dos pontos coletados durante as campanhas de campo 38

5.2 - Características dos Solos 39

5.2.1 - Classificação Textural 40

5.2.2 - Mineralogia dos solos (Análise por difratometria de Raios-X). 43

5.3 - Geoquímica e Perda ao Fogo....

5.4 - Mapa Pedológico .55

5.5 - Ensaios de Infiltração .59

5.6 - Isótopos de $\partial^{2} \mathrm{H}$ e $\partial^{18} \mathrm{O}$. 65

6 - Conclusão .75

7. Bibliografia 81

8. Anexos 87

\section{Lista de Figuras}

Figura 1 - Em fundo amarelo destaca-se a Bacia Amazônica. A figura apresenta o rio Amazonas e seus principais tributários. (Fonte: Amazonriverbasin_basemap).

Figura 2 - Limites geomorfológicos (atuais) da Bacia Amazônica. (Fonte: Amorim, 2006).

Figura 3 - Modelo simplificado da evolução interna da Bacia Amazônica. As figuras acima (de A a F) retratam as mudanças ocorridas na Bacia Amazonica no intervalo de 65 milhões de anos a 2,5 milhões de anos atrás com o soerguimento da Cordilheira dos Andes - em vermelho. Imagens: Science- joaquimnery .files. wordpress. com_2015_05_biodiversidadeamazonia 03).

Figura 4 - Mapa geológico da bacia Amazônica. Fonte: Clim Amazon (http://www.climamazon.eu/content/view/full/51654) (modificado SANCHEZ et al., 2015).

Figura 5 - Modelo esquemático de um perfil Norte-Sul (NW-SE) na Bacia Amazônica (ROSS, 1990). .. 10 Figura 6 - Perfil esquemático do relevo da Bacia Amazônica e disposição representativa da vegetação nas proximidades da área de estudo (Fonte: http://marcosbau.com.br/wp-content/uploads/2010/05/degrausamazonia1.png).

Figura 7 - Representação das interações água/materiais que ocorrem na Várzea (Junk et al. 1989).......... 16 Figura 8 - Localização da área de estudo - destacada em contorno vermelho os limites da bacia hidrográfica. A porção norte representa a área periodicamente alagada (zona de várzea), o contorno sul representa a área de terra firme, que dificilmente é alagada.

Figura 9 - Mapa geológico da área feito a partir da base de dados do IBGE e CPRM sobreposto a compilação das cartas de relevo: SA-21-Z-A, SA-21-Z-B, SA-21-Z-C e SA-21-Z-D retiradas da base de dados da EMBRAPA e trabalhadas com a ferramenta hillshade do Arcgis 10. Os limites da área de estudo estão delimitados pela linha de cor vermelha.

Figura 10 - Mapa pedológico da área de estudo (gerado no Arcgis 10.1 a partir da Base de Dados da Embrapa e do IBGE).

Figura 11 - Distribuição vegetal da área de estudo segundo TerraClass 2010 (Fonte INPE - Instituto Nacional de Pesquisas Espaciais - compilação das cartas: TC_2010_22862 e TC_2010_22861). 
Figura 12 - Principais lagos da área de estudo. Destacada pela elipse preta, observa-se a chamada "boca do lago Grande de Curuai" e em azul mais claro estão representados os traçados dos principais igarapés da área (A base de dados hidrográfica pertencente ao IBGE - com modificações. Imagem representativa da várzea no período da seca de outubro de 2011 - fonte: INPE).

Figura 13 - Pontos estudados durante as missões do projeto Clim-FABIAM para coleta de informações. (Fonte: INPE, imagem referente a seca de outubro de 2011).

Figura 14 - Prancha exemplificativa dos parametrôs utilizados em campo para caracterização e

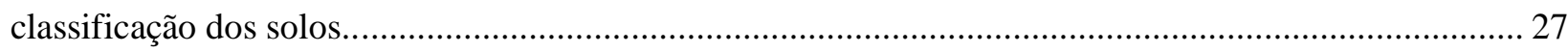

Figura 15 - Modelo esquemático do funcionamento dos anéis concêntricos. ......................................... 29

Figura 16 - Modelo esquemático do funcionamento do método "open end hole"..................................... 30

Figura 17 - Efeitos/ causas de fracionamento isotópico da água............................................................. 36

Figura 18 - Distribuição espacial dos pontos visitados durante as missões do projeto Clim-FABIAM para coleta de informações pedológicas. (Fonte: INPE, imagem referente a seca de outubro de 2011)............ 38 Figura 19 - Representação das duas principais zonas da área de estudo. (Imagem da várzea em outubro de 2011, retirada do INPE, sobreposta a imagem fornecida pelo BaseMap do Arcgis 10.1)........................ 40 Figura 20- Distribuição dos teores de areia contra teores de argila de uma seleção de amostras de solos da Terra Firma (quadrado verde) e da área de Várzea (losango cinza) ....................................................... 43 Figura 21 - Difratograma representativo da mineralogia típica dos solos de terra firme (DRX da amostra 005: 0-20) (T: fração TFSA, N: fina - argila, G: glicolada, Aq: aquecida). ....................................... 45 Figura 22 - Difratograma representativo da mineralogia típica dos solos de várzea (DRX da amostra 068: 20-40) (T: fração TFSA, N: fina - argila, G: glicolada, A: aquecida).

Figura 23- Relação entre A) Teor de $\mathrm{Fe}_{2} \mathrm{O}_{3}$ e CIA (Índice de intemperismo), B) Teor de $\mathrm{TiO}_{2}$ e CIA, C) Teor de $\mathrm{SiO}_{2}$ contra CIA, D- entre Teores de $\mathrm{Al}_{2} \mathrm{O}_{3}$ e $\mathrm{TiO}_{2}$; com as solos de Terra firme representados pelos quadrados verdes e os solos da Várzea pelos losangos cinzas.

Figura 24- A- Perda ao fogo em função da profundidade, B- a soma de macronutrientes $\left(\mathrm{CaO}, \mathrm{Na}_{2} \mathrm{O}\right.$, $\mathrm{K}_{2} \mathrm{O}$ ) nas amostras de Terra firme (quadrado verde) e as amostras de Várzea (losangos cinza). Os maiores valores de nutrientes e de carbono orgânico (PF) concentram-se nos centímetros superficiais do perfil de solo.

Figura 25 - Relação entre o teor de $\mathrm{SiO} 2$ e a quantidade (\%) de argila ou areia dos solos de Terra firme (quadrado verde) e da Várzea (losango cinza)...

Figura 26- Teor em Carbono orgânico total em função da profundidade de uma seleção de solos da bacia (amostras de terra firme: 5, 6, 32, 37, 38, 45, 112, 113, 114; amostras de várzea: 62, 65, 68, 69, 81, 111).

Figura 27 - Mapa pedológico da EMBRAPA retratando a área de Estudo.

Figura 28 - Mapa pedológico da área de estudo. Apresentação de todos os pontos de análise pedológica sobrepostos ao modelo digital de terreno e à imagem de satélite da bacia adquirida no período da seca (outubro/2011).

Figura 29 - Distribuição espacial dos pontos analisados apresentados sobre um mapa integrado de relevo e pedologia. A linha branca pontilhada representa o transecto base utilizado como guia para a realização dos ensaios de infiltração.

Figura 30 - Representação esquemática do relevo da porção seccionada pelo transecto base. (Essa representação foi feita com o auxílio da ferramenta "perfil de elevação" do software Google Earth). Analisando o transecto de norte a sul temos: de 0 a 1 a porção que fica dentro dos limites da zona de várzea; a partir de 1 , no sentido Sul, temos o relevo da zona de terra firme. O espaço de 0 a 1 esta sob um gleissolo háplico, de 1 a 2, tem-se a predominância do latossolo amarelo e a partir de 2 (sentido sul) temse a predominância do latossolo vermelho.

Figura 31 - Distribuição espacial das amostras de água coletadas para análise isotópica. 65

Figura $32-\partial^{18} \mathrm{O}$ em função do $\partial \mathrm{D}$ de todas as amostras coletadas. 
Figura $33-\partial^{18} \mathrm{O}$ em função do $\partial \mathrm{D}$ de todas as amostras de chuvas coletadas. Os losangos azuis representam as amostras de água da chuva coletadas em campo; a reta vermelha representa a reta mundial das chuvas proposta por Craig et al. (1991).

Figura $34-{ }^{18} \mathrm{O}$ em função do $\partial \mathrm{D}$ de todas as amostras do Rio Amazona. Os pontos em verde e em azul representam a resposta isotópica da água do Rio na cheia e em vermelho tem-se a resposta da água do Rio durante a seca. Ano de coleta e época seria melhor que FAB

Figura 35- $\partial^{18} \mathrm{O}$ em função do $\partial \mathrm{D}$ de todas as águas subterrâneas da bacia em duas fases do ciclo hidrológico: cheia (representadas pelas cores azul -losango azul-, ano de 2014, e verde - triângulo verde2015) e seca 2014 (pontos em vermelho - quadrado vermelho).

Figura 36 - a- $\partial^{18} \mathrm{O}$ em função do $\partial \mathrm{D}$ de todos os Igarapés do Lago Grande de Curuai. Os pontos em verde e em azul representam a resposta isotópica da água na cheia e em vermelho tem-se a resposta da água dos igarapés durante a seca. $\mathrm{b}-\partial^{18} \mathrm{O}$ em função do $\partial \mathrm{D}$ de todas as águas subterrâneas e igarapés da área de estudo (os pontos em verde e em azul representam a resposta isotópica da água na cheia e em vermelho tem-se a resposta da água dos igarapés durante a seca). .71

Figura $37-\partial^{18} \mathrm{O}$ em função do $\partial \mathrm{D}$ de todas as águas do Lago Grande de Curuai. .................................... 71 Figura 38 - a- $\partial^{18} \mathrm{O}$ em função do $\partial \mathrm{D}$ de todas as águas coletadas durante a cheia de 2014 (FAB III). A linha tracejada representa o grau de mistura da água entre esses dois compartimentos. b- $\partial^{18} \mathrm{O}$ em função do $\partial \mathrm{D}$ de todas as águas coletadas durante época de seca 2014. As cruzes (+) azul e preta representam, respectivamente, os compartimentos Igarapé e rio Amazonas.

Figura 39 - Representação esquemática do transecto típico da área de estudo. Apresentação da litologia, pedologia e a condutividade hidráulica local. As proporções e escalas utilizadas são meramente ilustrativas. . 79

\section{Lista de Tabelas}

Tabela 1 - Tabela utilizada em campo para avaliação dos tipos de solo.

Tabela 2 - Descrição simplificada do local de coleta das amostras de solo.

Tabela 3 - Distribuição granulométrica (\% de argila, silte e areia) e classificação textural correspondente, segundo Lemos e Santos (1996), das amostras mais representativas dos tipos de solos da área de estudo. Em verde destacam-se as amostras da zona de terra firme, com textura predominante areia-franca e em cinza são apresentadas as amostras da zona de várzea, que possuem textura argilosa em sua maioria. ( $L Q$ : limite de quantificação ; A-F: AREIA-FRANCA, F-A: FRANCO-ARENOSA, F-S: FRANCO-SILTOSA, FA-Arg: FRANCO-ARGILA-ARENOSA, F: FRANCO, Arg: ARGILA, F-Arg: FRANCO-ARGILOSA, MArg: MUITO ARGILOSA).

Tabela 4 - Mineralogia das amostras total (TFSA) e fração argila de coletadas na zona de terra firme e de várzea

Tabela 5 - Apresentação dos dados obtidos até o momento para a elaboração do modelo conceitual pedológico da região.

Tabela 6- Composição quimica em óxidos das amostras analisadas em laboratório, e valor da perda ao fogo. O balanço de óxidos apresenta valores confiaveis, todos com resultados próximo ao $100 \%$. Na tabela tambem é apresentada o somatório de bases $\left(\mathrm{CaO}+\mathrm{Na}_{2} \mathrm{O}+\mathrm{K}_{2} \mathrm{O}\right)$ e a razão CIA $\left(\mathrm{Al}_{2} \mathrm{O}_{3} / \mathrm{Al}_{2} \mathrm{O}_{3}+\right.$ bases). (Legenda: TF = Terra Firme; e VARZ = Várzea) ............................................................. 50

Tabela 7 - Composição química dos sedimentos coletados na zona de várzea. (Araújo et al., 2014)........ 53

Tabela 8 - Breve descrição quanto a vegetação e o tipo de solo do local de análise................................. 61 Tabela 9 - Resultados dos valores de Condutividade Hidraulica (Kv) dos pontos analisados (ver tabela 8 para dados complementares). Devido a proximidade a massas de água o ponto 43 apresentou valores de $\mathrm{Kv}$ muito próximos a $0 \mathrm{em} 50$ e $100 \mathrm{~cm}$ de profundidade e em $150 \mathrm{~cm}$ de profundidade foi atingindo a lamina d'água. 
Tabela 10 - Assinatura isotópica das águas coletadas nos diversos compartimentos de coleta de água. (Legendas: POÇO - PC; IGARAPÉ: IG; LAGO GRANDE: LA; CHUVA: CHUVAS; RIO AMAZONAS: RIO) (as terminações $\mathrm{C}$ e $\mathrm{S}$ refem-se aos períodos de Cheia e Seca respectivamente) (os termos FAB III, FAB IV e FAB V referem-se a campanha de coleta dos pontos: FAB III é a primeira campanha de campo: realizada entre os dias 25 de maio e 6 de junho de 2014, durante a época de cheia da bacia; FAB IV é a segunda campanha de campo: realizada entre os dias 24 de novembro e 3 de dezembro de 2014, durante a época de seca da Bacia;e FAB V é a terceira campanha de campo: realizada entre 4 de maio e 13 de maio de 2015).

Tabela 11 - Apresentação de forma simplificada da integração dos dados do estudo 78 


\section{Introducão}

\subsection{Bacia Amazônica}

A Bacia Amazônica é a maior bacia hidrográfica do planeta, possui uma área superior a seis milhões de $\mathrm{km}^{2}$. A descarga líquida média do seu principal rio, o Amazonas, é estimada em $209.000 \mathrm{~m}^{3} . \mathrm{s}^{-1}$ (Molinier et al., 1997).

\subsection{Floresta Amazônica}

De dimensões continentais, a Bacia Amazônica está situada na zona intertropical e apresenta clima e vegetação correspondente com esta zona. As elevadas temperaturas da região (média anual de aproximadamente $27^{\circ} \mathrm{C}$ ), a grande umidade atmosférica (variando entre 75,6\% e $86,7 \%$ ) e a rede hidrográfica da bacia possibilitam que esta área seja o berço da maior floresta tropical do mundo (Keddy et al., 2009).

Apesar da exuberância apresentada pela floresta, os solos nos quais está fixada - de maneira geral - não possuem grande riqueza em nutrientes. Os solos amazônicos possuem uma restrita camada superficial (serrapilheira) enriquecida em matéria orgânica (húmus). Essa fina camada fértil é oriunda da própria floresta, formada principalmente a partir da decomposição de folhas, galhos, frutos e animais mortos. Essa decomposição deve-se a complexos processos biológicos, físicos e químicos de modo que é correto afirmar que a serrapilheira apresenta grande importância na sustentação da floresta Amazônica, e ajuda a explicar como, apesar de possuir um solo geralmente pobre em nutrientes, a floresta permanece viva.

\subsection{Solos da Bacia Amazônica}

Os solos da Bacia Amazônica são derivados de material proveniente de terrenos cristalinos e depósitos sedimentares, e apresentam certa diversidade, sendo caracterizados especialmente, pela intensa lixiviação a que são submetidos.

Pelas características geomorfológicas, hidrogeológicas e climáticas da região, os solos podem ser classificados, genericamente, em solos de várzeas e solos de terra firme (Vieira e Santos, 1987).

Os solos de várzeas, localizados nas margens do rios, são adubados e drenados naturalmente pelas enchentes periódicas. São ricos em nutrientes e em matéria orgânica devido as aluviões que se depositam nas suas margens. São hidromórficos, geralmente argilo-arenosos e originários de terrenos sedimentares (terciários e quaternários). Podem ser aproveitados em culturas temporárias como arroz, junta e malva, mas não apresentam condições adequadas à mecanização das lavouras (Vieira e Santos, 1987). 
Já os solos de terra firme, com predominância dos latossolos, amarelos e vermelhos, são mais destinados a culturas permanentes ou de ciclos longos, como cacau e dendê. Esse solos são geralmente profundos, bem drenados e, como aparecem em áreas planas ou pouco acidentadas, oferecem condições adequadas à mecanização. Tem sua origem relacionada a sedimentos arenoargilosos dos períodos terciário e quaternário (Vieira e Santos, 1987).

A literatura também comenta sobre a presença de argissolos, cambissolos, gleíssolos, litossolos e neossolos.

\subsection{Planícies de inundação}

A Bacia Amazônica abriga uma das mais extensas áreas alagáveis do mundo (várzeas) (Keddy e Fraser, 2005). Estimativas recentes a respeito do mapeamento da largura da bacia usando imagens de satélite JERS-1 registram uma área inundável de cerca de $800.000 \mathrm{~km}^{2}$ (Melack e Hess, 2010; Salcedo, 2011). As várzeas, também chamadas de planícies de inundação, são áreas úmidas, periodicamente inundadas pelo transbordamento lateral de rios ou lagos, influenciados pelo regime de chuvas e/ou águas subterrâneas. Flutuações extensivas do nível de água resultam em típicas fases terrestres e fases aquáticas. Devido a processos de sedimentação desiguais, as planícies de inundação apresentam diferentes habitats, alguns com maior volume de água que outros: rios, lagos, várzeas, igapós, savanas, chavascais, buritizais e florestas (Sioli, 1984; Junk e Howard-Williams, 1984; Junk et al., 1989; Amorim, 2006; Forsberg et al., 2008; Wittmann et al., 2010; Salcedo, 2011).

Uma das principais características das planícies de inundação é o padrão sazonal de oscilação do nível da água, o pulso de inundação é centrado no intercâmbio lateral de água, nutrientes e organismos entre o canal do rio (ou lago) com a planície de inundação (Junk et al., 1989; Junk, 1997a). O conceito de pulsos de inundação é baseado nas características hidrológicas do rio, em sua bacia de drenagem e em sua planície de inundação - assim, esses pulsos são capazes de alterar a qualidade da água que transita pelas várzeas e igarapés e modificar as propriedades hidráulicas e químicas do solo. O grau de conexão entre o rio e a planície de inundação depende do nível d'água do rio (Amorim, 2006; Pérez, 2008; Salcedo, 2011).

As planícies de inundação na Amazônia tem um papel importante na ecologia, na economia e no balanço de água e de material (sedimentos e elementos químicos) que circulam pela região. São áreas altamente produtivas devido principalmente ao aporte de águas ricas em nutrientes e em material particulado provenientes do Rio Amazonas e apresentam grande biodiversidade. Estima-se que grande parte da vazão média e do material transportado pelo Rio Amazonas transitam pelas planícies de inundação (Mertes et al., 1996; Dunne et al., 1998; Maurice-Bourgoin et al., 2007; Pérez, 2008). 
As grandes inundações constituem fator limitante para a pecuária, pesca, caça, agricultura e impactam na ocupação das áreas de várzea, no desenvolvimento da região, gestão da água, transporte fluvial e condições sanitárias (Amorim, 2006).

Várias pesquisas sugerem que esses ambientes vem sendo fortemente impactados pelas mudanças climáticas e ambientais (por exemplo, com cheias históricas e períodos de seca muito prolongados) e mais particularmente pelas crescentes pressões antrópicas (atuando em escala regional - tais como desmatamento, construções de hidroelétricas, termoelétricas - e em escala local - como intensificação da pecuária, aumento demográfico, agricultura extensiva, usos da terra, intensificação da pesca e pesca "industrial”) resultando em profundas modificações desses ecossistemas, física, química e biologicamente (Junk et al. 1989; Amorin, 2006; MauriceBourgoin et al., 2007). Porém a falta de dados científicos (apresentados na forma de dados individuais ou integrados) sobre a região dificulta a confirmação e estimativa desses impactos.

\subsection{Objetivos e Justificativa}

Apesar da conhecida importância da Bacia Amazônica para o ecossistema mundial e do crescente interesse cientifico sobre a área, mais particularmente sobre as áreas de várzea, a escassez de dados científicos sobre esses ambientes dificulta a avaliação dos impactos sobre como as mudanças climáticas, ambientais e antrópicas vem afetando a região ao longo do tempo.

Esse mestrado enquadra-se dentro do projeto científico, Clim-FABIAM (Changements climatiques et biodiversité des lacs d'inondation dans le bassin Amazonien: Comment faire face et aider à la durabilité écologique et économique - "As alterações climáticas e a biodiversidade dos lagos de inundação na Bacia Amazônica : Como lidar e ajudar a sustentabilidade ecológica e econômica”).

Um dos objetivos do projeto é o desenvolvimento de um modelo hidrológico da várzea de Curuai para entender melhor como as atividades antrópicas influenciam o regime hidrológico e a qualidade de água das várzeas e prever a sua evolução em respostas a vários cenários climáticos e diferentes usos dos recursos naturais. Porém esse modelo apresenta limitações, principalmente em relação a escassez de dados sobre os tipos de solos presentes na porção de terra firme da Bacia de estudo e suas características físicas e químicas, já que o mapa pedológico da região foi feito com base em análises de imagens de satélite e não conta com descrições pedológicas específicas sobre a área de estudo.

Nesse contexto, este estudo se propôs a:

- Identificar os principais tipos de solos que ocorrem na Bacia do Lago Grande de Curuai (mapeamento pedológico); 
- Identificar as principais características físico-químicas desses solos (cor, textura, assembleia mineralógica, composição química, entre outras);

- Melhorar o conhecimento sobre a percolação da água no solo e os fluxos de água subterrânea (ensaios de infiltração, análise de condutividade hidráulica);

- Entender mais sobre os fluxos de água entre a zona terra firme e a área de várzea (análises isotópicas) e;

- Identificar possíveis alterações que a crescente ocupação humana na região pode ocasionar ou está ocasionando aos solos da área.

Este trabalho encaixa-se na continuação dos trabalhos de modelagem hidrológica da várzea de Curuai. Os dados obtidos serão usados para calibrar o modelo hidrológico na escala local da bacia da várzea de Curuai e servirão de suporte para a extrapolação na escala regional das planícies localizadas ao longo do curso principal do Rio Amazonas.

\subsection{Estruturação da Dissertação}

Esta dissertação foi dividida em oito capítulos: após essa introdução o segundo capítulo apresenta a caracterização regional da área, expondo, com base em diversos trabalhos científicos as principais características da Bacia Amazônica. O terceiro capítulo retrata as principais características da Várzea do Lago Grande de Curuai. O quarto capítulo apresenta as abordagens e metodologias implantadas. O quinto capítulo apresenta os resultados obtidos a respeito da pedologia da Várzea de Curuai e as assinaturas isotópicas das águas que circulam pela bacia. Finalmente, na conclusão é proposto um modelo conceitual do funcionamento pedológico e para a circulação das águas na bacia da Várzea de Curuai. 


\section{Revisão bibliográfica - Caracterização Regional}

\subsection{Bacia Hidrográfica Amazônica}

A Bacia do Rio Amazonas está localizada na porção noroeste da América do Sul (Figura 1) e abrange uma área de aproximadamente 6,1 milhões $\mathrm{km}^{2}$, com cerca de 3,9 milhões de $\mathrm{km}^{2}$ em território brasileiro. Situada entre os paralelos $5^{\circ}$ Norte e $20^{\circ}$ Sul e meridianos $46^{\circ}$ a $79^{\circ}$ Oeste, abrange $40 \%$ da área do continente Sul-americano e estende-se por sete países da América do Sul: Brasil (63\%), Peru (16\%), Bolívia (12\%), Colômbia (5,6\%), Equador (2,3\%), Venezuela (0,6\%) e Guiana (0,2\%) (Sioli, 1984; Molinier et al., 1996).

A Bacia representa um quinto de toda água fluvial escoada para o oceano e é a maior bacia fluvial do mundo (Molinier et al., 1996); segundo dados da Agência Nacional de Águas (ANA) possui 10 dos 20 maiores rios da Terra.

A nascente do rio Amazonas está inserida nos Andes peruanos. O principal rio, o Amazonas, é formado pela confluência do rio Solimões, resultado da união dos rios Ucayali e Maranõn, no Peru, nascidos nos Andes, com o rio Negro, vindo do Escudo das Guianas. Duzentos quilômetros a jusante, o rio Amazonas se encontra com o rio Madeira, vindo dos Andes Bolivianos. Os tributários que encontram o rio no médio Amazonas, Trombetas, Tapajós e Xingu são oriundos do Escudo Brasileiro. Por fim o rio Amazonas deságua no Oceano Atlântico (Belém, Pará) (Figura 1).

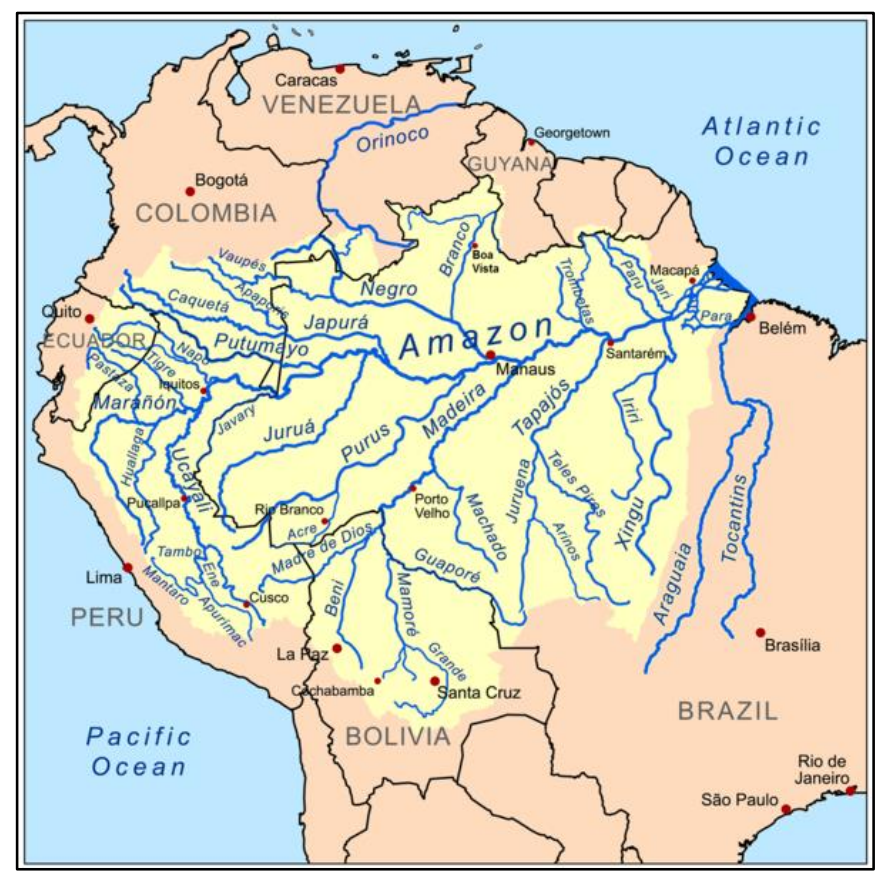

Figura 1 - Em fundo amarelo destaca-se a Bacia Amazônica. A figura apresenta o rio Amazonas e seus principais tributários. (Fonte: Amazonriverbasin_basemap). 


\subsection{Geologia e Geomorfologia}

\subsubsection{Formação da Bacia Amazônica}

A bacia Amazônica está situada entre escudos Pré-Cambrianos; é limitada a Norte pelo escudo das Guianas, a Sul pelo escudo Brasileiro, a Leste pelo Oceano Atlântico e a Oeste pela Cadeia Andina (Sioli, 1984; Molinier et al., 1996) (Figura 2).

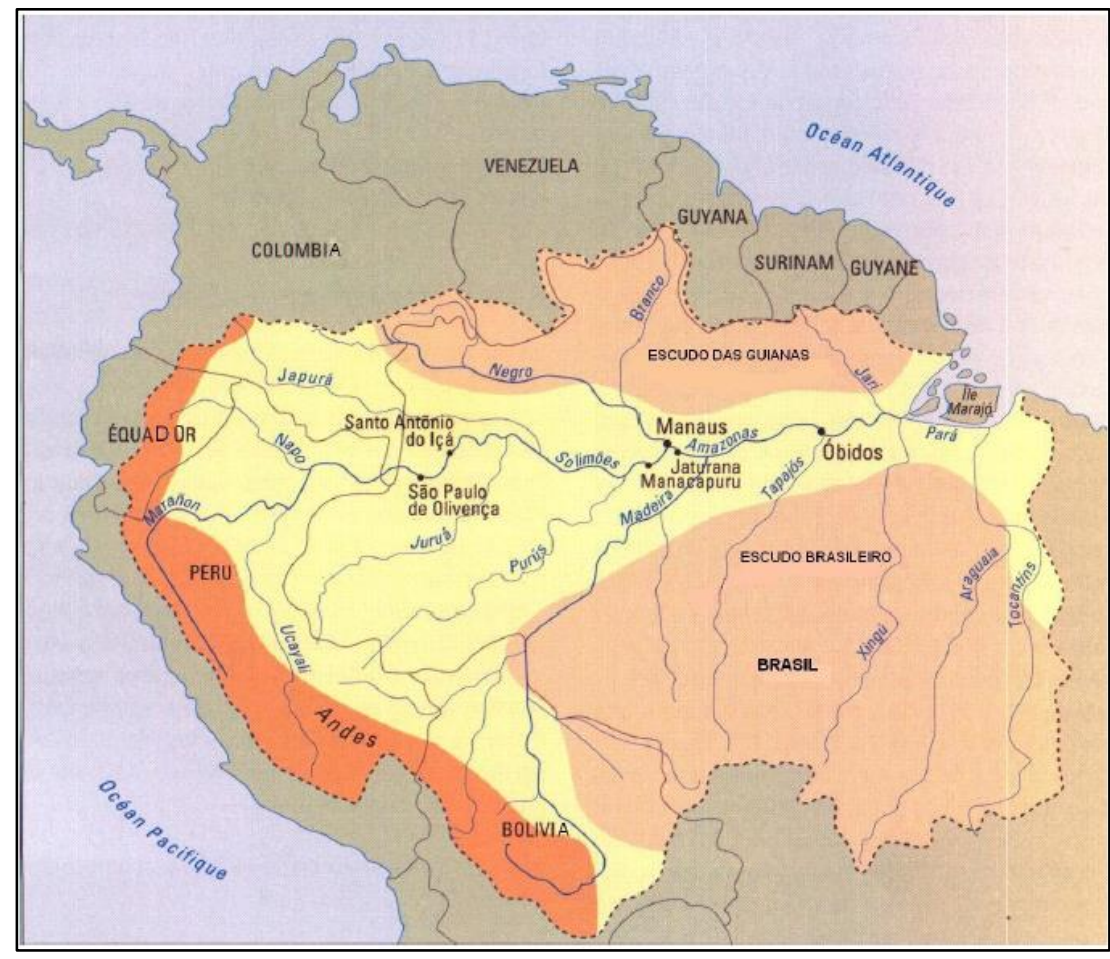

Figura 2 - Limites geomorfológicos (atuais) da Bacia Amazônica. (Fonte: Amorim, 2006).

Há cerca de 130 milhões de anos a nascente do antigo rio Amazonas estaria localizada na África, no nordeste do atual Tchad. Nessas condições o rio corria na direção inversa, de leste para oeste, e desaguava no oceano Pacífico. Com a separação do supercontinente Pangeia, mais particularmente do Gondwana, na Era Mesozoica, houve a separação dos continentes da América do Sul e África e o início da formação do Oceano Atlântico. O deslocamento da placa SulAmericana fez com que essa colidisse com a placa de Nazca. A placa de Nazca deslizou sob a placa Sul-Americana, empurrando-a para cima e formando assim a Cordilheira dos Andes durante o Plioceno (Putzer, 1984). Ao mesmo tempo, começava a erguer-se no meio da Bacia Amazônica um maciço de baixas altitudes, que dividiu o curso do rio (Arco de Purus). Na região onde hoje está soerguida a Cordilheira dos Andes, era encontrado um imenso sistema de lagos (Lago Pebas) que cobria toda a região amazônica oriental e tinha uma possível conexão com o mar (Portão de Guayaquil). Os rios que drenavam o recém-soerguido Andes despejavam seus materiais nesse lago, transportando grandes quantidades de sedimentos, formando assim as 
planícies aluviais e criando um dos maiores sistemas lacustre pantanoso que a Terra presenciou (Rasanen, 1988; Amorin, 2006).

Com o soerguimento definitivo dos Andes, houve o fechamento do "Portão de Guayaquil”, a erosão do divisor de água (Arco de Purus) e a junção das águas de forma que a partir desse momento os rios da região amazônica transportam suas águas para leste, depositando sedimentos ao longo da bacia e desembocando no oceano Atlântico (Figura 3).

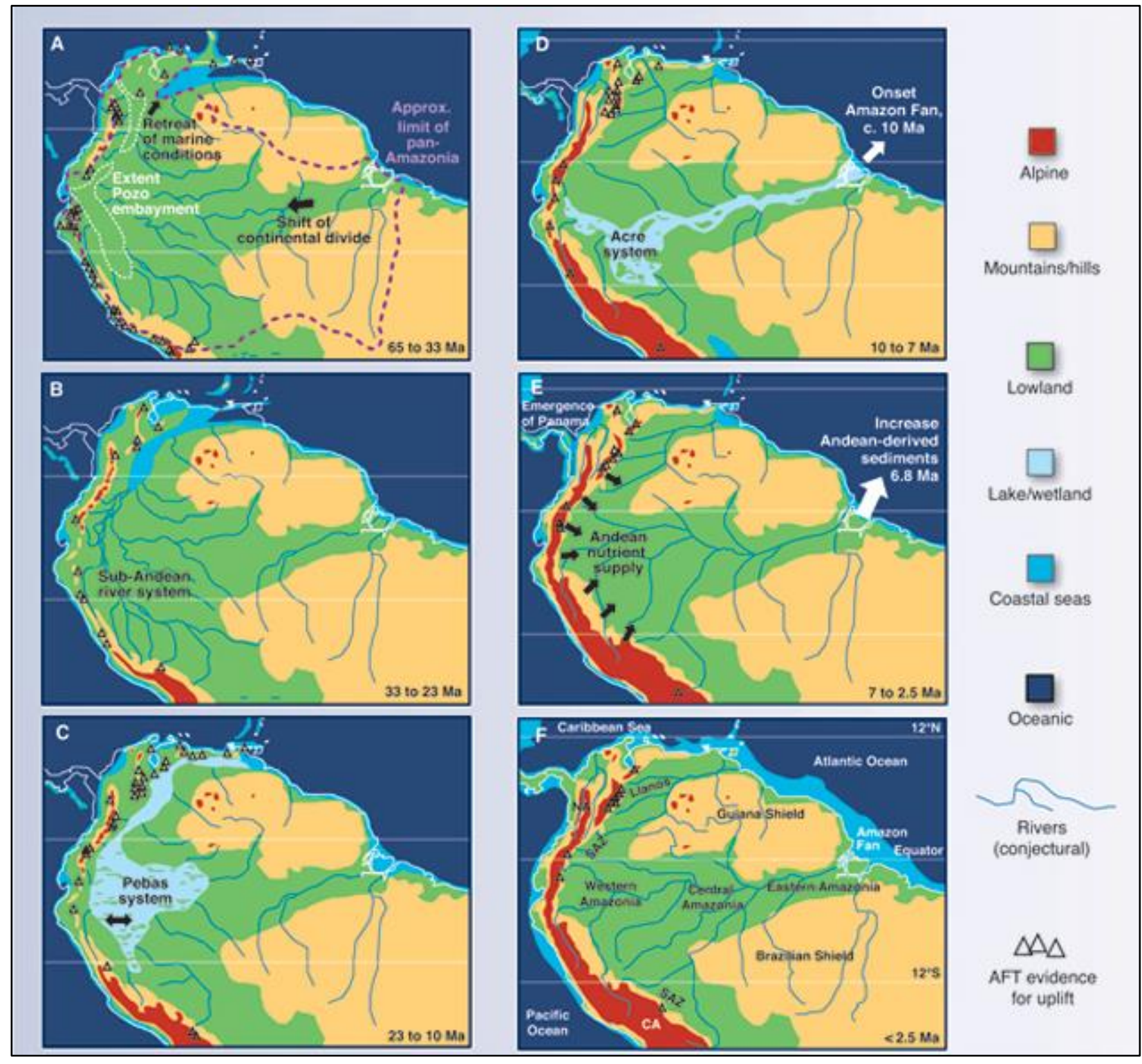

Figura 3 - Modelo simplificado da evolução interna da Bacia Amazônica. As figuras acima (de A a F) retratam as mudanças ocorridas na Bacia Amazonica no intervalo de 65 milhões de anos a 2,5 milhões de anos atrás com o soerguimento da Cordilheira dos Andes - em vermelho. Imagens: Science- joaquimnery .files. wordpress. com_ 2015_05_ biodiversidadeamazonia 03 ).

Segundo Putzer (1984), durante as de glaciações no Pleistoceno, a descida do nível do mar fez com que os rios da região amazônica deslocassem suas massas de água com uma maior velocidade devido ao desnível gerado, fazendo com o que os seus leitos sofressem maiores taxas 
de erosão, carreando esse material sedimentar para fora do sistema. Um novo aumento do nível do mar, de 18.000 a 6.000 anos fez com que esse desnível se normalizasse e em consequência disso o sedimento carreado dos Andes voltou a se depositar na Bacia Amazônica, gerando a paisagem atual (Putzer, 1984, Amorim, 2006).

\subsubsection{Geologia}

Baseada na estrutura geológica, a bacia Amazônica pode ser identificada por três unidades geológicas: Escudos Cristalinos, Cordilheira dos Andes e cobertura sedimentar de caráter flúvio-lacustre (Amorim, 2006).

Escudos Cristalinos: são compostos por rochas formadas, em sua maioria, durante o Pré-Cambriano, bastante erodidas com relevo muito pediplanizado e nivelado. O Escudo das Guianas é caracterizado por ondulações suaves seguidas de montanhas próximas a fronteira com a Venezuela. Já o Escudo Brasileiro é caracterizado por superfícies onduladas de baixo relevo, já bastante erodidas (Figura 4) (Putzer, 1984).

$>$ Cordilheira dos Andes: é originária do choque das placas de Nazca e SulAmericana, apresenta rochas sedimentares, vulcânicas e metamórficas. Possui relevo bastante elevado e acidentado. Contribuiu fortemente para a formação da bacia Amazônica e é ainda hoje uma grande fonte de sedimentos para a bacia (Figura 4) (Guyot et al. 1992).

> Planície sedimentar Amazônica: a planície sedimentar da Amazônia apresenta baixa declividade. Sua composição vem essencialmente de material rochoso (sedimentar e magmático) erodido nos Andes e dos escudos cristalinos. Sua região superficial apresenta períodos em que é temporariamente alagada e terraços pleistocênicos formados em períodos em que o nível da água dos rios estava maior que o atual (Figura 4) (Putzer, 1984). 


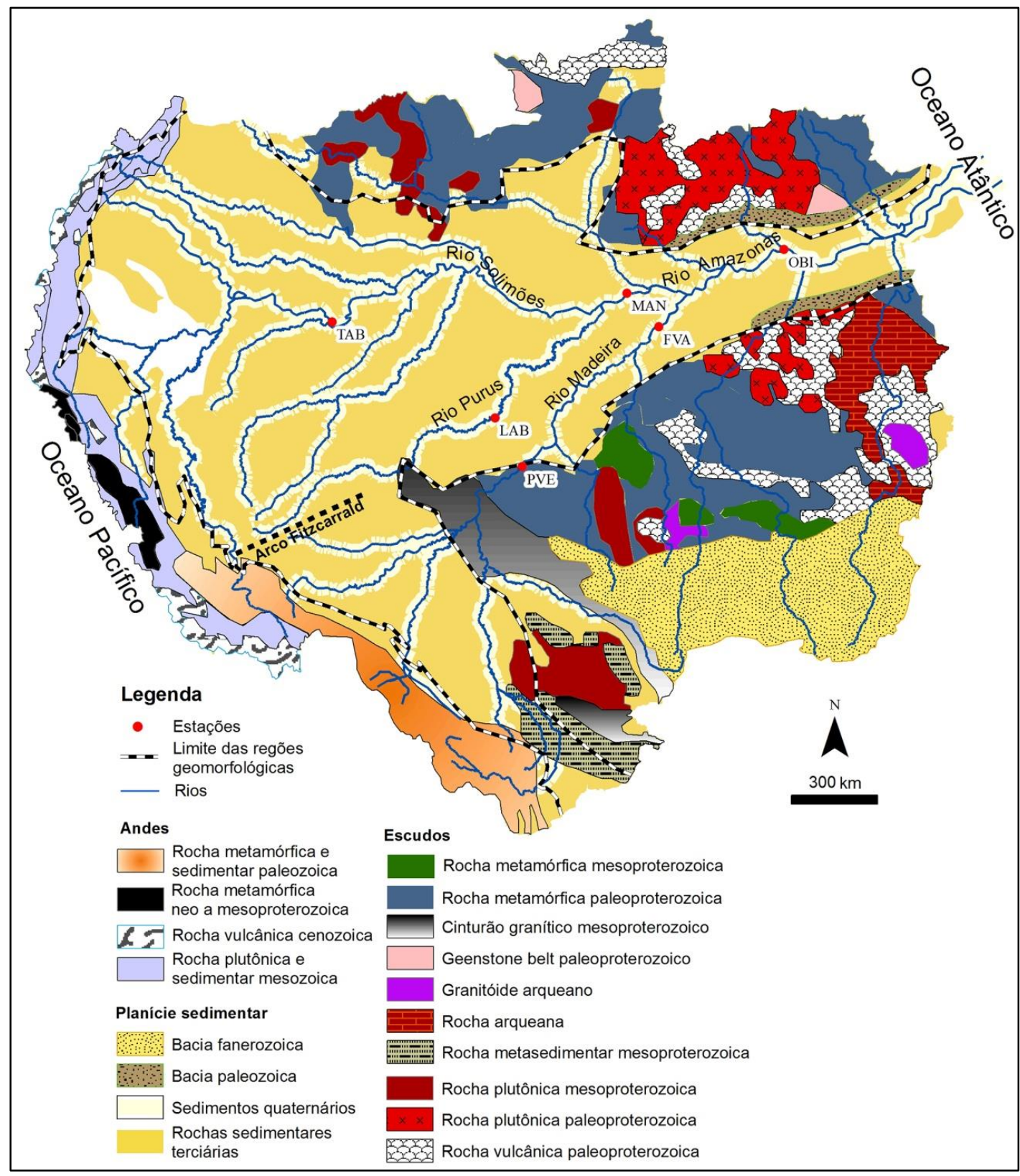

Figura 4 - Mapa geológico da bacia Amazônica. Fonte: Clim Amazon (http://www.climamazon.eu/content/view/full/51654) (modificado SANCHEZ et al., 2015).

\subsubsection{Geomorfologia}

De acordo com a classificação de Jurandyr Ross (1990), é possível classificar o relevo amazônico em ordem crescente de altitude (Figura 5):

Planície do Rio Amazonas- Abrange uma estreita faixa de terras planas que acompanha os rios Amazonas, Solimões, Purus, Juruá, Javari e Madeira com altitude inferior a $100 \mathrm{~m}$.

Depressão da Amazônia Ocidental - Abrange a maior parte da região com altitudes de 100 à 200 m.

Depressão Marginal Norte Amazônica - Apresentam altitudes de 200 a 300 m. 
Depressão Marginal Sul Amazônica - Também apresenta altitudes com variação de 200 a $300 \mathrm{~m}$.

Planalto da Amazônia Oriental - É a superfície com altitude de 400 a 500 metros, recoberta por mata densa, compreende terras que vão de Manaus até o Oceano Atlântico.

Planaltos residuais Norte Amazônicos - São as superfícies de maior altitude da região, variando entre 800 a 1.200 m. O Pico da Neblina e o Pico 31 de Março são os pontos culminantes do relevo brasileiro, ambos na Serra do Imerí, fronteira entre Amazonas e Venezuela.

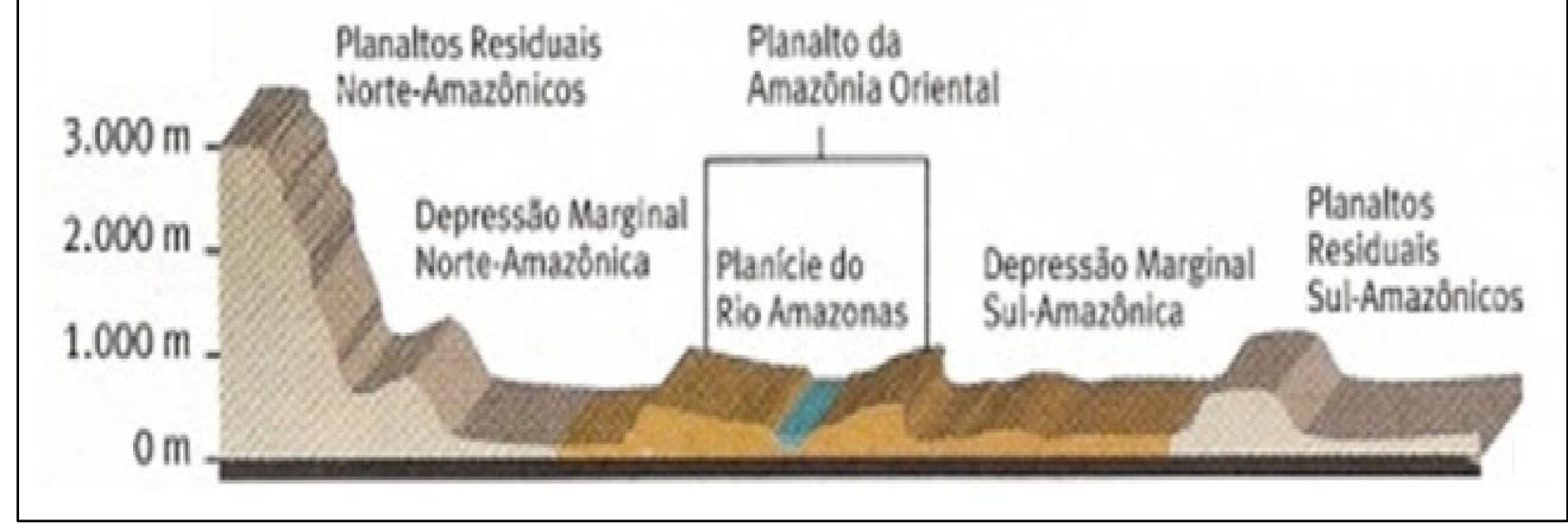

Figura 5 - Modelo esquemático de um perfil Norte-Sul (NW-SE) na Bacia Amazônica (ROSS, 1990).

\subsection{Pedologia}

Como já mencionado na Introdução, a Bacia Amazônica apresenta uma grande diversidade de tipos pedológicos, mas há dois tipos de solos que ocupam a maior parte da bacia:

Os latossolos são os solos mais comuns na Bacia Amazônica, cobrindo cerca de $45 \%$ de sua área total; a maioria da área restante está coberta por argissolos, perfazendo uma área de aproximadamente 30\% da bacia (Cochrane e Sánchez, 1982; Demattê, 1988).

Os latossolos ocorrem praticamente em todo o país e se desenvolvem sobre todos os tipos de rocha. São solos com baixa capacidade de troca de cátions, com presença de argilas de baixa atividade, geralmente muito profundos (mais de $2 \mathrm{~m}$ ), evoluídos, bem drenados (com taxas de infiltração normalmente alta, ' $\mathrm{Kv}=10^{-3}$ a $10^{-5} \mathrm{~m} / \mathrm{s}$ ') e de cor amarela a vermelho-escura (dada pela variação na concentração de óxidos e hidróxidos de ferro e alumínio), localizados em terrenos planos ou pouco ondulados. São típicos de regiões de clima tropical úmido e semiúmido e muito utilizados para a agricultura. 
Os argissolos também ocorrem em locais com diferentes condições climáticas e diferentes materiais de origem. Sua ocorrência está relacionada, em sua grande maioria, a paisagens de relevos mais acidentados e dissecados, com superfícies menos suaves. São caracterizados por horizontes de acumulação de argila e propriedades físicas menos favoráveis para a agronomia.

Na Amazônia a maioria desses solos são derivados de depósito sedimentares formados devido ao ambiente marítimo-lacustre que ocupou o centro da bacia durante o Terciário (Falesi, 1974; Daemon, 1975; Jordan 1985; Horbe et al., 2003), e compõem a Formação Alter do Chão. Os solos derivados destes sedimentos foram expostos ao clima tropical ao longo de milhões de anos, desde que a região foi drenada pelo efeito da elevação dos Andes; com isso, a maioria dos nutrientes dos solos foram lixiviados (Sombroek, 1984).

Nas margens dos rios são encontrados solos mais férteis - nas várzeas; nelas são acumulados nutrientes trazidos pelas águas em períodos de cheias, vindos especialmente de áreas próximas à Cordilheira dos Andes. É possível observar em alguns lugares a presença de terra roxa (com destaque para os estados de Rondônia e Acre) e outros solos de forma mais restrita e de repartição local, controlados pelas condições edáficas, como organossolo, plintossolo e neossolo flúvico.

Com a crescente ocupação humana na Bacia Amazônica várias áreas de floresta foram desmatadas para a implantação de áreas agrícolas. As atividades de manejo agrícola ao redor das florestas remanescentes aplicam produtos e técnicas visando o aumento de produção, mas que gradualmente desgastam o solo. A ausência da manutenção de pastos, as queimadas e o desmatamento de áreas de floresta buscando o aproveitamento da camada superficial do solo para criação de roças são exemplos de atividades que alteram o estado de equilíbrio da cobertura vegetal e pedológica, o que acaba resultando no empobrecimento do solo e em mudanças de suas características superficiais, facilitando os processos de erosão e influenciando nos processos de transferência de matéria na região (Raffles, 1999; Elbaz-Poulichet et al., 1999; Ab' Saber, 2005, Amorim, 2006).

Demattê et al. (1993), realizou um estudo sobre as propriedades químicas de solos das regiões da floresta amazônica e do cerrado do Brasil central. Nesse estudo foram levantados dados de 17 perfis de solos da região do Triângulo Mineiro e de 76 perfis de solo do Pará até o Acre. Foi observado que os solos da região do Cerrado são mais intemperizados do que os da região Amazônica, havendo dominância de mineralogia oxídica, e mais estáveis do que a dos solos da região Amazônica, onde a mineralogia é caulinítica com contribuição de minerais 2:1. Apesar disso, a capacidade de troca catiônica (CTC) dos latossolos da Amazônia não difere da CTC dos solos de cerrado. Demattê et al.(1993), observou também que à medida que a 
profundidade do solo aumenta, o teor de carbono orgânico da região do cerrado mostra-se superior ao dos solos da região Amazônica, isto é válido para os solos de textura argilosa e muito argilosa. O teor de carbono orgânico na faixa de 0-100 cm é de 4,2\% na região Amazônica, contra 5,8\% na região de cerrado para os solos com teor de argila acima de 60\%. Já nos solos de textura média a arenosa, o teor de carbono orgânico dos solos da Amazônia é sempre superior ao da região do cerrado, independentemente da profundidade. Os resultados obtidos, não deixam de surpreender, pois, tende-se a considerar que os solos da região do cerrado tem baixo teor de matéria orgânica (Lopes, 1983; Malavolta; Kliemann, 1985), e os da região Amazônica, como tendo elevado teor (Sanchez, 1976; Vieira e Santos, 1987). Lucas et al. (1993) afirma que devido a alta taxa de reciclagem de matéria nos solos da Amazônia apenas os primeiros centímetros do perfil de solo apresentam grandes valores de carbono orgânico.

Lucas et al. (1993) também estudaram a relação entre as atividades biológicas da Floresta tropical e a composição mineral do solo e afirmaram que o solo dessa região é composto basicamente por quartzo e caulinita, e em menores quantidades por gibbsita e goetita. Segundo Lucas et al. (1993), este arranjo mineralógico não pode ser produzido simplesmente pela lixiviação. Os resultados obtidos sobre estudos da reciclagem dos elementos no ecossistema amazônico indica que a floresta (vegetação) recicla uma quantidade significativa de elementos, sobretudo de silício. Este efeito mantém o silício no limite da lixiviação para horizonte mais profundo e pode contribuir para a estabilidade da caulinita nos horizontes superiores do solo. A composição mineral do solo é, portanto, mantida pela ação conjunta da lixiviação e atividade biológica (Lucas et al., 1993).

Martins et al.(1990), estudaram o efeito do desmatamento e do cultivo sobre características físicas e químicas do solo sob floresta natural na Amazônia Oriental. A área de estudo localiza-se no Pará sobre latossolos amarelos de textura média, plintossolos, gleissolos hidromórficos e latossolos amarelos podzolizados (Rego et al., 1973). De forma simplificada eles observaram que com o aumento do tempo de cultivo, a espessura do horizonte A decresce. Os resíduos vegetais da superfície do solo desaparecem rapidamente, e o conteúdo de carbono orgânico do solo decresce $14 \%$ em todo o perfil, e $24 \%$ na camada 0-20 cm, após cinco anos de cultivo. Marques et al. (2012) realizaram um estudo sobre as variações do carbono orgânico dissolvido e de atributos físicos do solo sob diferentes sistemas de uso da terra na amazônia central e corroboram os dados levantas por Martins et al. (1990).

Oliveira et al. (2011), realizaram estudos sobre o comportamento da taxa de infiltração de água no solo em área de floresta tropical. A pesquisa foi realizada na Reserva Florestal de Caxiuanã - PA. Os resultados mostraram que, a partir dos valores obtidos em campo, a 
velocidade de infiltração de água no solo apresenta relação inversamente proporcional a precipitação pluviométrica. Essa pesquisa mostra que, quanto mais seco é o solo, maior é a velocidade de infiltração e maior o volume potencialmente infiltrado de água no solo, podendo proporcionar mudanças no ciclo de vida da floresta. Mais recentemente, Riquelme et al. (2012), ressaltou em suas pesquisa dados semelhantes aos encontrados por Oliveira et al. (2011).

\subsection{Vegetação e Clima}

O território brasileiro encontra-se quase todo na zona tropical e tem um relevo que desde o final do Cretáceo não sofreu grandes movimentações. Assim, a natureza da rocha e o relevo tem importância secundária na formação dos solos, sendo o clima e a vegetação importantes fatores na pedogênese (Amorim, 2006).

\subsubsection{Clima}

O clima da região amazônica é quente e úmido, com temperatura média anual em torno de $26,6^{\circ} \mathrm{C}$; a taxa de umidade relativa do ar permanece alta durante o ano todo, variando entre 75,6 e 86,7\% (Salati e Marques, 1984). A Bacia Amazônica está submetida a um regime de precipitações essencialmente de origem atlântica e recebe em média $2.460 \mathrm{~mm} / \mathrm{ano}$. Na parte brasileira da bacia, a distribuição sazonal das precipitações demonstra diferenças sensíveis entre o Norte e o Sul. Ao Norte do Equador (bacia do Rio Negro), o máximo pluviométrico é observado de maio a julho, enquanto que ao Sul da bacia, de dezembro a março. A metade do volume das precipitações retorna à atmosfera em forma de vapor d'água devido à evapotranspiração da floresta amazônica (Molinier et al., 1994). De forma geral o período chuvoso na região inicia-se na parte oeste do Amazonas e avança até o leste. Como o rio flui nesta mesma direção, o aumento do nível de água não é sincronizado com a precipitação local. É possível observar uma oscilação anual do nível de água de cerca de dez metros entre a época seca e cheia (Fisher e Parsley, 1979; Molinier et al., 1994; Irion et al.,1997; Moreira-Turcq et al., 2003; Amorim, 2006; Salcedo, 2011).

\subsubsection{Vegetação}

A extensão da floresta Amazônica é de aproximadamente 5,5 milhões de $\mathrm{km}^{2}$. A Amazônia corresponde a cerca de um terço das florestas tropicais e apresenta cerca de $10 \%$ da biota de todo o planeta (Keddy et al., 2009).

Os principais tipos de floresta observados na Amazônia são (Figura 6):

Floresta de Terra Firme: Ocupam a maior parte da região e não são inundadas pelas cheias dos rios. É uma formação densa, úmida e escura (a copa das árvores forma um telhado que pode reter até $95 \%$ da luz solar). Por localizarem-se em solos extremamente 
empobrecidos em nutrientes, isto forçou uma adaptação das raízes das plantas, que, através de uma associação simbiótica com alguns tipos de fungos, passaram a decompor rapidamente a matéria orgânica depositada no solo, a fim de absorver os nutrientes antes deles serem lixiviados.

Florestas de Várzea: Correspondem a segunda maior formação vegetal da bacia Amazônica. São áreas de inundação temporária, normalmente por águas classificadas como águas brancas e possuem composição vegetal variável.

$>$ Florestas de Igapó: Ocorrem em áreas que permanecem alagadas a maior parte do ano. As árvores raramente perdem suas folhas e possuem raízes respiratórias, as quais possuem poros que permitem a absorção de oxigênio atmosférico. Essas áreas normalmente são banhadas por águas escuras.

Caatingas e Cerrado: são caracterizadas pela presença de árvores mais baixas, espaçadas, com troncos finos e tortos. Esta vegetação é típica de solos lixiviados (Amorim, 2006; Keddy et al., 2009).

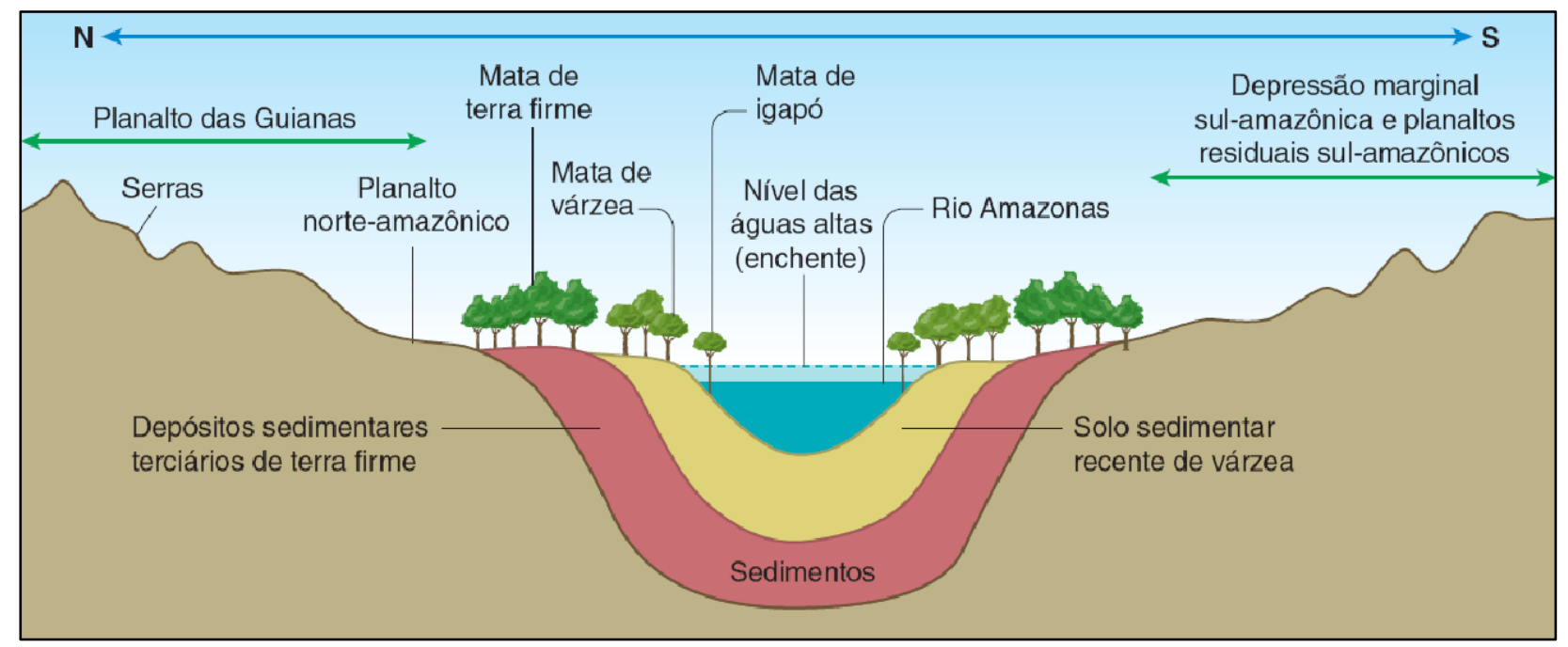

Figura 6 - Perfil esquemático do relevo da Bacia Amazônica e disposição representativa da vegetação nas proximidades da área de estudo (Fonte: http://marcosbau.com.br/wp-content/uploads/2010/05/degraus-amazonia1.png).

\section{5 - Hidrologia e Sistema de Várzeas}

A Bacia Amazônia representa uma mistura de águas provenientes de várias fontes. As águas "brancas" (turvas), originadas dos Andes, possuem alta concentração de material em suspensão (MES), e apresentam pH neutro a básico (6,2-7,2), alcalinidade elevada e alto teor de nutrientes. Os rios de água "preta" (transparentes, mas de cor marrom) como o rio Negro, originadas nas partes baixas da planície amazônica possuem águas ricas em matéria orgânica, que tendem a ser ácidas, de baixa alcalinidade (pH 3,8-4,9) e com baixo teor de nutrientes. As águas “claras" (transparentes) como rio Tapajós e o Xingu possuem baixa concentração de sólidos em suspensão, pH instável $(4,5-7,8)$ e quantidade bastante variável de nutrientes, em função do solo 
da bacia em que estão inseridas (Sioli, 1984; Junk et al., 1989; Goulding, 1993; Junk, 1997b ; Piedade et al., 2010; Salcedo, 2011).

Por se localizarem em regiões planas, marginais ao rio, as várzeas são compostas por lagos temporários e lagos permanentes interconectados e conectados ao curso principal do rio (Irion et al., 1997). Estes sistemas são periodicamente inundados pelo transbordamento lateral de rios ou lagos, pela precipitação direta, pelo escoamento superficial das bacias de drenagem ou pela infiltração das águas subterrânea (Junk, 1997b).

As características físico-químicas das águas dos lagos de várzea são dependentes das propriedades do solo e da geologia de sua bacia de drenagem e são modificadas, principalmente, sob a influência dos processos sedimentares e biogeoquímicos que ocorrem nas planícies de inundação (Junk, 1997a; Richey et al., 1989; Wilson et al., 2007). As características físicoquímicas próprias de lagos de várzea tornam-se mais evidentes quando observadas nos baixos níveis das águas, durante o período de seca, onde a variabilidade na qualidade e quantidade do material em suspensão liberados principalmente dos sedimentos acumulados no fundo dos lagos de várzea é menor (Barroux, 2006; Trevisan e Forsberg, 2007). Entretanto, no período de cheia, as características físico-químicas das águas dos lagos de várzea recebem uma grande influência dos rios principais devido à sua proximidade (Sioli, 1957; Sioli, 1984; Salcedo, 2011).

De acordo com as propriedades físico-químicas das águas, as planícies de inundação brasileiras são classificadas em dois grandes grupos: as várzeas, cobrindo aproximadamente $200.000 \mathrm{~km}^{2}$ da região amazônica brasileira, e os igapós que cobrem, aproximadamente, uma área de $100.000 \mathrm{~km}^{2}$ da região. Os rios associados às várzeas e igapós tem respectivamente águas "brancas" e "pretas" ou "claras" (Piedade et al., 2010).

O regime hidrológico da bacia Amazônica é do tipo monomodal, ou seja, possui um pico anual, e apresenta quatro fases distintas: enchente, cheia, vazante e seca (Figura 7). Durante o período de enchente há o aumento do nível da água do rio, quando essas águas começam a inundar as planícies de inundação, há um incremento na entrada de material orgânico e inorgânico (dissolvido e suspenso) provenientes do rio principal à planície de inundação (como sedimentos carreados dos Andes e escudos cristalinos, matéria orgânica). Habitats terrestres são inundados, grandes quantidades de biomassa se decompõem e a matéria orgânica e inorgânica depositada durante a fase terrestre é espalhada pela planície na subida da água. Com a estabilização do nível de água, durante a cheia, tem-se a deposição de parte dos sedimentos e nutrientes em suspensão (Tockner et al., 2000). Na vazante, com a diminuição do nível de água, os nutrientes se concentram, contribuindo para as mudanças químicas na água e nos solos (Figura 7). 


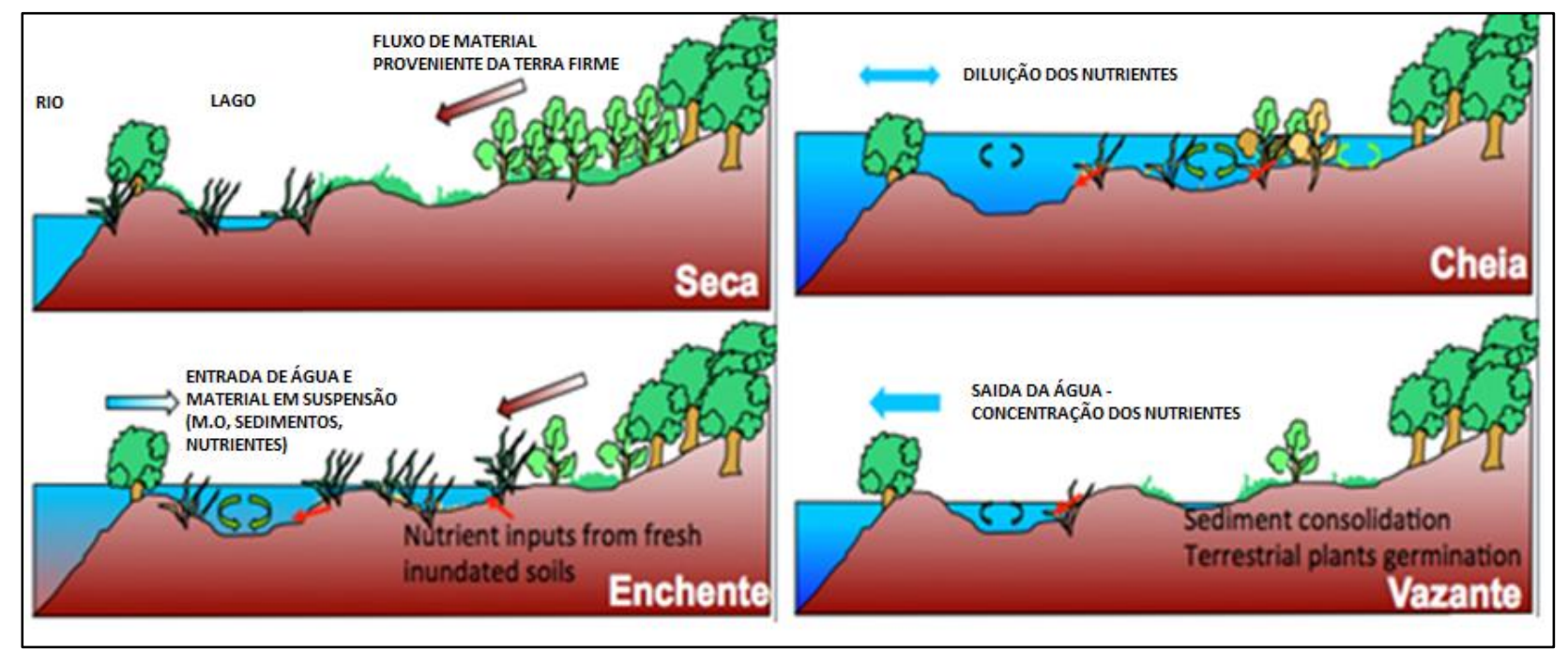

Figura 7 - Representação das interações água/materiais que ocorrem na Várzea (Junk et al. 1989).

Os ambientes de várzea no Amazonas estão entre os mais ricos e produtivos do mundo. Os pulsos de inundação favorecem a reciclagem rápida da matéria e a existência de vários microhabitats, explicando as altas produtividades e biodiversidade das várzeas - esses pulsos são capazes de alterar a qualidade da água que transita pelas várzeas e modificar as propriedades hidráulicas e químicas do solo. 


\section{3- Área de Estudo: Várzea do Lago Grande de Curuai}

\section{1 - Localização}

A várzea do Lago Grande de Curuai (Pará) está localizada na margem direita do curso principal do Rio Amazonas, próximo à cidade de Óbidos, a aproximadamente $850 \mathrm{~km}$ a montante da foz no oceano Atlântico, abrangendo os municípios de Óbidos, Juruti e Santarém no estado do Pará (Figura 8) (Moreira-Turcq et al., 2004). Segundo Amorim (2006), essa região possui um área total superior a $7.000 \mathrm{~km}^{2}$.

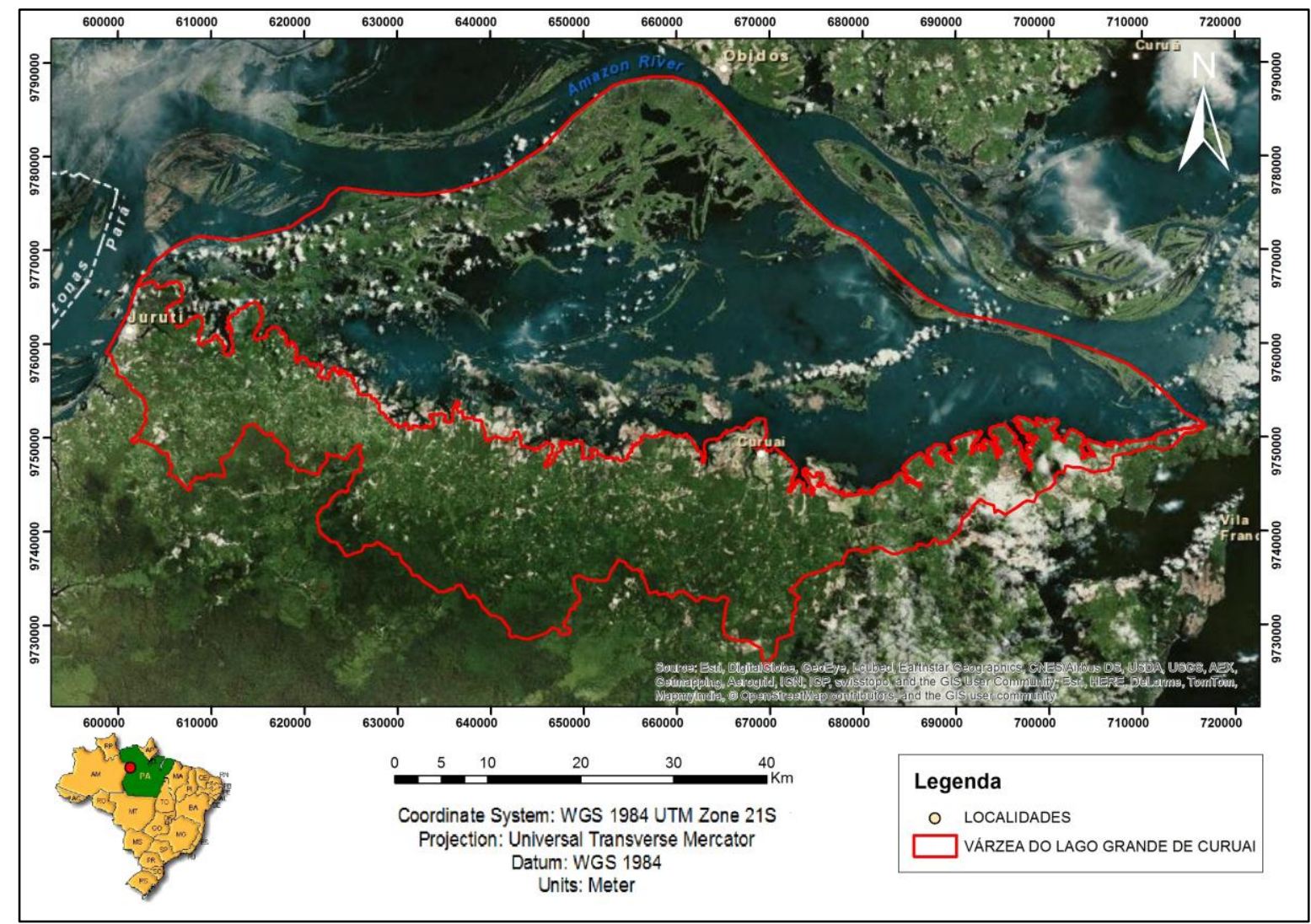

Figura 8 - Localização da área de estudo - destacada em contorno vermelho os limites da bacia hidrográfica. A porção norte representa a área periodicamente alagada (zona de várzea), o contorno sul representa a área de terra firme, que dificilmente é alagada.

\section{2 - Geologia}

A zona de estudo apresenta uma litologia correspondente à Formação Alter do Chão, Cretáceo (Lucas, 1989; Cunha et al.1994). Esta Formação é constituida por arenitos arcoseanos, pelitos, argilitos, arcóseos, quartzo-arenitos e brechas intraformacionais sob a forma de estratos esbranquiçados a avermelhados, depositados em ambiente flúvio-lacustre (depósitos sedimentares do Terciário).

Abaixo é apresentado um mapa geológico da área que foi elaborado com base na base de dados do IBGE e da CPRM (Figura 9). 


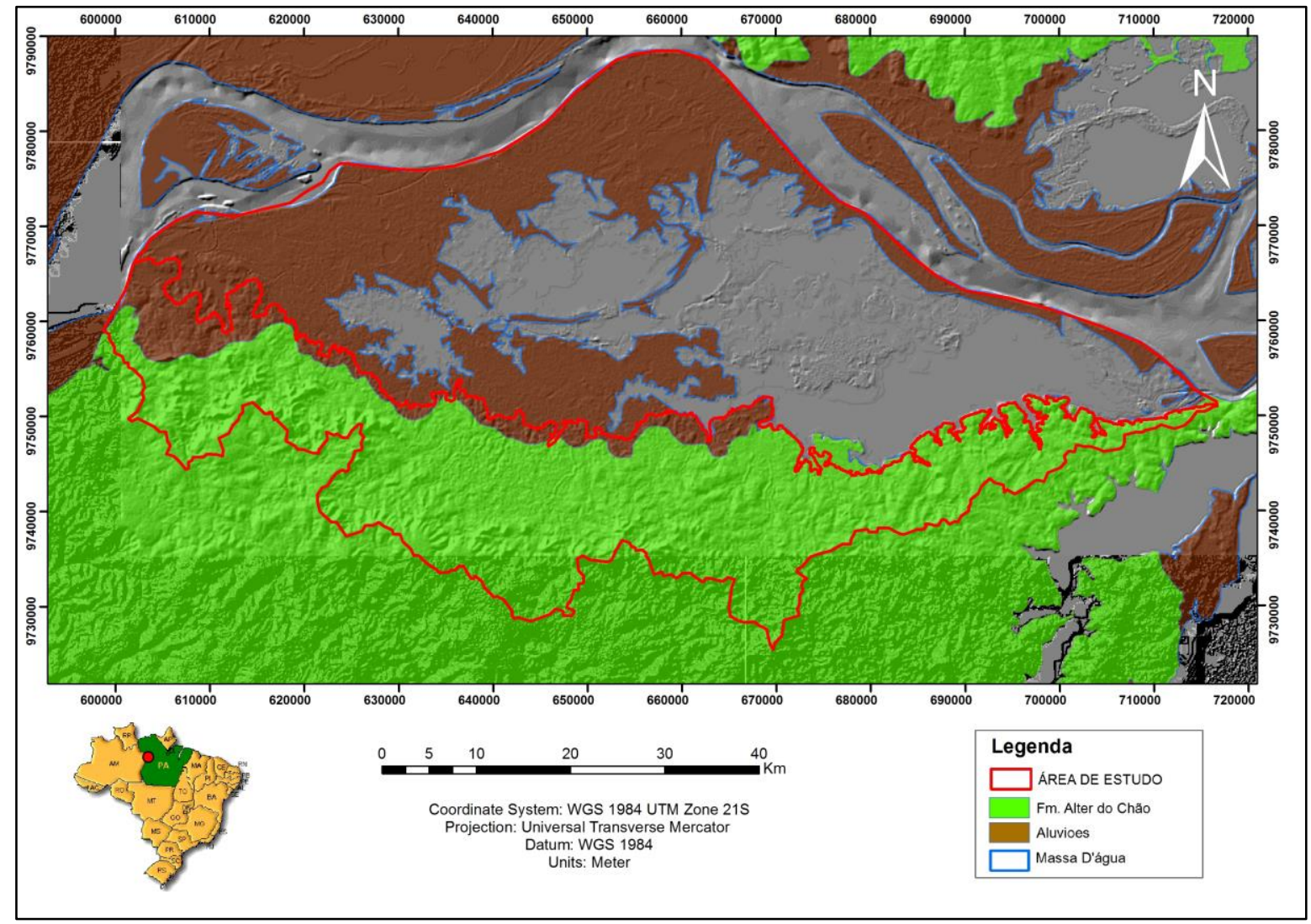

Figura 9 - Mapa geológico da área feito a partir da base de dados do IBGE e CPRM sobreposto a compilação das cartas de relevo: SA-21-Z-A, SA-21-Z-B, SA-21-Z-C e SA-21-Z-D retiradas da base de dados da EMBRAPA e trabalhadas com a ferramenta hillshade do Arcgis 10. Os limites da área de estudo estão delimitados pela linha de cor vermelha.

O segmento sul da área de estudo (porção de terra firme) é marcado quase que inteiramente por arenitos de granulometria média a grossa da Formação Alter do Chão - e alguns argilitos, já no segmento norte, (porção da área constantemente alagada - zona de várzea) são observados depósitos de aluvião recentes de granulometria variável - areia grossa a argila. Ao longo da linha de transição que separa a porção norte da porção sul da área é possível observar a intercalação das duas litologias (Figura 9).

\subsection{Pedologia}

Segundo dados da EMBRAPA, a área de estudo está associada a latossolos (predominantemente latossolos amarelo distróficos), e gleissolos háplicos. Esses solos apresentam baixa fertilidade natural, grau relativamente avançado de intemperismo e presença de caulinita como principal mineral da fração argila, além de limitações físicas dos solos para uso agrícola (EMBRAPA, 1982a e 1982b; Vale Júnior, 2000; Melo, 2002; Melo et al., 2006; Benedetti et al., 2011). Uma compilação entre a base de dados da EMBRAPA e do IBGE revela que a área de estudo é composta basicamente por latossolos amarelo na zona de terra firme e por 
gleissolos háplicos na zona alagada; infelizmente esse dados são apenas inferidos pois não contam com pontos pedológicos na área de estudo para confirmar a informação (Figura 10).

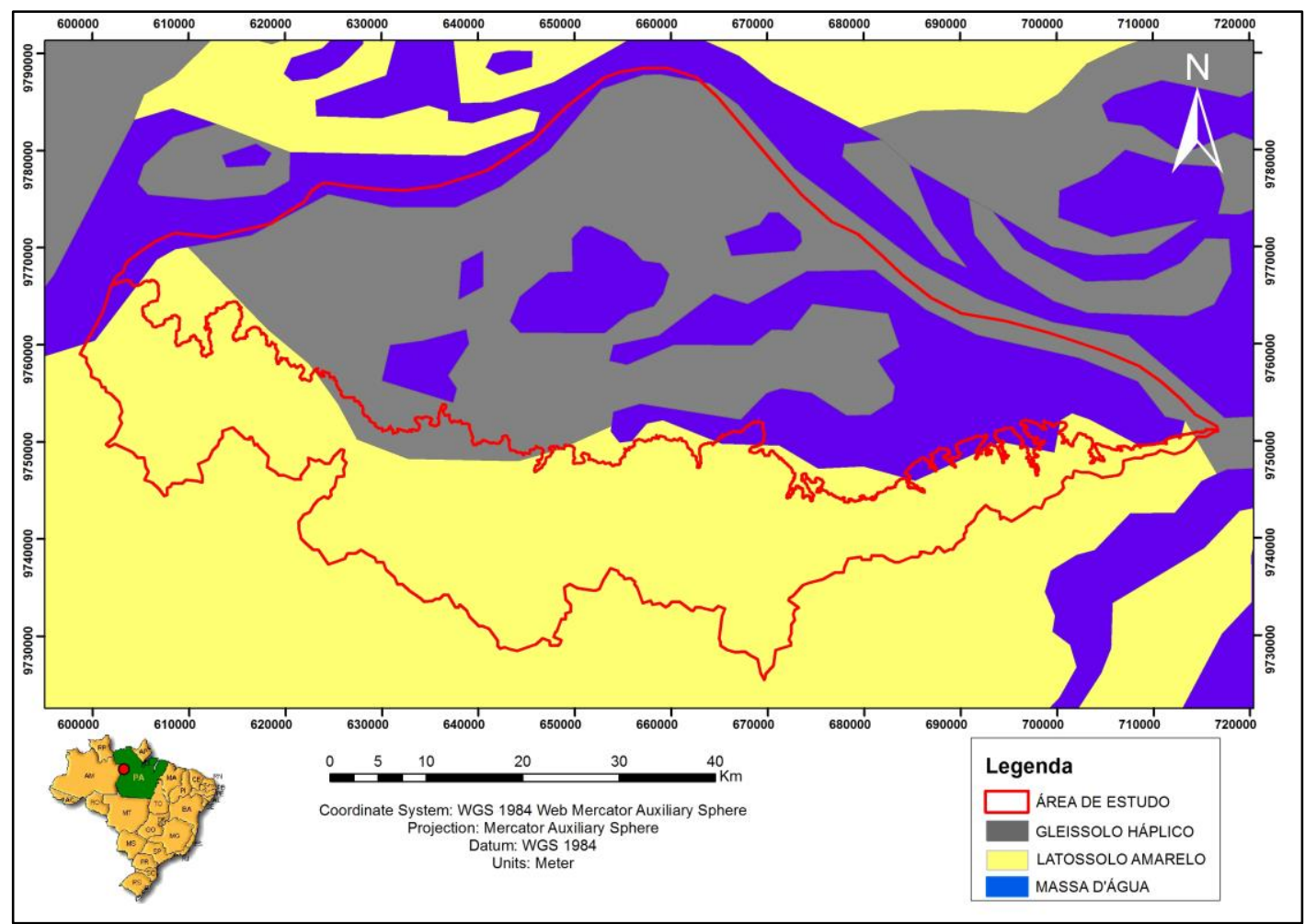

Figura 10 - Mapa pedológico da área de estudo (gerado no Arcgis 10.1 a partir da Base de Dados da Embrapa e do IBGE).

De acordo com Cunha et al. (1994) a região apresenta paleossolos avermelhados de espessura entre 10 e 20 metros, constituídos principalmente por depósitos aluviais recentes e compostos de óxido-hidróxido de ferro. Os oito metros superficiais são essencialmente formados por quartzo, goetita, caulinita e ilita. Este solo é submetido a um regime de alteração (intemperismo) muito forte, e a caulinita é o mineral mais importante da fração argila. Nos horizontes mais profundos ( mais que oito metros de profundidade), Irion (1984) apresenta a possibilidade de neoformação de montmorilonita pela dissolução de minerais de potássio (micas e ilitas).

Latossolo Amarelo: Segundo as informações da 'Agência EMBRAPA de Informação Tecnológica' (ageitec), os Latossolos Amarelos são solos bastante uniformes em termos de cor, textura e estrutura ao longo de todo o perfil; são profundos (superior a dois metros de profundidade), bem drenados, com predominância de textura argilo-arenosa. Estão associados predominantemente a um relevo plano a suave ondulado. Apresentam sequência de horizontes A e Bw (horizonte B latossólico), com predomínio do horizonte superficial do tipo A moderado e proeminente e, raramente do tipo húmico; apresentam baixa fertilidade natural e baixa soma de bases. 
> Gleissolo Háplico: Segundo os dados da 'ageitec' são solos minerais, hidromórficos, apresentando horizontes A (mineral) ou H (orgânico), seguido de um horizonte de cor cinzento-olivácea, esverdeado ou azulado, chamado horizonte glei, resultado de modificações sofridas pelos óxidos de ferro existentes no solo (redução) em condições de encharcamento durante o ano todo ou parte dele. O horizonte glei pode começar a $40 \mathrm{~cm}$ da superfície. São solos mal drenados, podendo apresentar textura bastante variável ao longo do perfil.

\section{4 - Vegetação}

A área de estudo pode ser divida em dois grandes sistemas de paisagens: i) áreas de inundação - várzea; e ii) áreas de inundação inexistente ou moderada - zona de terra firme e zona de transição).

Dentro da várzea, há vários tipos de paisagens presentes. Porém essas paisagens seguem o ciclo sazonal hidrológico do nível da água.

Na estação chuvosa, as áreas inundadas tem a sua vegetação alagada, onde parte morre e se decompõe, formando os detritos orgânicos, fonte de alimento dos peixes; parte da vegetação funciona como substrato ou filtro que retém os sedimentos e matéria orgânica dissolvida, servindo como substrato para desenvolvimento de algas e micro-organismos animais.

$\mathrm{Na}$ fase seca, há novamente todo o crescimento da vegetação nas áreas anteriormente alagadas, devido ao material enriquecido (em nutrientes, matéria orgânica, argilas 1:1 e 2:1) depositado após a descida das águas, assim como pela decomposição da vegetação presente antes da subida das águas. Dessa forma, o sistema consegue incorporar e aproveitar matéria orgânica de forma eficiente, influenciando na diversidade ambiental. Esta alternância de ambiente permite uma rápida renovação. A vegetação típica dessa área é formada por pastagens naturais que durante o período de seca da bacia são usadas para criação de animais, principalmente cavalos, gado e búfalo (Viers et al., 2005; Martinez e Le Toan, 2007).

Nas áreas de inundação inexiste ou moderada o solo apresenta uma cobertura vegetal típica de floresta tropical e/ou caatinga. Essa parte da região de estudo é ocupada de acordo com um gradiente de vegetação, que vão de áreas de pastagens naturais à formação de florestas com altura das árvores de aproximadamente dez metros. São classificados quatro tipos de ocupações vegetais para essa zona: i) pastos naturais; ii) zonas compostas por pouca vegetação arbustiva dispersada entre as gramináceas; iii) florestas que são parcialmente inundadas; e iv) florestas que não sofrem influência das inundações (RADAMBRASIL, 1976; Martinez et al., 2003; Amorim, 2006; Pérez, 2008). 
De acordo com o Projeto "TerraClass"1, cujo objetivo é qualificar o desflorestamento da Amazônia legal, a área de estudo pode ser divida em mais de dez compartimentos, sendo os principais: zona de agropecuária, zona de queimadas, zona desmatada, floresta nativa, vegetação secundária, ocupação urbana, área de mineração, pastagem degradada, pastagem limpa e zona de não floresta. De acordo com essa classificação, vemos que a zona de terra firme/ de inundação inexistente é formada em sua maioria por vegetação secundária, que no caso trata-se de vegetação de floresta que foi desmatada e esta em processo de recuperação; e a zona de inundação/várzea é composta em sua quase totalidade por 'não-floresta' que é uma vegetação composta por gramíneas e árvores de baixo porte (Figura 11).

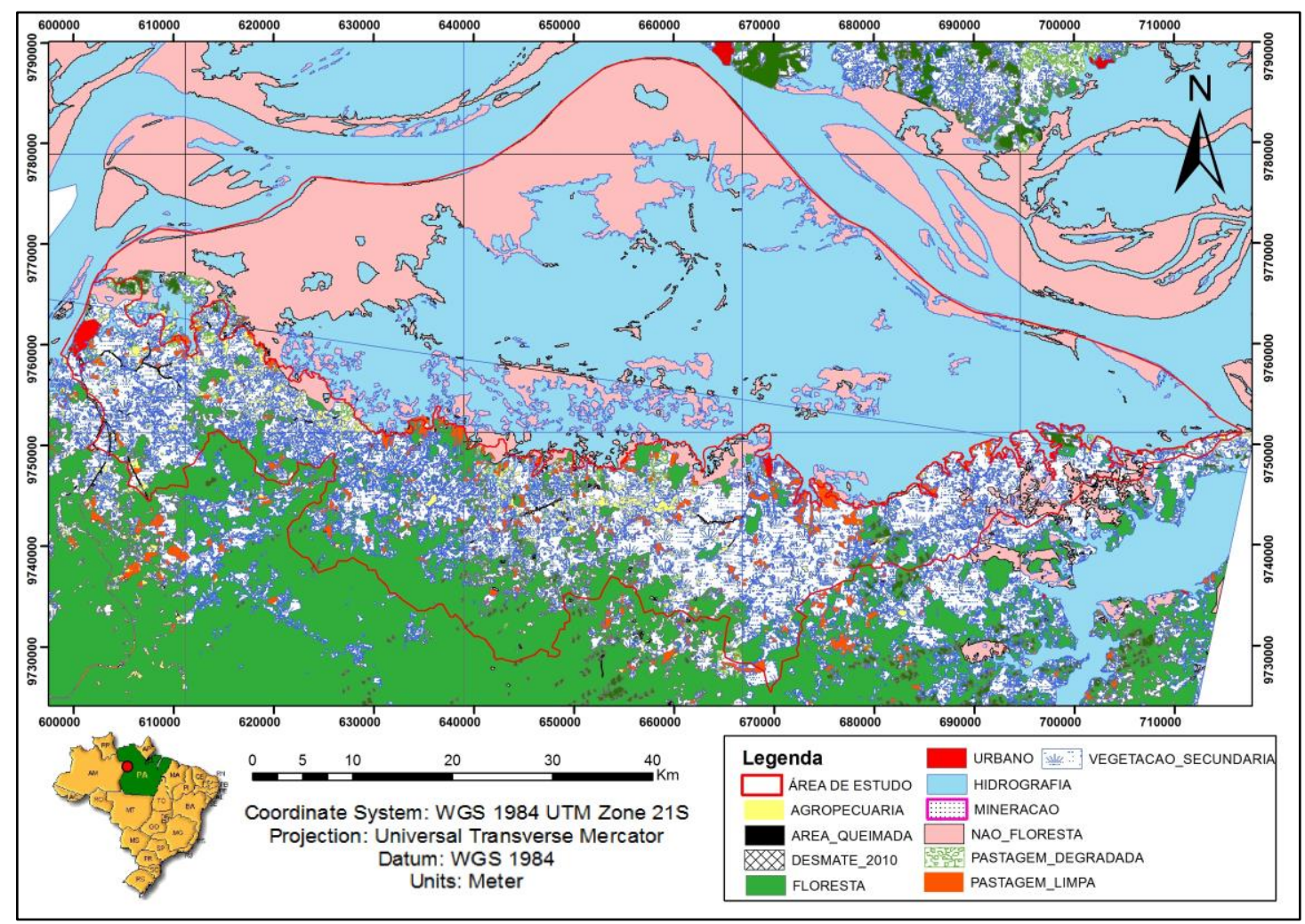

Figura 11 - Distribuição vegetal da área de estudo segundo TerraClass 2010 (Fonte INPE - Instituto Nacional de Pesquisas Espaciais - compilação das cartas: TC_2010_22862 e TC_2010_22861).

\section{5 - Distribuição espacial dos lagos da várzea}

A várzea da região possui mais de trinta lagos interconectados, uma área superficial de aproximademente $3.660 \mathrm{~km}^{2}$ (tamanho estimado da zona de várzea) e está ligada ao rio Amazonas através de um sistema de canais (igarapés) (Figura 12) (Maurice-Bourgoin et al., 2007). É margeada nas porções leste, norte e oeste pelo rio Amazonas. O sistema na margem sul

\footnotetext{
${ }^{1}$ associado ao Instituto Nacional de Pesquisas Espaciais - Centro Regional da Amazônia (INPE/CRA), a Empresa Brasileira de Pesquisa Agropecuária - Embrapa Amazônia Oriental (CPATU), ambas localizadas em Belém - PA, além da Embrapa Informática Agropecuária (CNPTIA), situada em Campinas - SP
} 
é delimitado por terra firme e é onde se localiza a maior parte das comunidades; na porção norte há uma série de ilhas, restingas e terras baixas que separam a várzea do rio Amazonas.

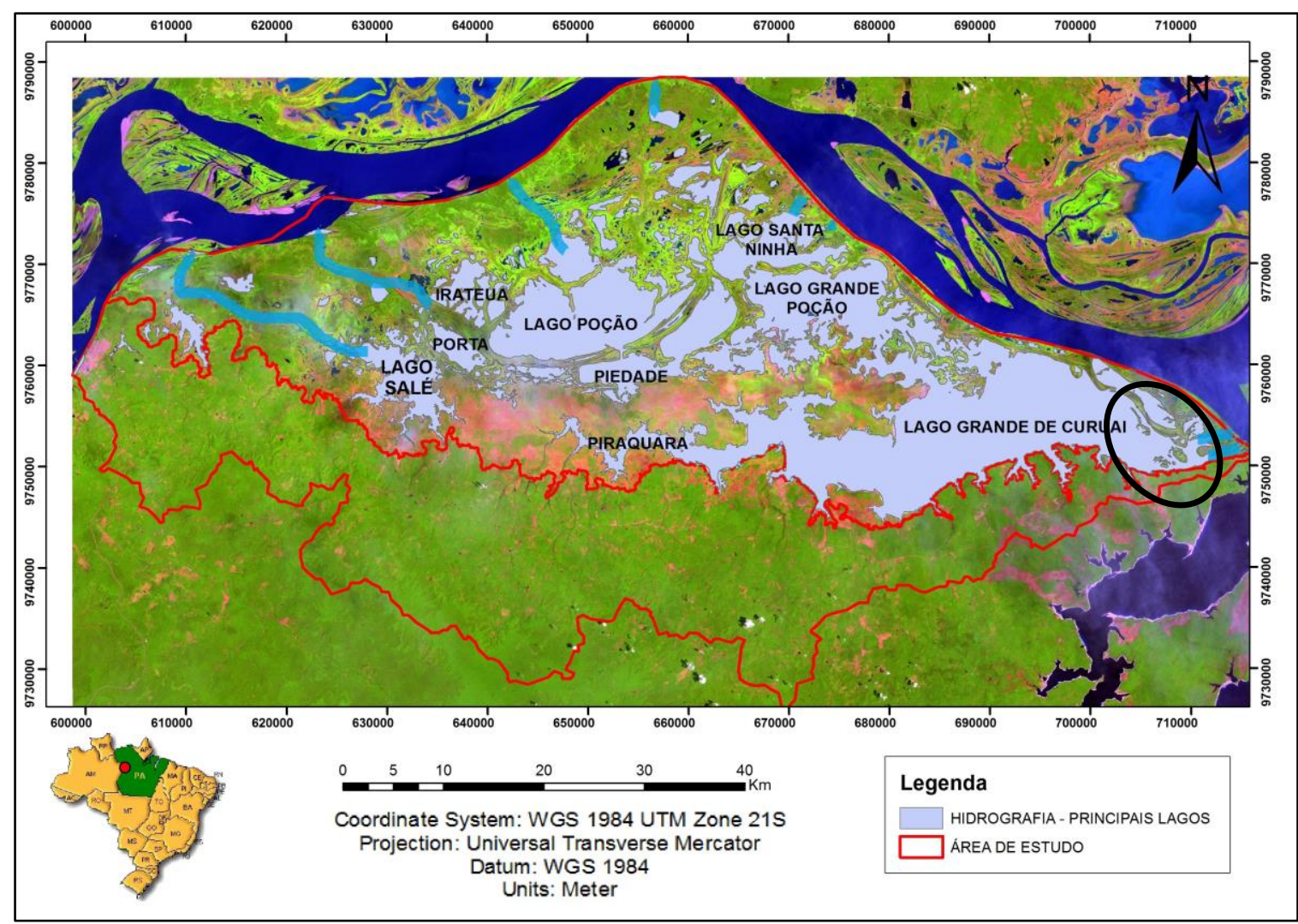

Figura 12 - Principais lagos da área de estudo. Destacada pela elipse preta, observa-se a chamada "boca do lago Grande de Curuai" e em azul mais claro estão representados os traçados dos principais igarapés da área (A base de dados hidrográfica pertencente ao IBGE - com modificações. Imagem representativa da várzea no período da seca de outubro de 2011 - fonte: INPE).

A várzea do lago Grande de Curuai é composta por um complexo sistema de lagos de águas brancas e de águas pretas, alguns diretamente conectados ao rio Amazonas, localizado ao norte da área, e outros fortemente influenciados pela bacia de drenagem de terra firme - sul da área. A várzea está permanentemente conectada ao rio Amazonas por dois canais, Foz Norte e Foz Sul, localizados a Leste na chamada "boca do lago Grande de Curuai” (Pérez, 2008).

O lago Grande de Curuai, com aproximadamente $50 \mathrm{~km}$ de comprimento, é o maior dos lagos que compõem a várzea, razão pela qual recebe este nome embora seja formado por diversos lagos de menor tamanho. Os canais que fazem as ligações do lago com o rio Amazonas possuem aproximadamente 100 metros de largura, três quilômetros de comprimento e seis e doze metros de profundidade nos períodos de seca e cheia, respectivamente (Salcedo, 2011).

O lago Grande apresenta a maior área inundada da várzea, incluindo a área de vegetação inundada, a qual é composta na maior parte por pastagens $\left(274 \mathrm{~km}^{2}\right)$ (Pérez, 2008). Por ser considerada uma área representativa da planície de inundação do médio Amazonas - com lagos e igarapés de diferentes características geoquímicas; lagos de águas brancas - como o lago Grande, 
o lago do Poção, o lago Santa Ana e do lago Salé - e lagos de águas pretas - como o Curumucuri e Açaí), a várzea do lago Grande de Curuai vem sendo objeto de várias pesquisas em hidrogeodinâmica nos últimos 10 anos (Pérez, 2008; HyBAm, 2010).

\section{6 - Ciclo hidrológico}

De acordo com a evolução do nível das águas nos diferentes períodos do ciclo hidrológico, estes sistemas (rio, lagos, igarapés e água subterrânea) influenciam ou são influenciados pelos processos biogeoquímicos que ocorrem nas águas da várzea local (Bonnet et al., 2008; Perez, 2008; Salcedo, 2011). A área inundada pela variação de fluxo da água do lago pode variar de $700 \mathrm{~km}^{2}$, no período seco, a $2.300 \mathrm{~km}^{2}$ no momento do pico de inundação (Martinez et al., 2003).

Quando o nível da água do rio aumenta, vários canais se conectam progressivamente em diferentes partes da planície de inundação do rio principal. O nível máximo de água na várzea ocorre entre maio e junho e o mínimo, entre novembro e dezembro. A profundidade média pode variar de 0,5 metros em baixas águas a 10 metros de coluna d’água em período de cheia (Barbosa, 2005; Maurice-Bourgoin et al., 2005).

As águas do rio Amazonas entram, principalmente, pelos canais que conectam a várzea e o rio Amazonas. Em período de cheia, esses canais alimentam principalmente os lagos Grande, Salé, Poção e Santa Ninha (Figura 12). O fluxo de água entra e cruza a várzea de oeste para leste com uma saída principal pela Boca da várzea na Foz Norte e Foz Sul localizadas na extremidade sudeste do lago Grande (Amorim, 2006).

Com base em dados levantados in situ e por satélite, adquiridos entre 1997 e 2003, foram calculadas pela primeira vez as trocas de água entre a planície de inundação e o rio Amazonas (Bonnet et al., 2008). O rio Amazonas domina as entradas de água para a área durante praticamente todo o ano, o que representa cerca de 70 a $90 \%$ das entradas totais anuais; a precipitação direta (chuvas) e o escoamento superficial são responsáveis por cerca de até $9 \%$ e $10 \%$, respectivamente, enquanto que a infiltração do sistema de águas subterrâneas representa menos de 5\%. O tempo de permanência dessas águas no lago é de cerca de três meses. Esse estudo também revelou que a planície de inundação faz contribuições de água para o rio amazonas. 


\section{4 - Materiais e Métodos}

\section{1 - Características Gerais}

Considerando a grande superfície da área de estudo, o deslocamento pela área era feito em carros, motos e/ou barcos alugados, sempre em companhia de vários pesquisadores integrantes do projeto Clim-FABIAM, de forma que cada pesquisador pudesse aproveitar ao máximo os meios de locomoção e os locais comuns (de possível acesso) para realizar suas pesquisas científicas.

Todas as vias de acesso na parte de terra firme são estradas de chão batido, inclusive a rodovia estadual que corta a região: PA-257. Por se tratar de um local isolado e sujeito a impactos sócio-climáticos (ausência de gasolina nos municípios, árvores caídas, estragos causados as estradas pela chuva, o nível da água impossibilita o trânsito de veículos em certas vias, entre outros) houve dias em que não foi possível realizar trabalho de campo devido a inexistência de transporte para locomoção.

Durante o período dessa dissertação de mestrado foram realizadas três campanhas de coleta de dados em campo: a primeira, realizada entre os dias 25 de maio e 6 de junho de 2014, durante a época de cheia da bacia, teve suas atividades concentradas na caracterização da zona de terra firme. A segunda, realizada entre os dias 24 de novembro e 3 de dezembro de 2014, durante a época de seca da Bacia, teve suas atividades concentradas na caracterização da zona de várzea; e a terceira, entre 4 de maio e 13 de maio de 2015, realizada durante o período de cheia, teve novamente suas atividades concentradas na zona de terra firme. 
Foram descritos/coletados mais de 100 pontos ao longo da área de estudo, incluindo vilas, descrições pedológicas (coleta de amostras) e pontos de controle (Figura 13, Anexo 1)

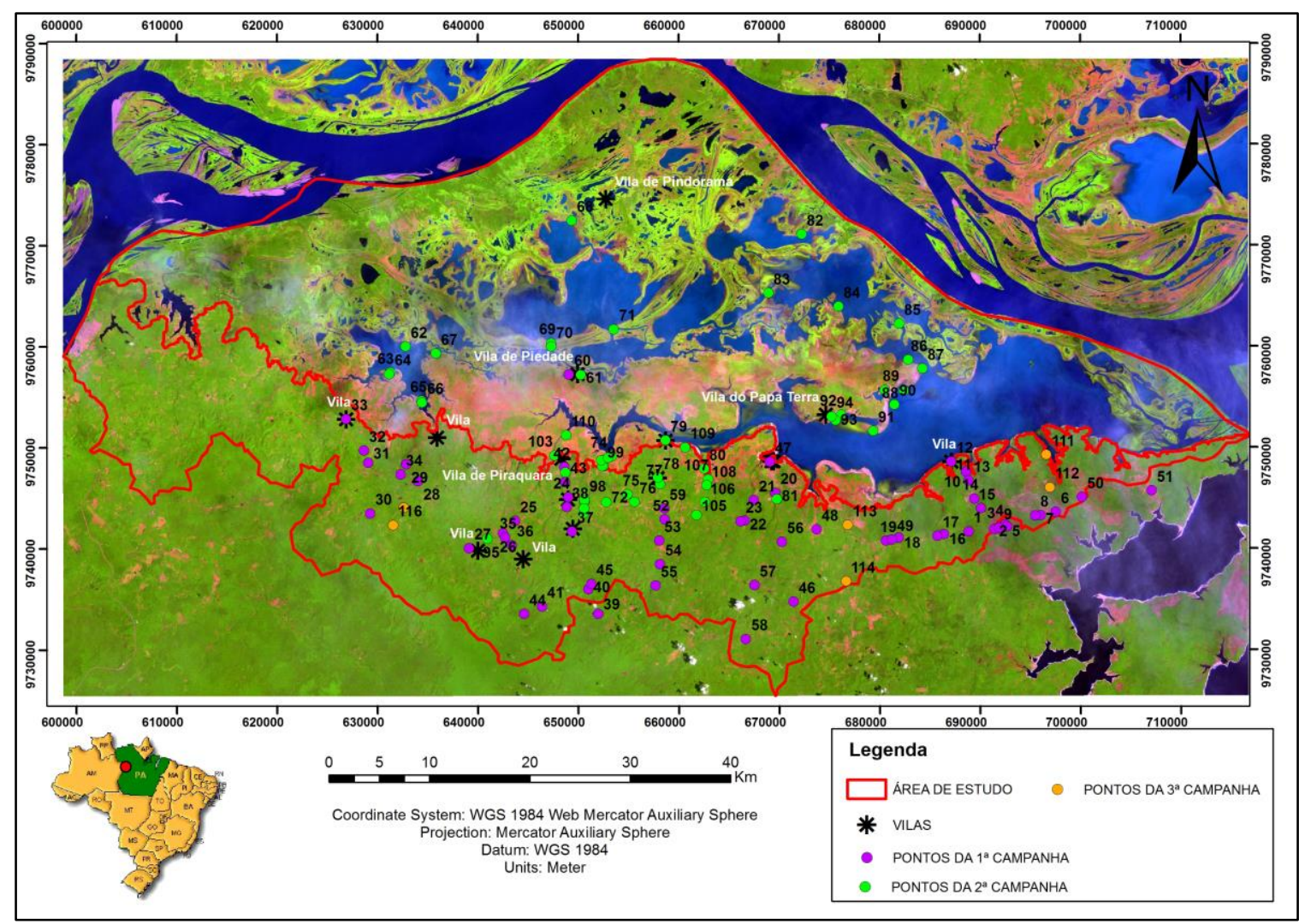

Figura 13 - Pontos estudados durante as missões do projeto Clim-FABIAM para coleta de informações. (Fonte: INPE, imagem referente a seca de outubro de 2011).

\section{3 - Caracterização Física dos Solos}

Para a identificação, caracterização e classificação dos solos observados em campo foram utilizados os critérios e a metodologia descrtitos no "Manual Técnico de Pedologia do IBGE e no Sistema Brasileiro de Classificação de Solos - SiBCS. Com base nisso, foram descritos em campo os critérios apresentados na Tabela 1.

Utilizou-se também lupa de aumento de 20 vezes, facão, trado, canos de PVC, anéis concêntricos de ferro, trena, canivete, câmera fotográfica, bússola geológica tipo Clar DQL-2 ${ }^{\mathrm{a}}$, Carta de Munsell e um GPS Portátil Garmin (GPSMAP 64 - calibrado em UTM-WGS84-Zona 21S). 
Tabela 1 - Tabela utilizada em campo para avaliação dos tipos de solo.

\begin{tabular}{|c|c|c|c|}
\hline PONTO & COORDENADAS & HORIZONTE & ESPESSURA \\
\hline & & \multicolumn{2}{|c|}{ ESTRUTURA } \\
\hline \multicolumn{4}{|c|}{ CONSISTÊNCIA } \\
\hline TRANSIÇÃO & TEXTURA & MOLHADA & PLASTICIDADE \\
\hline & & & SOLO \\
\hline SECA & ÚMIDA & MINERALOGIA & \\
\hline \multicolumn{5}{|c|}{} \\
\hline \multicolumn{5}{|c|}{ COR } & & \\
\hline
\end{tabular}

A Figura 14 apresenta os principais princípios pedológicos, classificações e outras ferramentas utilizadas pra descrever e caracterizar os perfis de solos: i) a figura 'a' mostra um perfil de solo, com seus diferentes horizontes; ii) a figura ' $b$ ' dá exemplos dos tipos de transição entre os horizontes do solo; iii) a figura 'c' retrata o triângulo textural (classes texturais da fração terra fina) utilizado na classificação da textura do solo; iv) a figura 'd'exemplifica os tipos de estruturas observadas no solo; v) a figura 'e' é um modelo da carta de Munsell utilizada em campo na classificação das cores do solo e, por fim, vi), a figura ' $\mathrm{f}$ ' retrata a tabela de classificação dos solos utilizada pela EMBRAPA. 


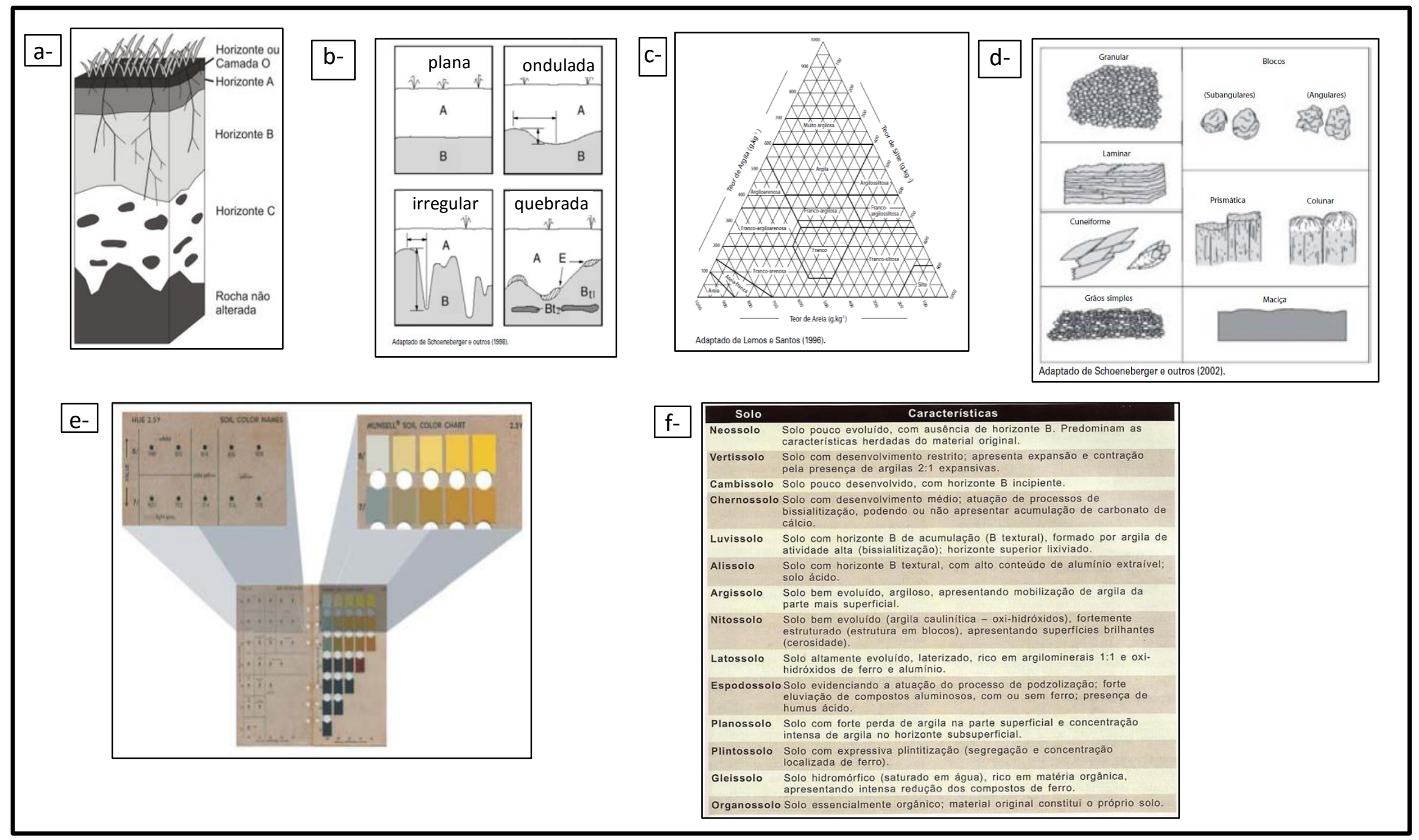

Figura 14 - Prancha exemplificativa dos parametrôs utilizados em campo para caracterização e classificação dos solos. 


\subsection{Propriedades Hidráulicas do solo}

O processo de infiltração é a transferência de água da superfície para o interior do solo. É um fenômeno que depende da água disponível para infiltrar, da natureza do solo (tipo de solo, textura), do estado da superfície (grau de compactação e impermeabilidade), da quantidade de água e ar, inicialmente presentes no seu interior, da inclinação do terreno, da cobertura vegetal (raízes, folhas, frutos e da matéria orgânica no geral) e do tipo de chuva. À medida que a água infiltra pela superfície, as camadas superiores do solo vão se umedecendo de cima para baixo, alterando gradativamente o perfil de umidade (Brandão et al., 2006).

Em 1856, o engenheiro francês Henry Darcy formulou a primeira teoria referente ao fluxo das águas subterrâneas através de ensaios em colunas de areia saturada. A lei de Darcy é utilizada ainda hoje como princípio básico do escoamento das águas subterrâneas (Carneiro et al.,1997; Fiori, et al., 2010).

Os valores de condutividade hidráulica vertical dos solos são importantes para estudos do ciclo hidrológico, de contaminação das águas subterrâneas, pesquisas em projetos de irrigação, análise de perda de solos e avaliação geotécnica.

Segundo Freeze \& Cherry (1979) e Fetter (1994), valores típicos de condutividade hidráulica podem ser classificados como: $>10^{-3} \mathrm{~m} / \mathrm{s}$ muito alta, $10^{-3}$ a $10^{-5} \mathrm{~m} / \mathrm{s}$ alta, $10^{-6} \mathrm{~m} / \mathrm{s}$ moderada, $10^{-7}$ a $10^{-8} \mathrm{~m} / \mathrm{s}$ baixa e $<10^{-8} \mathrm{~m} / \mathrm{s}$ muito baixa. De acordo com a classificação apresentada, o valor de $\mathrm{Kv}$ com ordem de grandeza de $10^{-6} \mathrm{~m} / \mathrm{s}$ pode ser considerado como limite entre valores altos e valores baixos (Fiori, et al., 2010).

Para a determinação das propriedades hidráulicas do solo foram usados dois métodos, considerados os mais adequados e acessíveis as condições de estudo: método do infiltrômetro de anéis concêntricos e o método do "Open end Hole" que permitem determinar a condutividade hidráulica vertical in situ.

\subsubsection{Anéis Concêntricos}

Tal método consiste em cravar dois cilindros concêntricos na terra (Figura 15) - anel externo e anel interno - de forma a evitar uma dispersão superficial da água inserida tanto para fora dos cilindros quanto de um cilindro para o outro. Após cravar-se os anéis deve-se nivelá-los e adicionar água no anel externo repetidas vezes de forma a atingir o nível de saturação do solo, dessa forma a condutividade hidráulica $(\mathrm{K})$ medida no anel central refere-se apenas a componente vertical Kv.

A condutividade vertical em superfície é medida através da aplicação da equação: 


$$
K_{V}=\mu \frac{I}{\Delta t} \ln \left(\frac{h_{0}}{h}\right)
$$

onde; $K_{V}$ : condutividade hidráulica vertical; $I$ : profundidade na qual a peça está cravada no solo (mm); $\Delta t$ : tempo de ensaio (min); $\mu$ : constante $1 / 60000$ (conversão de $\mathrm{mm} / \mathrm{min}$ para $\mathrm{m} / \mathrm{s}$ ); $h_{0}$ : altura da coluna inicial (mm); $h$ : altura da coluna final (mm). Para o cáuculo de $h_{0}$ e $h$, utilizamse as seguintes equações: $h_{0}=H_{c}-I-M_{i}$ e $h=H_{c}-I-M_{f}$, onde $H_{c}$ : altura do infiltrômetro de anéis concêntricos; $M_{i}$ : medida do topo do infiltrômetro até o nível da água do compartimento interno no instante inicial $t_{0} ; M_{f}$ : medida do topo do infiltrômetro até o nível da água do compartimento interno no instante final $t$.

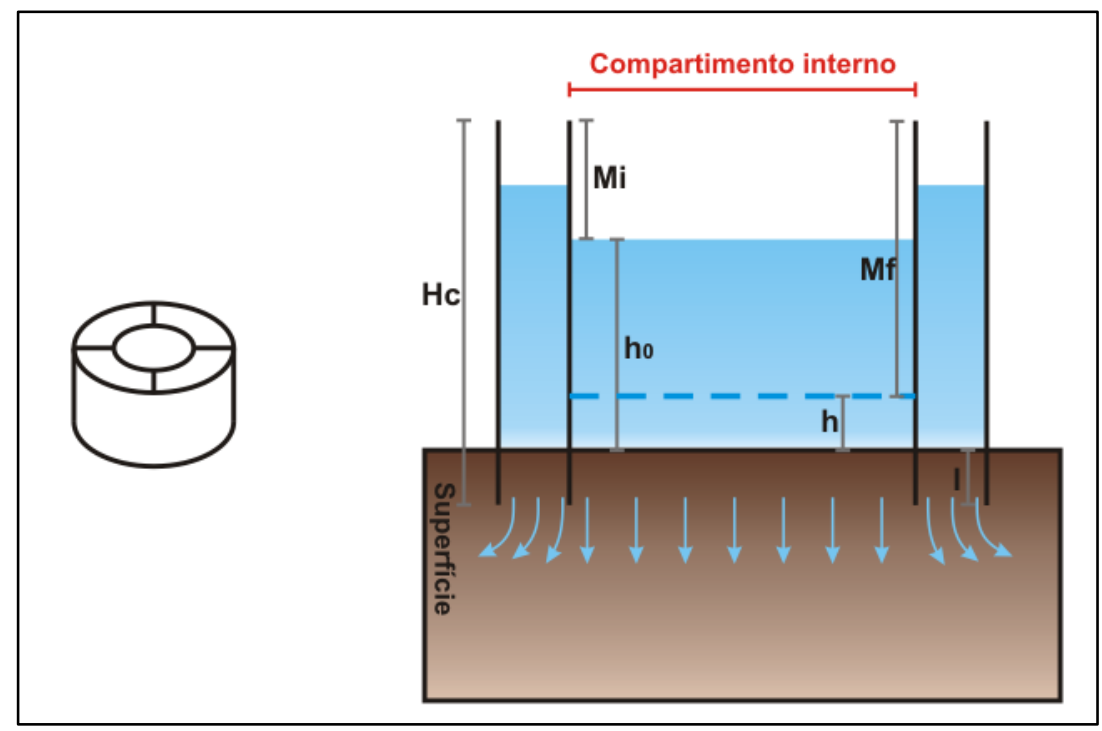

Figura 15 - Modelo esquemático do funcionamento dos anéis concêntricos.

\subsection{2. "Open end Hole"}

Este método está relacionado com a capacidade de infiltração do solo em profundidade, denominado open end hole. Consiste em furos de diferentes profundidades onde um cano de PVC é inserido e preenchido com água (Figura 16).

Neste método são realizados 'n' furos no solo, com distância média de $1 \mathrm{~m}$ entre eles, e variações de aproximadamente $50 \mathrm{~cm}$ na profundidade - utiliza-se escavadeiras e trados manuais para a realização das perfurações. Nestes furos são inseridos tubos de PVC, para que não haja dispersão lateral da água que vai ser inserida.

Após a inserção dos tubos, adiciona-se água até uma certa altura e mede-se com uma trena a distância entre a superfície da água e o topo do tubo. Após um determinado intervalo de tempo, mede-se novamente a distância da superfície da água até o topo do tubo. Com isso tem-se a altura da coluna d'água inicial e final.

Com esses dados determina-se o Kv, a partir da equação: 


$$
K_{V}=2.303\left(\frac{R}{4 \Delta t}\right) \log h_{0} / h
$$

onde; $K_{V}$ : condutividade hidráulica vertical $(\mathrm{m} / \mathrm{s}) ; \mathrm{R}$ : raio do tubo de revestimento $(\mathrm{m}) ; \Delta t$ : tempo de ensaio $(\mathrm{s}) ; h_{0}$ : altura inicial da coluna d'água $(\mathrm{cm}) ; h$ : altura final da coluna d'água $(\mathrm{cm})$. Para o cálculo de $h_{0}$ e $h$, utilizam-se as seguintes equações: $h_{0}=H-M_{i} \quad$ e $\quad h=H-M_{f}$, onde $H$ : altura do topo do cano até o fundo do buraco; $M_{i}$ : medida do topo do cano até o nível da água no instante inicial $t_{0} ; M_{f}$ : medida do topo do cano até o nível da água no instante final $t$.

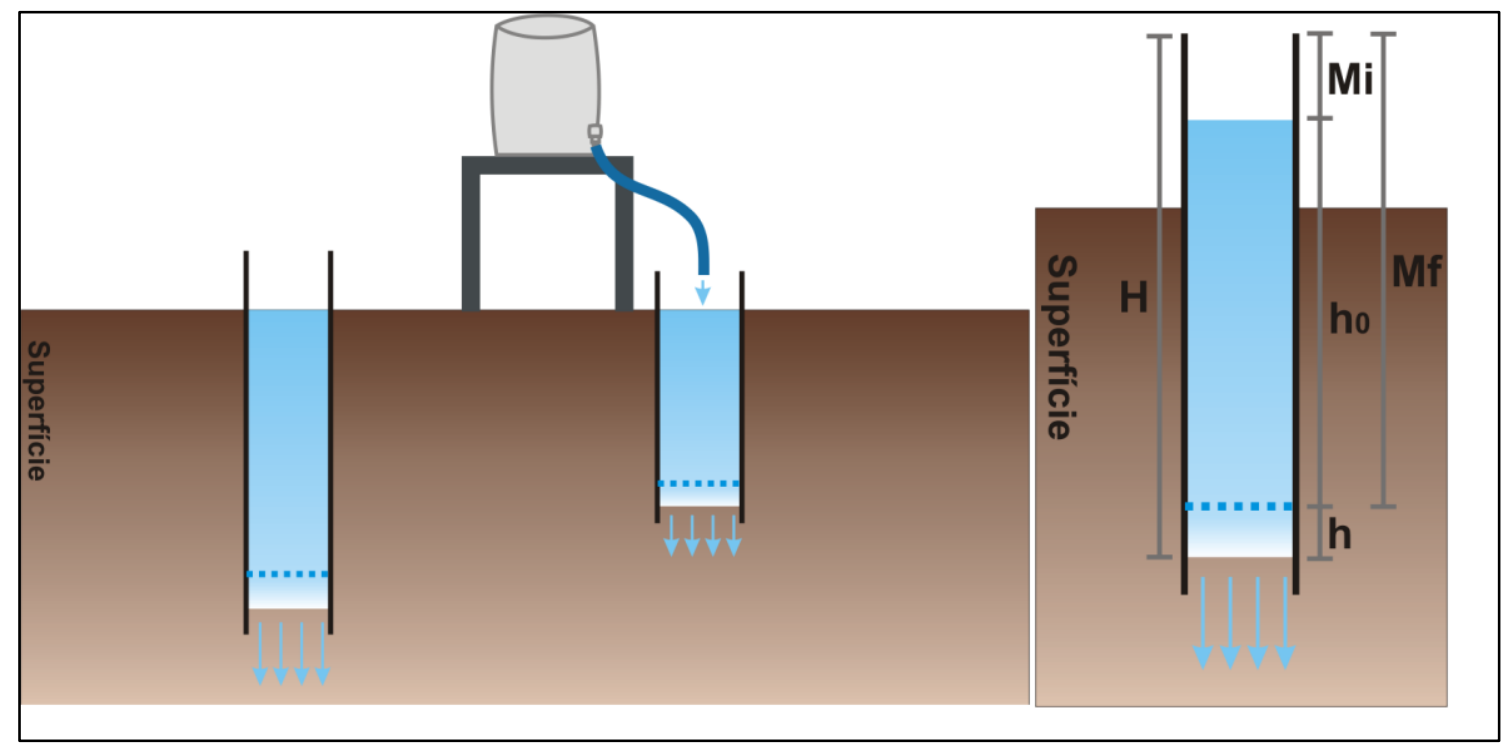

Figura 16 - Modelo esquemático do funcionamento do método "open end hole".

Os procedimentos descritos acima foram realizados de forma bem sucedida em seis pontos durante a primeira campanha de campo (pontos: 37, 38, 42, 43, 44 e 45 - análises realizadas durante o período de cheia da Bacia) e em mais sete pontos durante a segunda campanha de campo (pontos: 95, 98, 100, 104, 107, 109 e 110 - análises realizadas durante o período de seca da Bacia).

\section{5 - Análises laboratoriais}

Os dados levantados em campo foram complementados com análises em laboratório que permitiram obter dados sobre a mineralogia (análises por difratometria de raio-X), granulometria, porcentagem de massa perdida pela exposição ao fogo (perda ao fogo) e a geoquímica das amostras (composição - elementos maiores).

\subsection{1 - Análises de Mineralogia por Difratometria de Raio-X (DRX)}

O estudo da mineralogia das amostras coletadas foi realizado no Laboratório de Difratometria de Raios-X (LDRX), do Instituto de Geociências (IG-UnB). Por meio de análises utilizando-se difratômetro Rigaku, modelo Ultima IV. Foram feitas análises da Terra Fina Seca ao Ar (TFSA), "total”, que indica a composição mineral dos constituintes maiores que a fração 
argila; e da fração argila, individualizada da TFSA por meio de suspensão aquosa, seguida da dispersão mecânica e centrifugação, conforme a o protocolo do Laboratório de DRX. Para a preparação destas análises, é necessário realizar a separação mecânica entre amostra e matéria orgânica.

$\mathrm{Na}$ análise da rocha total, as amostras são desagregadas mecanicamente com martelo e em gral de ágata. O pó resultante é compactado a seco em uma lâmina de vidro que possui uma cavidade retangular, e é levada para análise em um Difratômetro de Raios-X Rigaku Ultima IV, operando com tubo de cobre e filtro de níquel, sob voltagem de $35 \mathrm{kV}$ e $15 \mathrm{~mA}$, à velocidade de varredura de $2^{\circ} / \mathrm{min}$, em um ângulo de leitura de 3 a $80^{\circ}$.

Para a identificação dos argilominerais, adota-se o procedimento de rotina do LDRX que consiste em realizar a dispersão da amostra pulverizada e posterior centrifugação em centrífuga ThermoScientific IEC CL31R Multispeed por sete minutos a $750 \mathrm{rpm}$. O sobrenadante é separado e novamente centrifugado, desta vez por 30 minutos a $3.000 \mathrm{rpm}$. Ao final do processo espalha-se o material do fundo sobre uma lâmina de vidro utilizando-se a técnica do esfregaço, seco ao ar e posteriormente a lâmina é analisada por DRX de 3 a $40^{\circ}$, mantendo-se as demais condições de análise da rocha total. Posteriormente, estas mesmas lâminas passaram por tratamento com etileno-glicol (glicolagem), que consiste em tratar as lâminas por aproximadamente 15 minutos em ambiente selado, seguido por repouso de aproximadamente 12 horas, à vácuo, e posterior análise por DRX. Por último, todas as lâminas são aquecidas à $490^{\circ} \mathrm{C}$, esperando então que a temperatura se normalizasse para realizar a ultima medida. Os tratamentos secundários (glicolagem e aquecimento) são incluídos no processo de identificação com o objetivo de obter maior segurança na identificação dos minerais (Anexo 2) .

A interpretação dos difratogramas é feita com o auxílio do programa JADE 9.4 da MDI, que possui, em seu banco de dados, padrões de difração de centenas de minerais.

\subsubsection{Análises de Granulometria do Solo}

As análises de granulometria das amostras de solo foram realizadas no Laboratório do Centro de Formação de Recursos Humanos em Transportes (Ceftru) da Universidade de Brasília, mais especificamente no Laboratório de Infraestrutura (Infralab), no setor de análises de solo. As análises foram realizadas seguindo metodologia proposta por EMBRAPA (2012), metodologia padrão do Infralab.

A análise granulométrica de um solo é o estudo do tamanho das partículas ou grãos que compõem este solo; faz-se distribuindo as diversas frações de solos conforme seus tamanhos. Esta análise serve para classificar, determinar e orientar as possíveis aplicações do solo na 
agricultura e engenharia civil. A demais, participa ativamente no controle de infiltração de água no solo, influenciando na estrutura e na propriedade dos grãos na retenção de água.

\subsubsection{Análise Geoquímica do Solo}

As análises geoquímicas dos solos foram feitas visando-se a geração de dados específicos sobre a região de estudo, como a composição química dos solos e a quantidade de carbono orgânico total das amostras coletadas.

As análises químicas do solo costumam ser realizadas com fins de classificação pedológica, agronômica e interesse pedogenético. Vários parâmetros podem ser definidos em função dos objetivos (composição total, a quantidade efetiva de cargas negativas/positivas no solo, determinação dos elementos trocáveis, balanço químico). Além disso, elas também servem para indicar se a composição química do solo está de acordo com a mineralogia nele presente e com o protólito (rocha fonte), distinguir os solos entre si, caracterizar a pedogênese e funcionamento pedológico. Um parâmetro muito utilizado no que diz respeito à fertilidade química dos solos é a estimativa da quantidade carbono orgânico total no solo, a qual pode ser determinada por diversos métodos (Hutzinger, 1980; Hutzinger ,1986; Chester, 1990)

Todas as análises foram realizadas no laboratório de geoquímica da Universidade de Brasília (LAGEQ/UnB), e com apoio de Laboratórios Parceiros (Universidade de Toulouse e Montpellier (França)).

\subsubsection{1 - Análise Química dos Solos}

As análises químicas do solo seguiram o padrão descrito pelo Manual de métodos de análise de solo da Embrapa (1997). A digestão das amostras de solos foi realizada seguindo um protocolo de múltiplos passos $\left(\mathrm{H}_{2} \mathrm{O}_{2}, \mathrm{HNO}_{3}, \mathrm{HF}, \mathrm{HCl}\right)$. Os seguintes elementos: $\mathrm{Ca}, \mathrm{Mg}, \mathrm{Na}, \mathrm{K}$, $\mathrm{Si}, \mathrm{Al}, \mathrm{Fe}, \mathrm{Mn}$ e Ti, foram analisados três vezes por ICP-AES (Inductively Coupled Plasma Atomic Emission Spectrometry) a partir das soluções de digestão.

Após as análises químicas foi realizado o cálculo de CIA (“Chemical Indice of Alteration", ou índice de intemperismo) que é uma relação entre os elementos $\mathrm{Al}_{2} \mathrm{O}_{3}$ considerados pouco solúveis (imóveis) e que permanecem constantes e elementos cuja concentração diminui a medida em que o grau de intemperismo e a lixiviação aumentam $(\mathrm{CaO}$, $\left.\mathrm{MgO}, \mathrm{Na}_{2} \mathrm{O}, \mathrm{K}_{2} \mathrm{O}\right)$. Este índice CIA $\left(\mathrm{Al}_{2} \mathrm{O}_{3} / \mathrm{Al}_{2} \mathrm{O}_{3}+\right.$ bases $)$ foi proposto por Nesbitt e Young (1982).

\subsubsection{2 - Análise de Carbono Orgânico por Perda ao Fogo}

A concentração de Carbono Orgânico Total (COT) foi determinada a partir da metodologia de Perda ao Fogo (PF) de De Vos et al. (2005). 
De Vos executou seu trabalho em solos de florestas temperadas da região do norte da Bélgica em solos descritos como espodossolo, entissolo, litossolos, alfissolo e inceptissolo, e concluiu que a concentração de carbono orgânico total por perda ao fogo pode ser calculada pela seguinte fórmula:

$$
\mathrm{COT}=0,573 *(\mathrm{PF})
$$

O procedimento realizado na $\mathrm{UnB}$ foi feito de forma adaptada: 2,1 $\mathrm{g}$ da amostra pulverizada foi levada à estufa a $70^{\circ} \mathrm{C}$ por 12 horas. Cadinhos de cerâmica foram colocados em mufla, por uma hora a $1.000^{\circ} \mathrm{C}$, pesados, e o valor obtido anotado na planilha "Análise de Perda ao Fogo". As amostras então foram levadas à mufla, a $1.000^{\circ} \mathrm{C}$, por duas horas, sendo necessário abri-la periodicamente para que houvesse escape dos elementos voláteis que impediriam a calcinação completa. Os cadinhos foram colocados no dessecador até atingirem a temperatura ambiente, pesados e o valor do peso total (peso do cadinho padrão + peso da amostra após aquecimento a $1.000^{\circ} \mathrm{C}$ ) anotado na planilha. As análises de perda ao fogo foram repetidas em um período de uma hora após a primeira análise a fim de verificar se houve mudança significativa de massa (5\% como tolerância) e por fim tiveram seus valores de COT calculados seguindo De Vos et al. (2005).

\subsection{Análise Isotópica de Água}

As várzeas são sistemas de reciclagem de água e matéria que ocorrem ao longo da Bacia Amazônica e em diversas partes do mundo. As águas observadas na várzea do Lago Grande de Curuai são o resultado das misturas da água da chuva, com a água do rio Amazonas, com as águas que percorrem a terra firme, correm nos lençóis freáticos e se conectam ao lago de Curuai por meio dos igarapés.

A contribuição desses compartimentos (rio amazonas, igarapés, lençol freático e água da chuva) ao longo do ciclo hidrológico é ainda mal conhecida. Assim, esse trabalho optou estudar o ciclo da água na escala da várzea de Curuai com uso dos isótopos da água a fim de aprender um pouco mais sobre esses compartimentos.

\subsection{1 - Conceito:}

As diferentes espécies isotópicas da molécula de água $\left(\mathrm{H}_{2} \mathrm{O}:{ }^{1} \mathrm{H},{ }^{2} \mathrm{H},{ }^{3} \mathrm{He}{ }^{16} \mathrm{O},{ }^{17} \mathrm{O}\right.$ e $\left.{ }^{18} \mathrm{O}\right)$. tem massas e simetrias diferentes. A proporção relativa destas diferentes moléculas é denominada de composição isotópica e é quantificada pela notação $\delta$ (d) segue exemplo por $\delta^{18} \mathrm{O}$ :

$$
\delta 180 \text { amostra }=\left(\frac{\left(\frac{180}{160}\right) \text { amostra }}{\left(\frac{180}{160}\right) \text { VSMOW }}-1\right) * 1000
$$


Durante a maior parte das alterações de fase da água (evaporação, precipitação), os diferentes isótopos são redistribuídos entre os estados físicos da água (líquido, gelo, vapor) e este processo é chamado de fracionamento isotópico. As razões físicas para o fracionamento de isótopos ultrapassam o escopo desta dissertação, mas em resumo, o fracionamento isotópico tem duas causas: termodinâmica e cinética.

Por um lado, as diferenças de massa induzem um fracionamento dito termodinâmico onde, em equilíbrio, as moléculas as mais pesadas $\left({ }^{18} \mathrm{O}\right)$ ficam concentradas na fase mais condensada (líquido ou gelo). Por exemplo, durante condensação de vapor a $20^{\circ} \mathrm{C}$, o condensado tem um $\delta^{18} \mathrm{O} 9.5 \%$ mais alto do que o vapor. Este fracionamento é dependente da temperatura. Por exemplo, a $+10^{\circ} \mathrm{C} \mathrm{e}-10^{\circ} \mathrm{C}$, o condensado é respectivamente $10.5 \%$ e $16.5 \%$ mais rico do que a vapor.

Por outro lado, a diferença de difusividade molecular entre estas espécies isotópicas (em relação à massa e à simetria das moléculas) induz a uma cinética de fracionamento. As moléculas mais pesadas tem uma difusividade inferior. Assim, por evaporação, a composição do fluxo de evaporação é mais pobre em um caso de reação realizada "fora do equilíbrio" que a mesma reação realizada em equilíbrio termodinâmico. O fracionamento cinético depende especialmente da umidade relativa e da difusividade turbulenta e molecular dos isótopos no ar.

Mais concretamente vários "efeitos" e contextos alteram diretamente a composição isotópica da água:

- O efeito dito da temperatura: Quanto maior é a temperatura do ar durante um evento de chuva, mais leve será a assinatura isotópica das precipitações (Figura 17a). Por consequência, o $\delta^{18} \mathrm{O}$ das precipitações mostra principalmente uma distribuição zonal, com uma composição cada vez mais pobre quando a latitude aumenta. Esta feição conduz a um efeito dito de latitude e altitude (Figura 17e) e de sazonalidade (Figura 17c) - os valores das concentrações isotópicas diminuem com as mudanças de estação (verão - inverno) (Friedman et al, 1964; Moser e Stichler, 1970; Frischkorn et al., 1990).

- O efeito de interiorização ou continentalidade (Figura 17e) (Santiago, 1984):

Os eventos de condensação sucessivos conduzem a uma perda gradual de massa de ar durante o seu transporte para os polos; as precipitações são cada vez mais pobres (empobrecidas em isótopos pesados e mais ricas em isótopos leves) quando se deslocam em direção aos polos Norte e Sul. De forma geral, à medida que há transporte de massas de ar pelo continente, uma parte do vapor precipita (vapor de água pesada tende a se condensar mais facilmente), esgotando-se em isótopos pesado de forma que a massa de vapor passa por um efeito conhecido como "destilação de Rayleigh". 
O efeito da continentalidade é menos pronunciado na Amazônia, onde a reciclagem das precipitações por re-evaporação é mais forte (Rozanski et al., 1993).

- O efeito de massa ou "quantidade eficaz". Finalmente, há um terceiro efeito que também controla a composição isotópica e esta fortemente ligado ao efeito de interiorização. Devido ao fenômeno de destilação de Rayleigh, as chuvas mais intensas tem valores de $\delta^{18} \mathrm{O}$ menores, ou seja, são mais leves ou pobres em isótopos pesados (Figura 17b). Este efeito é desempenhado principalmente nos trópicos (Dansgaard, 1964).

A conclusão que podemos tirar desse efeitos de forma simplificada é que a evaporação e a condensação são os dois processos que mais influenciam na razão dos isótopos da águas. Assim, em hidrogeologia, isótopos da molécula de água podem ser utilizados como traçadores. As mudanças da assinatura isotópica durante o seu ciclo pode permitir rastrear as fontes da água e as misturas. 


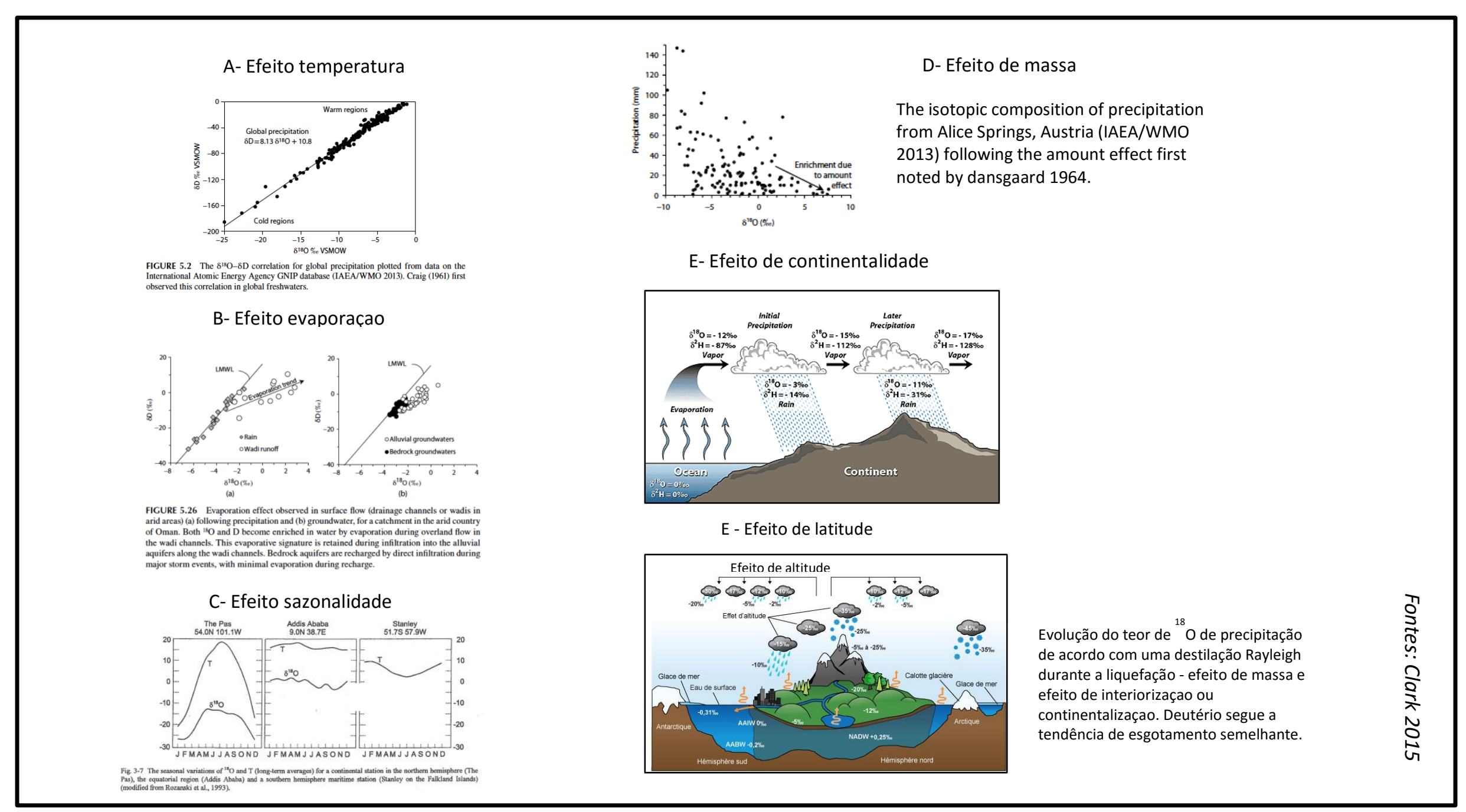

Figura 17 - Efeitos/ causas de fracionamento isotópico da água. 
Amostras de água foram coletadas em diferentes compartimentos da área de estudo (no rio amazonas, na várzea - lagos, igarapés, poços artesianos, bem como a água da chuva), filtradas em filtro de $0,2 \mu \mathrm{m}$ e armazenadas em garrafas plásticas de um litro.

No laboratório de geocronologia da Universidade de Brasília (UnB), as assinaturas de $\partial^{2} \mathrm{H}$

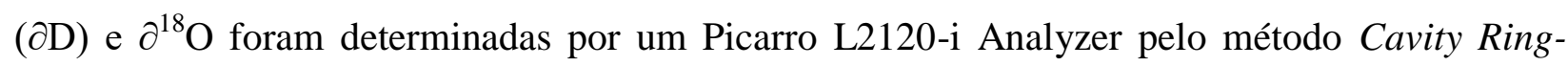
Down Spectroscopy (CRDS). As composições de isótopos de $\partial \mathrm{D}$ e $\partial^{18} \mathrm{O}$ de todas as amostras são reportados em notação padrão delta, relativa ao material de referência SMOW (Standard Mean Ocean Water), e expressa em \%o, com erro associado: $\partial \mathrm{D}=1 \%$, $\partial^{18} \mathrm{O}=0,2 \%$. A razão $\mathrm{D} / \mathrm{H}(\delta \mathrm{D})$ no padrão Viena Standard Mean Ocean Water (VSMOW) é de 155,76*10 ${ }^{-6}$, enquanto que a razão entre $\left(\delta^{18} \mathrm{O}\right){ }^{18} \mathrm{O} /{ }^{16} \mathrm{O}$ é de $2005,2 * 10^{-6}$, ambas as razões são deslocadas a zero para servirem como padrões de comparação.

\section{7 - Softwares utilizados}

Durante todas as etapas dessa dissertação tiveram alguns programas de computador que foram indispensáveis. Além de todo o pacote Office, foram utilizados: para a elaboração de mapas o Arcgis 10.1, para o tratamento de imagens de satélite o ENVI 4.7, para a avaliação física da área de mapeamento o Google Earth, para o tratamento dos dados de GPS o Global Mapper 10.1 e para a elaboração de figuras o Corel Draw X6. 


\section{5 - Resultados e Discussão:}

\section{1 - Distribuição espacial dos pontos coletados durante as campanhas de campo}

Durante as duas primeiras campanhas de campo realizadas pelo projeto foi possível a observação de mais de 100 diferentes pontos ao longo da área (Figura 18), onde foram descritos os tipos de solo (coletado algumas amostras), o porte da vegetação e o relevo associado aos solos e realizada a coleta de amostras de água em igarapés e poços artesianos.

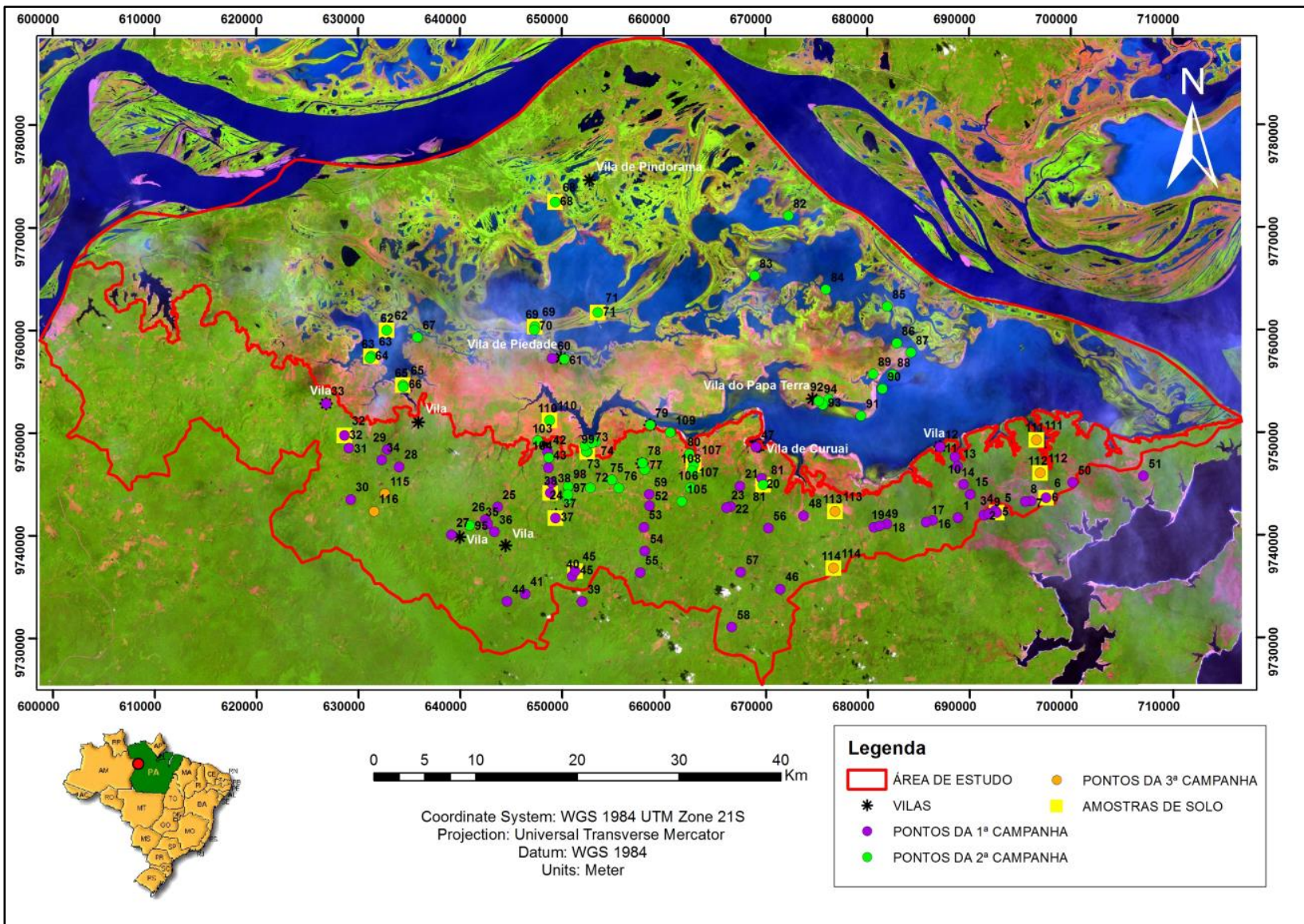

Figura 18 - Distribuição espacial dos pontos visitados durante as missões do projeto Clim-FABIAM para coleta de informações pedológicas. (Fonte: INPE, imagem referente a seca de outubro de 2011).

As análises de granulometria, mineralogia e composição química dos solos foram conduzidas sobre uma seleção de amostras representativas dos solos encontrados durante as campanhas de amostragem (Figura 18 e Tabela 2). Uma boa repartição dos pontos assim como um transecto (topossequência) da geomorfologia da bacia foram considerados na seleção. 
Tabela 2 - Descrição simplificada do local de coleta das amostras de solo.

\begin{tabular}{|c|c|c|c|}
\hline PONTO & COORD X & COORD Y & LOCAL DE COLETA \\
\hline 5 & 692680 & 9742157 & $\begin{array}{l}\text { VEGETAÇÃO: CAMPO SUJO. A ÁREA COSTUMAVA SER UM AMBIENTE DE } \\
\text { FLORESTA ATÉ SER DESMATADA PARA A IMPLEMENTAÇÃO DE UM ROÇADO DE } \\
\text { MANDIOCA. }\end{array}$ \\
\hline 6 & 697538 & 9743580 & VEGETAÇÃO RASTEIRA (CAMPO SUJO), "PASTO NATURAL" \\
\hline 32 & 628621 & 9749717 & $\begin{array}{l}\text { AMBIENTE DE FLORESTA EM RECUPERAÇÃO (VEGETAÇÃO SECUNDÁRIA). RELEVO } \\
\text { CARACTERÍSTICO: ONDULADO, ÁREA DE SERRA }\end{array}$ \\
\hline 37 & 649355 & 9741678 & $\begin{array}{l}\text { O LOCAL COSTUMA SER UMA FLORESTA ATÉ QUE FOI DESMATADO PARA } \\
\text { IMPLEMENTAÇÃO DE PASTO PARA PECUÁRIA }\end{array}$ \\
\hline 38 & 648836 & 9744108 & $\begin{array}{c}\text { ÁREA DE FLORESTA COM INTERFERÊNCIA HUMANA - IMPLANTAÇÃO DE } \\
\text { AGROFLORESTA (UTILIZAÇÃO DA ÁREA PARA O CULTIVO DE FRUTÍFERAS COMO } \\
\text { AÇAI E CUPUAÇU). }\end{array}$ \\
\hline 45 & 651256 & 9736489 & FLORESTA NATIVA \\
\hline 62 & 632787 & 9760002 & ZONA DE VÁRZEA, VEGETAÇÃO RASTEIRA \\
\hline 63 & 631275 & 9757443 & ZONA DE VÁRZEA, VEGETAÇÃO RASTEIRA \\
\hline 65 & 634397 & 9754638 & ZONA DE VÁRZEA, VEGETAÇÃO RASTEIRA \\
\hline 68 & 649333 & 9772469 & ZONA DE VÁRZEA, VEGETAÇÃO RASTEIRA \\
\hline 69 & 647314 & 9760328 & ZONA DE VÁRZEA, VEGETAÇÃO RASTEIRA \\
\hline 71 & 653531 & 9761709 & ZONA DE VÁRZEA, VEGETAÇÃO RASTEIRA \\
\hline 73 & 652486 & 9748133 & ZONA DE TRANSIÇÃO ENTRE A ÁREA DE TERRA FIRME E A ZONA DE VÁRZEA \\
\hline 81 & 669761 & 9744883 & VEGETAÇÃO SECUNDÁRIA, ÁREA DE FLORESTA EM RECUPERAÇÃO \\
\hline 107 & 662908 & 9746842 & ZONA DE TRANSIÇÃO ENTRE A ÁREA DE TERRA FIRME E A ZONA DE VÁRZEA \\
\hline 110 & 648794 & 9751211 & ZONA DE VÁRZEA, VEGETAÇÃO RASTEIRA \\
\hline 111 & 696599 & 9749245 & ZONA DE TRANSIÇÃO ENTRE A ÁREA DE TERRA FIRME E A ZONA DE VÁRZEA \\
\hline 112 & 696952 & 9746014 & VEGETAÇÃO SECUNDÁRIA, ÁREA DE FLORESTA EM RECUPERAÇÃO \\
\hline 113 & 676802 & 9742296 & VEGETAÇÃO SECUNDÁRIA, ÁREA DE FLORESTA EM RECUPERAÇÃO \\
\hline 114 & 676637 & 9736742 & VEGETAÇÃO SECUNDÁRIA, ÁREA DE FLORESTA EM RECUPERAÇÃO \\
\hline
\end{tabular}

\section{2 - Características dos Solos}

Baseado nas características geomorfológicas, nos tipos de solos e na vegetação a região de estudo pode ser dividida em dois grandes grupos: "zona de várzea" e "zona de terra firme" (Figura 19). 


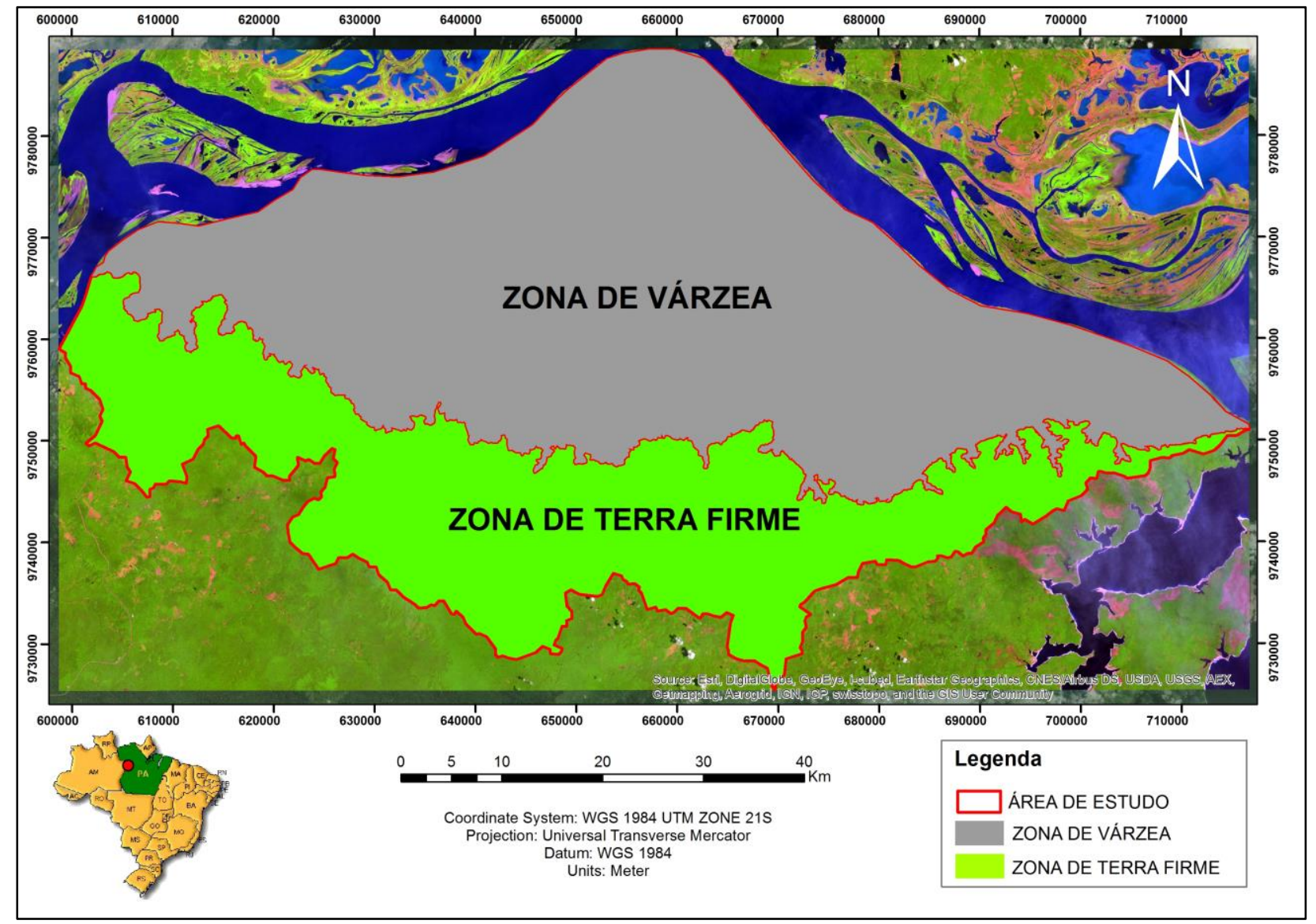

Figura 19 - Representação das duas principais zonas da área de estudo. (Imagem da várzea em outubro de 2011, retirada do INPE, sobreposta a imagem fornecida pelo BaseMap do Arcgis 10.1).

No geral, a maioria dos solos da zona de terra firme (TF) apresentam granulometria mais grossa que os solos da zona de várzea (Varz.), textura arenosa, coloração escura no horizonte superficial (enriquecido em matéria orgânica) e coloração bege amarelada (7,5YR- 10YR) ao longo do resto do perfil. Os latossolos são o tipo pedológico predominante nessa zona, mas também é possível observar em algumas porções da área manchas de argissolo, plintossolo, neossolo e cambissolo.

Os solos da zona de várzea apresentam granulometria mais fina que os da zona de terra firme (argilita, silte, areia fina), textura argilosa, coloração escura no topo do perfil, tons acinzentados (variação de N7/ a N4/) ao longo do perfil (até 1 metros de profundidade) e diversas concreções petroplínticas próximas a superfície. Os gleissolos são o tipo de solo mais representativo dessa zona que passa grande parte do ano submersa; porém em algumas porções é possível observar manchas de plintossolos.

\subsection{1 - Classificação Textural}

A classificação textural é um importante parâmetro na classificação dos solos, na diferenciação entre seus horizontes e nos empregos/utilização que podem ser dados ao solo. 
A grande maioria das análises de granulometria e classificação textural dos solos da região foram feitas com base em observações de campo; mas algumas amostras coletadas em campo foram submetidas a análises granulométricas em laboratório para uma análise mais precisa dessas características.

Os resultados dessas análises estão apresentados na tabela abaixo (Tabela 3); podemos notar que para duas amostras (005: 60-80 e 037:0-20) não foi possível quantificar a proporção de silte no solo (essas amostras apresentam uma quantidade de silte menor que o limite de detecção da técnica utilizada) e em outras duas amostras (068: 0-20 e 068:20-40) as quantidades de argila e silte, com maior porcentagem de argila, ultrapassam os $100 \%$, sugerindo que a quantidade de argila foi sobre estimada. 
Tabela 3 - Distribuição granulométrica (\% de argila, silte e areia) e classificação textural correspondente, segundo Lemos e Santos (1996), das amostras mais representativas dos tipos de solos da área de estudo. Em verde destacam-se as amostras da zona de terra firme, com textura predominante areia-franca e em cinza são apresentadas as amostras da zona de várzea, que possuem textura argilosa em sua maioria. (LQ: limite de quantificação ; A-F: AREIA-FRANCA, F-A: FRANCO-ARENOSA, F-S: FRANCO-SILTOSA, F-A-Arg: FRANCO-ARGILA-ARENOSA, F: FRANCO, Arg: ARGILA, FArg: FRANCO-ARGILOSA, M-Arg: MUITO ARGILOSA).

\begin{tabular}{|c|c|c|c|c|c|c|}
\hline \multirow{3}{*}{ AMOSTRA } & \multirow{3}{*}{ ARGILA } & \multirow{3}{*}{\multicolumn{2}{|c|}{$\begin{array}{c}\text { laboratório } \\
\text { AREIA }\end{array}$}} & \multicolumn{3}{|c|}{ campo } \\
\hline & & & & \multicolumn{2}{|c|}{ CLASSIFICAÇÃO TEXTURAL } & \multirow{2}{*}{ AREA } \\
\hline & & & & laboratório & campo & \\
\hline PONTO 005: 0-20 & 10,6 & 9,3 & 80,1 & $\mathrm{~A}-\mathrm{F}$ & $A-F$ & $\mathrm{TF}$ \\
\hline PONTO 005: 60-80 & 20,4 & $<\mathrm{LQ}$ & 79,6 & $\mathrm{~A}-\mathrm{F}$ & $A-F$ & TF \\
\hline PONTO 006: 0-20 & 21,6 & 15,0 & 63,4 & $\overline{A-F}$ & $A-F$ & TF \\
\hline PONTO 006: 40-60 & 18,0 & 5,2 & 76,7 & F-A & $\mathrm{F}-\mathrm{A}$ & TF \\
\hline PONTO 006: 80-100 & 22,7 & 2,9 & 74,4 & F-A-Arg & F-A-Arg & TF \\
\hline PONTO 032: 0-20 & 14,5 & 10,6 & 74,9 & $A-F$ & $A-F$ & TF \\
\hline PONTO 037: 20-40 & 27,6 & $<\mathrm{LQ}$ & 72,4 & F-A & F-A & TF \\
\hline PONTO 037: 100-120 & 22,0 & 1,2 & 76,9 & $\mathrm{~F}-\mathrm{A}$ & F-A & TF \\
\hline PONTO 038: 0-20 & 30,5 & 29,5 & 40,1 & F-A-Arg & F-A & TF \\
\hline PONTO 038: 100-120 & 11,7 & 20,9 & 67,4 & $\mathrm{~F}-\mathrm{A}$ & $\mathrm{F}-\mathrm{A}$ & TF \\
\hline PONTO 045: 0-40 & 18,8 & 4,1 & 77,0 & $A-F$ & $A-F$ & TF \\
\hline PONTO 045: 100-120 & 18,0 & 14,9 & 67,1 & F-A & F-A & $\mathrm{TF}$ \\
\hline PONTO 073: 0-20 & 16,8 & 0,7 & 82,5 & $A-F$ & $A-F$ & TF \\
\hline PONTO 073: 20-50 & 12,7 & 2,9 & 84,5 & $A-F$ & $A-F$ & TF \\
\hline PONTO 063: 0-20 & 60,2 & 8,4 & 31,4 & Arg & Arg & Varz \\
\hline PONTO 068: 0-20 & 75,7 & 32,8 & $<\mathrm{LQ}$ & Arg & $\operatorname{Arg}$ & Varz \\
\hline PONTO 068: $20-40$ & 78,4 & 36,4 & $<\mathrm{LQ}$ & $\operatorname{Arg}$ & Arg & Varz \\
\hline PONTO 069: 0-20 & 50,0 & 38,9 & 11,1 & Arg & Arg & Varz \\
\hline PONTO 069: 20-40 & 26,1 & 25,0 & 48,9 & $\mathrm{~F}$ & $\mathrm{~F}$ & Varz \\
\hline PONTO 071: 0-20 & 44,3 & 29,8 & 25,9 & $\operatorname{Arg}$ & Arg & Varz \\
\hline PONTO 071: 20-40 & 53,5 & 25,5 & 21,0 & Arg & Arg & Varz \\
\hline PONTO 081: 0-30 & 15,3 & 47,5 & 37,1 & $\mathrm{FS}$ & $\mathrm{FS}$ & Varz \\
\hline PONTO 081: 30-100 & 35,2 & 5,8 & 59,0 & F-A-Arg & F-A-Arg & Varz \\
\hline PONTO 107: 0-40 & 42,8 & 19,9 & 37,3 & Arg & Arg & Varz \\
\hline PONTO 107: 40-70 & 55,4 & 17,3 & 27,3 & Arg & Arg & Varz \\
\hline PONTO 110: 0-40 & 62,5 & 17,0 & 20,5 & M-Arg & M-Arg & Varz \\
\hline PONTO 110: 40-70 & 24,6 & 22,1 & 53,4 & F-A-Arg & F-A-Arg & Varz \\
\hline PONTO 110: 70-100 & 61,2 & 14,7 & 24,1 & M-Arg & M-Arg & Varz \\
\hline
\end{tabular}

Os resultados dessas análises acabaram confirmando as estimativas de campo; apenas o resultado obtido para amostra 038 entre 0 e $20 \mathrm{~cm}$ que apresentou uma distribuição granulométrica levemente divergente da classificação textural realizada no campo. Estes resultados confirmam a qualidade das observações texturais realizadas no campo sobre a totalidade dos horizontes descritos.

Com base nesses dados pode-se dizer que os solos da zona de terra firme apresentam uma predominância de granulometria mais grossa (tamanho areia) e os solos da zona de várzea uma predominância de uma granulometria mais fina (tamanho argila) (Figura 20). 


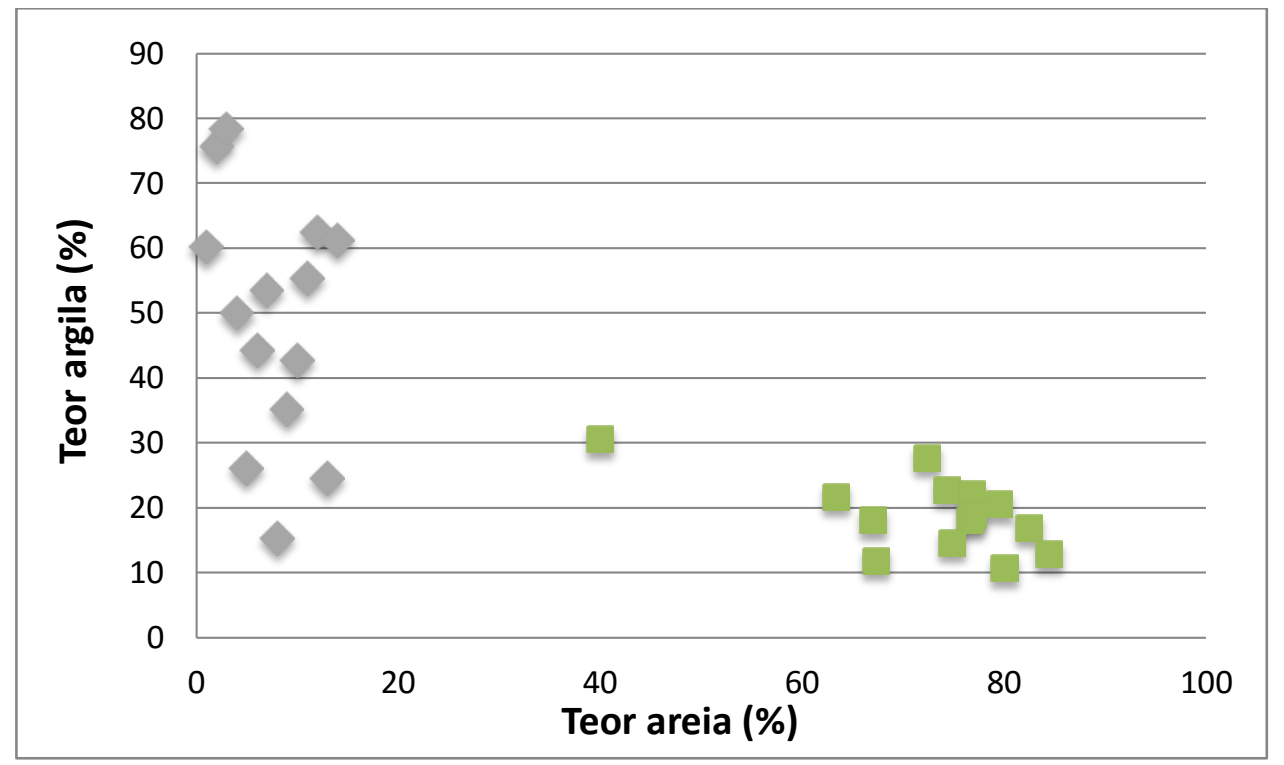

Figura 20- Distribuição dos teores de areia contra teores de argila de uma seleção de amostras de solos da Terra Firma (quadrado verde) e da área de Várzea (losango cinza).

\subsection{2 - Mineralogia dos solos (Análise por difratometria de Raios-X)}

\subsubsection{1 - Hipótese: Composição esperada:}

Os argilominerais são indicadores de origem, intensidade de intemperismo, além de serem marcadores do tempo das rochas sedimentares, sedimentos marítimos e fluviais (Guyot et al. 2007).

Como já mencionado, o Lago Grande de Curuai sofre influência direta do rio Amazonas e por esse motivo vários dos argilominerais transportados/carregados pelas águas do rio podem ser incorporados aos solos da zona de várzea. No rio Amazonas observa-se minerais provenientes dos perfis lateríticos da região amazônica (caulinita, gibbsita, ilita, óxidos e hidróxidos de ferro, anatásio, entre outros), porém também observam-se minerais provenientes da Cordilheira dos Andes, com menor grau de intemperismo, como argilominerais 2:1, feldspato (Gibbs, 1967; Guyot et al., 2007; Guimarães et al., 2013; Bouchez et al., 2014).

Os estudos realizados na Bacia Amazônica mostram que a maior parte (quase 90\%) da carga suspensa do rio Amazonas (MES - material em suspenção) vem dos Andes (Gibbs, 1967; Meade et al., 1985; Guyot, 1993; Filizola, 1999 e 2003; Guyot et al., 2007).

As águas do rio Amazonas são o resultados da mistura de águas provenientes de diversas localidades (cordilheira, escudos), Guyot et al. (2007) constatou que os sedimentos dos rios andinos apresentam uma assinatura típica comum com alto teor de ilita e clorita (> 50\%); já os rios da região dos Escudos, que apresentam solos mais espessos, antigos e lixiviados, transportam sedimentos em estágios mais avançados de intemperismo. Nos MES das planícies de 
inundação do rio Amazonas foi identificado um aumento de esmectita decorrente da erosão dos bancos laterais e da drenagem dos tributários, como por exemplo, na estação de Óbidos.

De forma geral, considerando-se toda a bacia hidrográfica da Amazônia, Guyot et al. (2007) elaboram um modelo com três principais fontes de minerais: i) domínio escudo (Brasileiro e Guiana) com altos teores de caulinita, ii) domínio Andino com a ilita e clorita predominante, além dos altos teores de esmectita. iii) rio Solimões com a prevalência de esmectitas.

Apesar da heterogeneidade de componentes minerais transportados pelo rio Amazonas, os perfis e horizontes de solos avaliados na bacia Amazônica (por diversos pesquisadores em seus trabalhos) não apresentaram grandes oscilações quanto à mineralogia (Fritsch et al., 1998; Lima, 2001; Fritsch et al., 2005; Guyot et al., 2007; Horbe et al., 2007; Macedo, 2009; Frish et al., 2009; Silva et al., 2011).

Como base nesses conhecimentos sobre a variabilidade da composição mineral do rio Amazonas, das diferentes fontes e origens de minerais e com o entendimento dos processos de formação da Bacia e da ciclicidade dos pulsos de inundações nas planícies Amazônicas, é possível montar uma lista de minerais esperados nos solos da área de estudo: quartzo, oxidoshidróxidos de ferro, caulinita, gibbsita, ilita e esmectita.

\subsubsection{2 - Resultados}

Os resultados obtidos por difratometria de raios-X das amostras de solos coletadas nas zonas de terra firme e de várzea sobre a fração total (TFSA) e argila (separação por centrifugação) estão apresentados na Tabela 4.

As Figura 21 e Figura 22 representam difratogramas de amostras características da assembleia mineralógica encontrada nos solos da zona de terra firma e de várzea, respectivamente. 


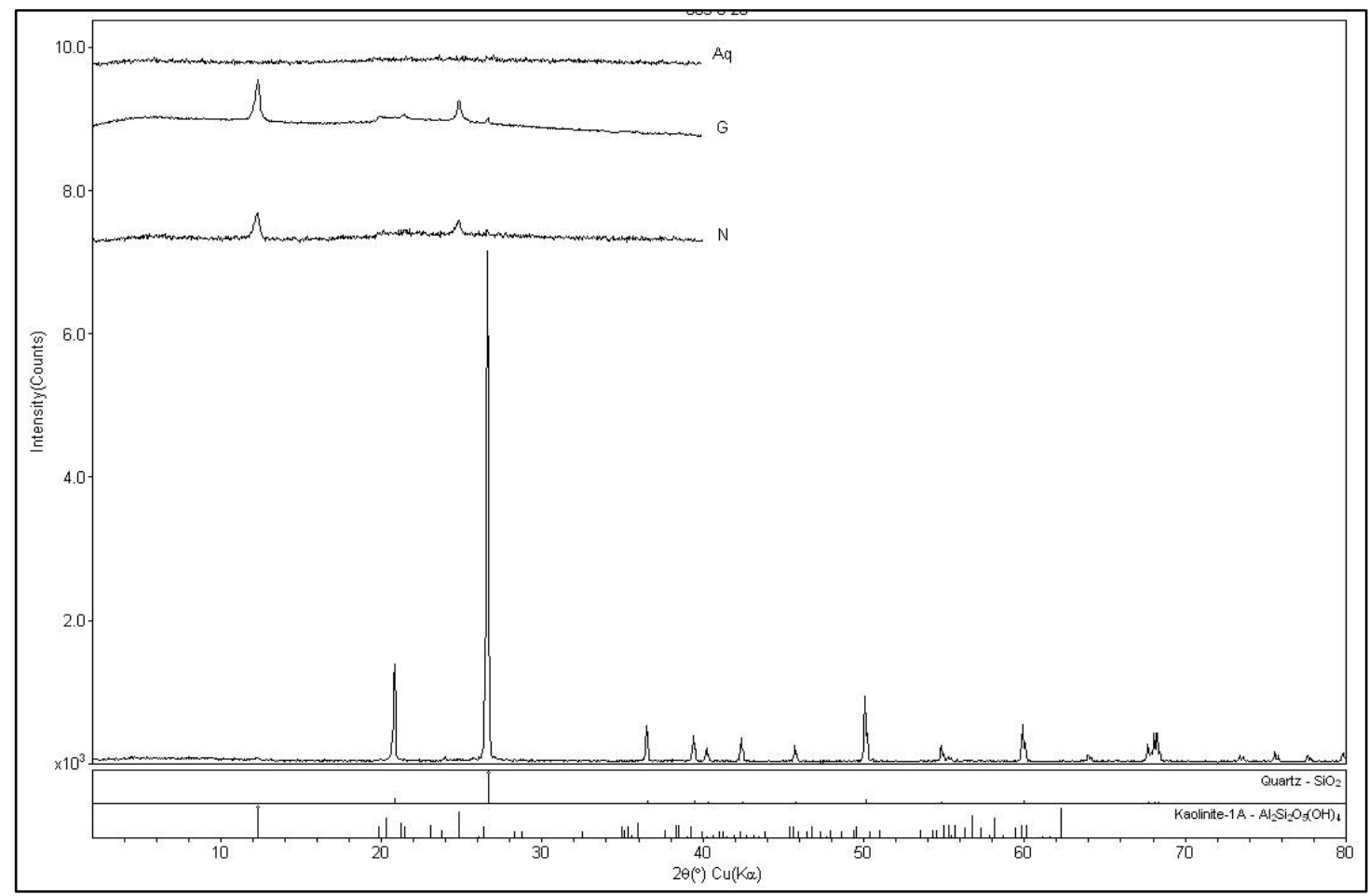

Figura 21 - Difratograma representativo da mineralogia típica dos solos de terra firme (DRX da amostra 005: 0-20) (T: fração TFSA, N: fina - argila, G: glicolada, Aq: aquecida).

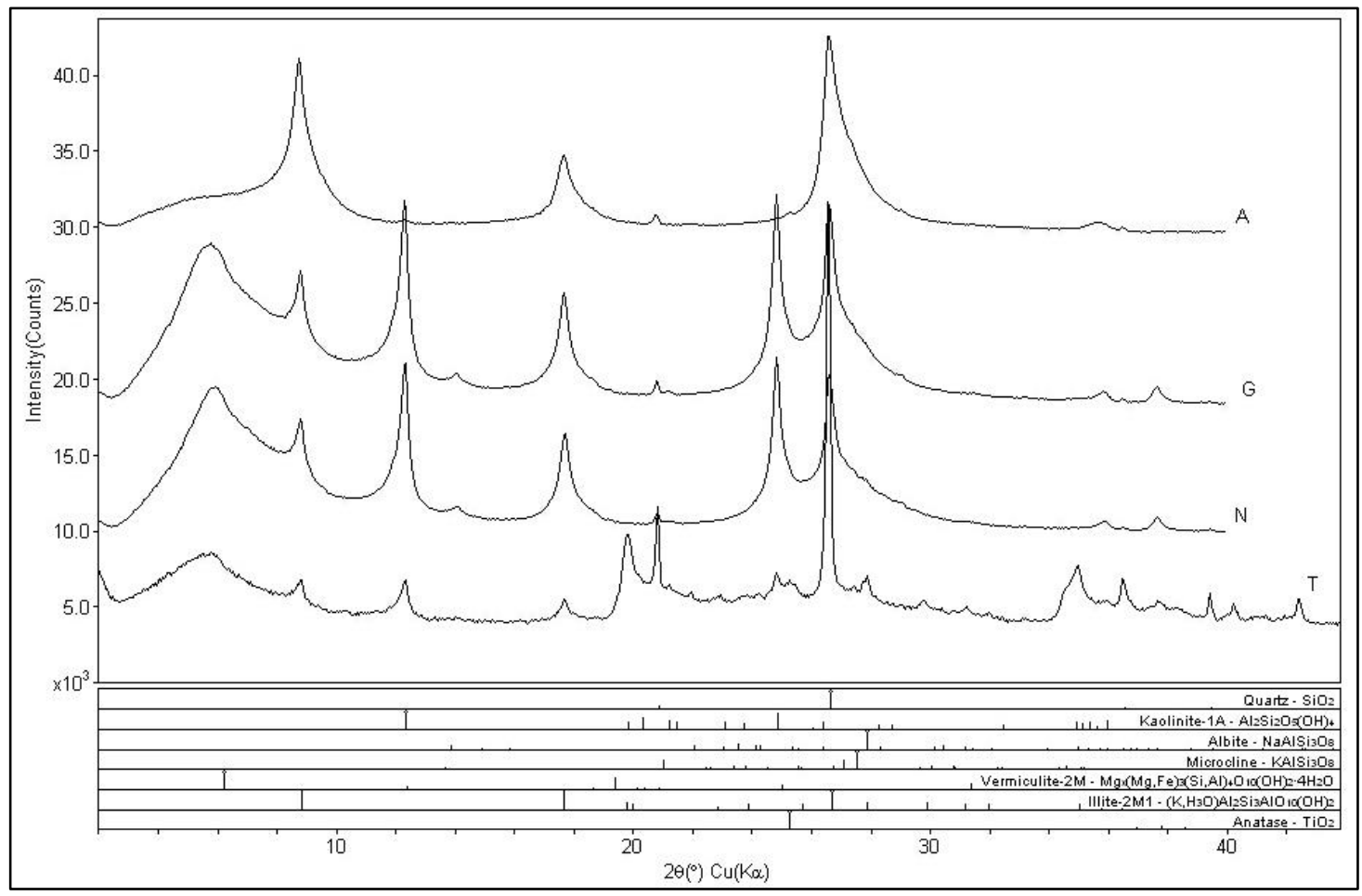

Figura 22 - Difratograma representativo da mineralogia típica dos solos de várzea (DRX da amostra 068: 20-40) (T: fração TFSA, N: fina - argila, G: glicolada, A: aquecida). 
Tabela 4 - Mineralogia das amostras total (TFSA) e fração argila de coletadas na zona de terra firme e de várzea .

\begin{tabular}{|c|c|c|c|c|c|c|c|c|c|c|c|c|c|c|c|c|c|c|c|c|c|}
\hline \multirow{2}{*}{ AMOSTRA } & \multirow{2}{*}{$\begin{array}{l}\text { LOCAL DE COLETA/ } \\
\text { VEGETAÇÃO }\end{array}$} & \multirow{2}{*}{$\begin{array}{l}\text { TIPO DE } \\
\text { SOLO }\end{array}$} & \multirow{2}{*}{ AREA } & \multirow{2}{*}{\multicolumn{2}{|c|}{$\begin{array}{l}\text { Qzo } \\
\text { AL ARG }\end{array}$}} & \multirow{2}{*}{\multicolumn{2}{|c|}{$\begin{array}{c}\text { Caol. } \\
\text { TOTAL ARGILA }\end{array}$}} & \multicolumn{2}{|c|}{ Gib. } & \multirow{2}{*}{\multicolumn{2}{|c|}{$\begin{array}{c}\text { llita } \\
\text { TOTAL ARGIIA }\end{array}$}} & \multirow{2}{*}{\multicolumn{2}{|c|}{ Verm. }} & \multicolumn{2}{|c|}{ Nont. } & \multicolumn{2}{|c|}{ Alb. } & \multirow{2}{*}{\multicolumn{2}{|c|}{$\begin{array}{c}\text { Microc. } \\
\text { TOTAL ARGIIA }\end{array}$}} & \multicolumn{2}{|c|}{ Anat. } \\
\hline & & & & & & & & TOTAL & ARGILA & & & & & & ARGILA & TOTAL & ARGILA & & & & ARGILA \\
\hline $\begin{array}{l}\text { PONTO 005: 0-20 } \\
\text { PONTO 005: 60-80 }\end{array}$ & $\begin{array}{l}\text { FLORESTA DESMATADA- ROCGA DE } \\
\text { MANDIOCAA }\end{array}$ & LAT. AM. & TF & $\mathrm{M}$ & $m$ & $m$ & $\mathrm{M}$ & - & - & - & - & - & - & - & - & - & - & - & - & - & - \\
\hline PONTO 006: 0-20 & & & TF & $M$ & $\mathrm{~m}$ & $\mathrm{~m}$ & $M$ & - & - & - & - & - & - & - & - & - & - & - & - & - & - \\
\hline PONTO 006: 40-60 & CAMPO SUJO - CAPIM NATIVO & LAT. AM. & TF & M & $\mathrm{m}$ & $\mathrm{m}$ & M & - & - & - & - & - & - & - & - & - & - & - & - & - & - \\
\hline PONTO 006: 80-100 & & & TF & M & $\mathrm{m}$ & $\mathrm{m}$ & M & - & - & - & - & - & - & - & - & - & - & - & - & - & - \\
\hline PONTO 032: 0-20 & SERRA & LAT. VERM. & TF & $\mathrm{M}$ & $\mathrm{m}$ & $\mathrm{m}$ & $M$ & $\mathrm{~m}$ & $\mathrm{M}$ & - & - & - & - & - & - & - & - & - & - & - & - \\
\hline PONTO 037: 20-40 & FLORESTA DESMATADA- PASTO & & TF & M & $\mathrm{m}$ & $\mathrm{m}$ & M & - & - & - & - & - & - & - & - & - & - & - & - & - & - \\
\hline PONTO 037: 100-120 & FLORESTA DESMATADA - PASTO & LAT. AM. & $\mathrm{TF}$ & M & $\mathrm{m}$ & $\mathrm{m}$ & M & - & - & - & - & - & - & - & - & - & - & - & - & - & - \\
\hline PONTO 038: 0-20 & & & TF & M & $\mathrm{m}$ & $\mathrm{m}$ & M & - & - & - & - & - & - & - & - & - & - & - & - & - & - \\
\hline PONTO 038: $100-120$ & FLORESTA VIRGEM & LAT. AM. & TF & M & $\mathrm{m}$ & $\mathrm{m}$ & M & - & - & - & - & - & - & - & - & - & - & - & - & - & - \\
\hline PONTO 045: 0-40 & EIOPESTA VIPGEM & & TF & M & $\mathrm{m}$ & $\mathrm{m}$ & M & - & - & - & - & - & - & - & - & - & - & - & - & - & - \\
\hline PONTO 045: 100-120 & FLORESTA VIRGEM & LAT. AM. & $\mathrm{TF}$ & M & $\mathrm{m}$ & $\mathrm{m}$ & M & - & - & - & - & - & - & - & - & - & - & - & - & - & - \\
\hline PONTO 112: 0-20 & & & TF & M & $\mathrm{m}$ & $\mathrm{m}$ & M & - & - & - & - & - & - & - & - & - & - & - & - & - & \\
\hline PONTO 112: 20-35 & FLORESTA DESMATADA- ROCA DE & & TF & M & $\mathrm{m}$ & $\mathrm{m}$ & M & - & - & - & - & - & - & - & - & - & - & - & - & - & - \\
\hline PONTO 112: 35-50 & MANDIOCA & LAT. AM. & TF & M & $\mathrm{m}$ & $\mathrm{m}$ & M & - & - & - & - & - & - & - & - & - & - & - & - & - & - \\
\hline PONTO 112: 50-70: & & & TF & M & $\mathrm{m}$ & $\mathrm{m}$ & M & - & - & - & - & - & - & - & - & - & - & - & - & - & - \\
\hline PONTO 113: 0-20 & & & TF & M & $\mathrm{m}$ & $\mathrm{m}$ & M & - & - & - & - & - & - & - & - & - & - & - & - & - & - \\
\hline PONTO 113: 20-35 & FLORESTA DESMATADA - ROCGA DE & & TF & M & $\mathrm{m}$ & $\mathrm{m}$ & M & - & - & - & - & - & - & - & - & - & - & - & - & - & - \\
\hline PONTO 113: $35-50$ & 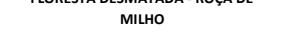 & LAT. AM. & TF & M & $\mathrm{m}$ & $\mathrm{m}$ & M & - & - & - & - & - & - & - & - & - & - & - & - & - & - \\
\hline PONTO 113: 50-64 & & & TF & M & $\mathrm{m}$ & $\mathrm{m}$ & M & - & - & - & - & - & - & - & - & - & - & - & - & - & - \\
\hline PONTO 114: 0-20 & & & TF & M & $\mathrm{m}$ & $\mathrm{m}$ & M & - & - & - & - & - & - & - & - & - & - & - & - & - & - \\
\hline PONTO 114: 20-30 & 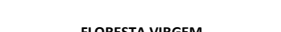 & & TF & M & $\mathrm{m}$ & $\mathrm{m}$ & M & - & - & - & - & - & - & - & - & - & - & - & - & - & - \\
\hline PONTO 114: 30-40 & FLORESTA VIRGEM & LAT. AM. & TF & M & $\mathrm{m}$ & $\mathrm{m}$ & M & - & - & - & - & & - & - & - & - & - & - & - & - & - \\
\hline PONTO 114: 40-56 & & & TF & M & $\mathrm{m}$ & $\mathrm{m}$ & M & - & - & - & - & - & - & - & - & - & - & - & - & - & - \\
\hline PONTO 062: 0-10 & ZONA DE VARZZEA - pastagem & GLEl. HÁP. & varz. & $\mathrm{M}$ & $\mathrm{m}$ & $\mathrm{m}$ & M & - & - & $\mathrm{m}$ & $M$ & - & - & - & - & - & - & - & - & - & - \\
\hline PONTO 063: 0-20 & ZONA DE VARZEA/VEG. RASTERA & GLEI. HÁP. & Varz. & $M$ & $\mathrm{~m}$ & $\mathrm{~m}$ & $\mathrm{M}$ & - & - & $\mathrm{m}$ & $M$ & - & - & $\mathrm{m}$ & M & $\mathrm{m}$ & $\mathrm{m}$ & $\mathrm{m}$ & $\mathrm{m}$ & $\mathrm{m}$ & M \\
\hline PONTO 068: 0-20 & ZONA DE YABZEAYYEG RASTEPA & 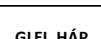 & Varz. & M & $\mathrm{m}$ & $\mathrm{m}$ & $\mathrm{M}$ & - & - & $\mathrm{m}$ & $M$ & M & M & & - & $\mathrm{m}$ & $\mathrm{m}$ & $\mathrm{m}$ & $\mathrm{m}$ & $\mathrm{m}$ & $\mathrm{m}$ \\
\hline PONTO 068: 20-40 & ZONA DE VAREEA VEGG. RASTERA & GLEl. HAP. & Varz. & M & $\mathrm{m}$ & $\mathrm{m}$ & M & - & - & $\mathrm{m}$ & M & M & M & - & - & $\mathrm{m}$ & $\mathrm{m}$ & $\mathrm{m}$ & - & $\mathrm{m}$ & $\mathrm{m}$ \\
\hline PONTO 069: 0-20 & ZONA DE VARZZEA/VEG. RASTERA & & Varz. & $\mathrm{M}$ & $\mathrm{m}$ & $\mathrm{m}$ & M & - & - & $\mathrm{m}$ & M & $\mathrm{m}$ & $M$ & & - & $\mathrm{m}$ & $\mathrm{m}$ & $\mathrm{m}$ & $\mathrm{m}$ & $\mathrm{m}$ & $\mathrm{m}$ \\
\hline PONTO 069: 20-40 & ZONA DE VARZEA/VEGG RASTERA & GLEI. HÁP. & Varz. & M & $\mathrm{m}$ & $\mathrm{m}$ & M & - & - & $\mathrm{m}$ & M & $\mathrm{m}$ & M & - & - & $\mathrm{m}$ & $\mathrm{m}$ & $\mathrm{m}$ & $\mathrm{m}$ & $\mathrm{m}$ & $\mathrm{m}$ \\
\hline PONTO 071: 0-20 & 7 & Sure ú́ & Varz. & M & $\mathrm{m}$ & $\mathrm{m}$ & M & - & - & $\mathrm{m}$ & M & - & - & $\mathrm{m}$ & M & $\mathrm{m}$ & $\mathrm{m}$ & $\mathrm{m}$ & $\mathrm{m}$ & $\mathrm{m}$ & $\mathrm{m}$ \\
\hline PONTO 071: $20-40$ & ZONA DE VARZZEA/VEG. RASTERRA & GLEI. HÁP. & Varz. & M & $\mathrm{m}$ & $\mathrm{m}$ & M & - & - & $\mathrm{m}$ & M & - & - & $\mathrm{m}$ & M & $\mathrm{m}$ & $\mathrm{m}$ & $\mathrm{m}$ & $\mathrm{m}$ & $\mathrm{m}$ & $\mathrm{m}$ \\
\hline PONTO 073: 0-20 & 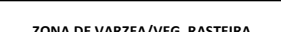 & Ойни́ & Varz. & $\mathrm{M}$ & $\mathrm{m}$ & $\mathrm{m}$ & M & - & - & $\mathrm{m}$ & $\mathrm{m}$ & - & - & - & - & - & - & - & - & $\mathrm{m}$ & $\mathrm{m}$ \\
\hline PONTO 073: 20-50 & 2ONA DE VARZEARNGGG RASEERA & GLEL. HAP. & Varz. & M & $\mathrm{m}$ & $\mathrm{m}$ & M & - & - & $\mathrm{m}$ & $\mathrm{m}$ & $\mathrm{m}$ & $\mathrm{m}$ & & - & - & - & - & - & $\mathrm{m}$ & $\mathrm{m}$ \\
\hline PONTO 081: 0-30 & & & Varz. & M & $\mathrm{m}$ & $\mathrm{m}$ & M & - & - & - & - & - & - & - & - & - & - & - & - & $\mathrm{m}$ & $\mathrm{m}$ \\
\hline PONTO 081: $30-100$ & Floresta proxima a a ambiente de Várzea & PLINT. & varz. & M & M & M & M & - & - & $\mathrm{m}$ & $\mathrm{m}$ & - & - & - & - & - & - & - & - & $\mathrm{m}$ & $\mathrm{m}$ \\
\hline PONTO 107: 0-40 & 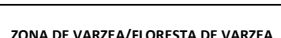 & PUNT & Varz. & M & $\mathrm{m}$ & $\mathrm{m}$ & $\mathrm{m}$ & - & - & $\mathrm{m}$ & $\mathrm{m}$ & $\mathrm{m}$ & $\mathrm{m}$ & - & - & - & - & - & - & $\mathrm{m}$ & $\mathrm{m}$ \\
\hline PONTO 107: 40-70 & & & Varz. & M & $\mathrm{m}$ & M & M & - & - & $\mathrm{m}$ & $\mathrm{m}$ & $\mathrm{m}$ & $\mathrm{m}$ & - & - & - & - & $\mathrm{m}$ & $\mathrm{m}$ & $\mathrm{m}$ & $\mathrm{m}$ \\
\hline PONTO 110: 0-40 & & & Varz. & $\mathrm{M}$ & $\mathrm{m}$ & $\mathrm{M}$ & $\mathrm{M}$ & - & - & $\mathrm{m}$ & $\mathrm{m}$ & $\mathrm{m}$ & $\mathrm{m}$ & & - & - & - & $\mathrm{m}$ & $\mathrm{m}$ & $\mathrm{m}$ & $\mathrm{m}$ \\
\hline PONTO 110: 40-70 & ZONA DE VARZEA/FLORESTA DE VARZEA & GLEI. HÁP. & varz. & M & $\mathrm{m}$ & M & M & - & - & $\mathrm{m}$ & $\mathrm{m}$ & $\mathrm{m}$ & $\mathrm{m}$ & - & - & - & - & $\mathrm{m}$ & $\mathrm{m}$ & $\mathrm{m}$ & $\mathrm{m}$ \\
\hline PONTO 110: 70-100 & & & varz. & M & $\mathrm{m}$ & M & $\mathrm{M}$ & - & - & $\mathrm{m}$ & $\mathrm{m}$ & $\mathrm{m}$ & $\mathrm{m}$ & - & - & - & - & $\mathrm{m}$ & $\mathrm{m}$ & $\mathrm{m}$ & $\mathrm{m}$ \\
\hline PONTO 111: 0-10 & & & Varz. & M & $\mathrm{m}$ & $\mathrm{m}$ & $\mathrm{M}$ & - & - & $\mathrm{m}$ & M & & - & & - & - & - & - & - & - & - \\
\hline PONTO 111: 10-20 & ZONA DE VARZEA - pastagem & GLEI. & varz. & M & $\mathrm{m}$ & $\mathrm{m}$ & M & - & - & $\mathrm{m}$ & M & - & - & - & - & - & - & - & - & - & - \\
\hline PONTO 111: 20-35 & & & Varz. & M & $\mathrm{m}$ & $\mathrm{m}$ & M & - & - & $\mathrm{m}$ & M & & - & - & - & - & - & - & - & - & - \\
\hline PONTO 65: 0-15 & ZONA DE VARZEA/FLORESTA DE VARZEA & PLINT. & Varz. & M & $\mathrm{m}$ & M & M & - & - & $\mathrm{m}$ & $\mathrm{m}$ & $\mathrm{m}$ & $\mathrm{m}$ & - & - & - & - & $\mathrm{m}$ & $\mathrm{m}$ & $\mathrm{m}$ & $\mathrm{m}$ \\
\hline
\end{tabular}

\section{Legenda:}

\#- Escala de abundância estima $\operatorname{com} \underline{M}$ - mineral Maior/mais abundante; $\underline{m}$-mineral menor/menos abundate $e^{\prime-} \cdot$ ausência de mineral

\section{\#- TOTAL: amostras total} (TFSA) e ARGILA: fração argila,

\#-Minerais: Qzo: quartzo, Caol.: Caulinita, Gib. Gibbsita, Ilita: Ilita, Verm.:

Vermiculita, Nont.: Nontronita, Alb.: Albita, Micrc.

Microcline, Anat.: Anatásio). 
Os solos da região de terra firme apresentam basicamente quartzo e caulinita; quartzo $\left(\mathrm{SiO}_{2}\right)$ como constituinte maior $(\mathrm{M})$ - mineral mais abundante - na fração total do solo e a caulinita $\left(\mathrm{Al}_{2} \mathrm{Si}_{2} \mathrm{O}_{5}(\mathrm{OH})_{4}\right)$ como mineral predominante na fração argila Tabela 4 e Figura 21. Porém algumas amostras apresentam uma mineralogia um pouco diferente do comum para a área:

○ A amostra 032 foi coletada em uma serra na porção sudoeste da área de estudo e além de quartzo e caulinita ela também apresenta gibbsita $\left(\mathrm{Al}(\mathrm{OH})_{3}\right.$, ) em sua composição. A gibbisita é gerada por intemperismo químico (com intensa lixiviação) de rochas ricas em feldspatos ou outros minerais aluminosos em clima quente e úmido, e é um dos principais componentes da bauxita. A presença de bauxita no solo da região pode ser correlacionada ao intemperismo dos arenitos arcoseanos que compõem a Formação Alter do Chão. A região de coleta da amostra já esteve requerida junto ao DNPM pela empresa VALE e segundo pesquisas foi definido um depósito de bauxita na região. Hoje em dia esse requerimento está sob a tutela da empresa Cowley Mineração Ltda.

○ A amostra 073 além da composição típica dos solos de terra firme apresenta ilita, vermiculita e anatásio. Essa amostra foi coletada em uma área de transição entre a zona de várzea e a zona de terra firme; durante certos períodos essa área fica sobre influência de grandes pulsos de inundação, sendo está a hipótese que busca justificar a presença de ilita e vermiculita que são incomuns na zona de terra firme. Estes minerais foram provavelmente adicionados ao solo da área após pulsos de inundação que transportavam esses minerais como material em suspensão e estes acabaram se depositando e incorporando o solo da área. O anatásio $\left(\mathrm{TiO}_{2}\right)$ apesar de ser muito resistente ao intemperismo só foi observado nos solos de várzea ou nas zonas de transição (zonas que são afetadas em grandes períodos de cheia) e por isso também é associado a mesma justificativa para a presença de ilita e vermiculita nessa área (Ferreira et al., 1999; Kotschoubey et al.,1999; Guyot et al., 2007).

○ A amostra 081 tem composição mineralógica semelhante à amostra 073, além da composição típica dos solos de terra firme, quartzo e caulinita, a amostra 081 apresenta ilita e anatásio em sua composição. Essa amostra também foi coletada em uma área de transição entre a zona de várzea e a zona de terra firme e a hipótese para essa mineralogia é a mesma descrita acima; esses minerais foram adicionados ao solo da área por meio dos pulsos de inundação que afetam a região.

Já os solos do ambiente de várzea apresentam uma assembléia mineralogica um pouco mais diversificada, além de apresentarem o mesmo padrão de concentração do quartzo 
(predominante na amostra total) e da caulinita (predominante na fração argila) que as amostras de terra firme, as amostras de várzea apresentam minerais como ilita, nontronita, albita, microclínio, anatásio, vermiculita (Figura 22).

Considerando o funcionamento da área de Várzea e a literatura podemos emitir a hipótese que esse minerais são também resultados de sedimentos provenientes dos Escudos Cristalinos e da Cadeia Andina, que são transportados pelo Rio Amazonas e adicionados ao solo da várzea. Essa hipótese foi confrontada as análises feitas pela equipe do Projeto, mais especificamente no quadro do projeto de iniciação científica (PIBIC) da aluna Valessa Araujo intitulado "Mineralogia e Geoquímica de Sedimentos na Várzea Lago Grande de Curuai". Araujo et al., 2014 analisaram a natureza da sedimentação da Várzea de Curuai e dos materiais que por ela circulam com base em coletas de testemunhos de sedimento de $50 \mathrm{~cm}$ (coletados na enchente em 2014 - Maio) e MES coletados em diferentes locais da várzea e períodos do ano. Os resultados confirmaram a presença de vários minerais carregados pelas águas a montante da bacia (Solimões, Aamazonas) e assim estão de acordo com a literatura. Os sedimentos carregados pelas águas do lago são compostos por diversos minerais - muitos deles ausentes nos solos da região como ilita, caulinita, ortoclásio, gibbsita, montmorilonita e interestraficados (a maioria destes minerais são argilominerais de tipo 2:1, formados em condição de bissialitização).

Além da identificação de diversos minerais compondo a fração argila dos solos da várzea, a difratometria de raios-X também apresenta outro dado que merece destaque, que é a presença de quartzo e caulinita, tanto na amostra total quanto nas frações argila, fato esse que sugere fortes processos de intemperismo físico e químico. Sabe-se que quartzo é um mineral resistente ao intemperismo e dificilmente se fragmenta em frações tão pequenas como a fração argila demonstrando assim os intensos processos intempéricos (químico e físico) ao qual foi submetido. Já a caulinita é um mineral comum na fração argila de solos de clima tropical, (minerais secundário associado os processo de monossialitização) e normalmente é resultado do intenso intemperismo dessa região podendo até ser o mineral dominante da amostra nessa fração (a caulinita é considerada um dos produtos finais do processo de intemperismo, sendo um dos últimos minerais secundários a se formar) (Lucas et al., 1993; Van Breemen e Buurman, 2002; Frish et al., 2009).

Com bases nos resultados obtidos até o momento, propõe-se um modelo conceitual pedológico simples. Com dois grandes tipos de solos:

- latossolos, caracterizado por textura arenosa e mineralogia típica composta por quartzo e caulinita; e 
- gleissolos, caracterizado por textura argilosa e mineralogia típica composta por quarto, caulinita, ilita, vermiculita e anatásio.

Nas áreas de Terra Firme, encontram-se quase que exclusivamente latossolos, enquanto nas áreas de Várzea predominam gleissolos. Esse modelo pedológico conceitual já era esperado e é corroborado pelas bases bibliográficas do trabalho (Tabela 5).

Tabela 5 - Apresentação dos dados obtidos até o momento para a elaboração do modelo conceitual pedológico da região.

\begin{tabular}{|l|c|c|}
\hline ZONAS & ZONA DE TERRA FIRME & ZONA DE VÁRZEA \\
\hline LITOLOGIA & Fm. ALTER DO CHÃO & DEPÓSITOS DE ALUVIÃO \\
\hline PERÍODO & TERCIÁRIO & QUATERNÁRIO \\
\hline GRANULOMETRIA & AREIA & ARGILA/SILTE \\
\hline MINERALOGIA & MIN. SIMPLES (QTZ,CAU) & MIN. COMPLEXA (QTZ, CAU, 2:1) \\
\hline TIPO DE SOLO & LATOSSOLOS & GLEISSOLOS \\
\hline
\end{tabular}

\section{3 - Geoquímica e Perda ao Fogo}

As análises de elementos maiores em teores de óxidos e a perda ao fogo (PF) estão compiladas na Tabela 6, na qual podemos observar o fechamento do balanço químico entre 95 e $105 \%$, números esses considerados como aceitáveis e confiáveis. 
Tabela 6- Composição quimica em óxidos das amostras analisadas em laboratório, e valor da perda ao fogo. $O$ balanço de óxidos apresenta valores confiaveis, todos com resultados próximo ao $100 \%$. Na tabela tambem é apresentada o somatório de bases $\left(\mathrm{CaO}+\mathrm{Na}_{2} \mathrm{O}+\mathrm{K}_{2} \mathrm{O}\right)$ e a razão $\mathrm{CIA}\left(\mathrm{Al}_{2} \mathrm{O}_{3} / \mathrm{Al}_{2} \mathrm{O}_{3}+\right.$ bases $)$. $(\mathrm{Legenda}$ : TF $=$ Terra Firme; e VARZ = Várzea $)$.

\begin{tabular}{|c|c|c|c|c|c|c|c|c|c|c|c|c|c|c|c|}
\hline AMOSTRA & $\begin{array}{l}\text { LOCAL DE COLETA/ } \\
\text { VEGETAÇÃ̃o }\end{array}$ & TIPO DE SOLO & AREA & $\mathrm{CaO}$ & MgO & $\mathrm{Na} 2 \mathrm{O}$ & K2O & $\begin{array}{l}\text { SiO2 } \\
\text { em \% }\end{array}$ & $\mathrm{Fe} 2 \mathrm{O} 3$ & Al2O3 & TiO2 & $\mathrm{PF}$ & $\begin{array}{l}\text { TOTAL } \\
\text { em \% }\end{array}$ & $\begin{array}{c}\mathrm{CaO}+\mathrm{Na2O}+ \\
\mathrm{K} 2 \mathrm{O}\end{array}$ & CIA \\
\hline PONTO 005: 0-20 & FLORESTA DESMATADA - ROÇA DE & AT AM. $\mathrm{A}, \mathrm{C}$ & $\mathrm{TF}$ & 0,08 & 0,02 & 0,75 & 0,01 & 88,96 & 1,25 & 5,45 & 0,30 & 2,40 & 99 & 0,84 & 86,7 \\
\hline PONTO 005: 60-80 & MANDIOCA & LAT. AM. & $\mathrm{TF}$ & 0,19 & 0,02 & 0,52 & 0,01 & 85,16 & 1,70 & 8,05 & 0,42 & 2,25 & 98 & 0,72 & 91,8 \\
\hline PONTO 006: 0-20 & & & TF & 0,13 & 0,02 & 0,73 & 0,01 & 93,39 & 1,77 & 6,11 & 0,30 & 1,85 & 104 & 0,87 & 87,6 \\
\hline PONTO 006: 40-60 & CAMPO SUJO- CAPIM NATIVO & LAT. AM. & TF & 0,20 & 0,02 & 0,45 & 0,01 & 83,18 & 1,27 & 8,80 & 0,44 & 2,35 & 97 & 0,66 & 93,0 \\
\hline PONTO 006: 80-100 & & & $\mathrm{TF}$ & 0,07 & 0,02 & 0,39 & 0,01 & 82,95 & 1,45 & 9,85 & 0,44 & 2,25 & 97 & 0,47 & 95,5 \\
\hline PONTO 032: 0-20 & SERRA & LAT. VERM. & $\mathrm{TF}$ & 0,10 & 0,01 & 0,87 & 0,01 & 82,30 & 2,93 & 12,97 & 0,52 & 2,00 & 102 & 0,98 & 93,0 \\
\hline PONTO 037: 20-40 & FL ORESTA DESMATADA - PASTO & AT AM & $\mathrm{TF}$ & 0,14 & 0,02 & 0,72 & 0,01 & 89,20 & 1,36 & 5,10 & 0,62 & 4,50 & 102 & 0,87 & 85,4 \\
\hline PONTO 037: 100-120 & FLORESTA DESMATADA - PASTO & LAT. AM. & $\mathrm{TF}$ & 0,36 & 0,02 & 0,70 & 0,01 & 84,12 & 2,53 & 9,83 & 0,87 & 2,10 & 101 & 1,07 & 90,2 \\
\hline PONTO 038: 0-20 & FEORESTA VIRGEM & AT & $\mathrm{TF}$ & 0,09 & 0,02 & 0,58 & 0,01 & 85,80 & 0,82 & 9,17 & 0,57 & 5,80 & 103 & 0,68 & 93,1 \\
\hline PONTO 038: 100-120 & FLORESTA VIRGEM & LAT. AM. & TF & 0,17 & 0,02 & 0,69 & 0,01 & 90,51 & 1,55 & 1,92 & 0,62 & 2,75 & 98 & 0,87 & 68,7 \\
\hline PONTO 045: 0-40 & FOPESTA VPRGE & HT VER & $\mathrm{TF}$ & 0,21 & 0,02 & 0,45 & 0,01 & 81,62 & 2,17 & 8,99 & 0,96 & 3,40 & 98 & 0,67 & 93,0 \\
\hline PONTO 045: 100-120 & FLORESTA VIRGEM & LAT. VER. AM. & $\mathrm{TF}$ & 1,06 & 0,02 & 0,38 & 0,01 & 79,33 & 3,83 & 15,96 & 0,87 & 3,05 & 105 & 1,45 & 91,7 \\
\hline PONTO 112: 0-20 & & & $\mathrm{TF}$ & 0,12 & 0,03 & 1,23 & 0,08 & 86,90 & 1,88 & 6,53 & 1,30 & 2,10 & 100 & 1,43 & 82,1 \\
\hline PONTO 112: 20-35 & FLORESTA DESMATADA - ROÇA DE & & TF & 0,09 & 0,02 & 0,80 & 0,02 & 86,12 & 1,62 & 6,22 & 0,94 & 1,60 & 97 & 0,91 & 87,2 \\
\hline PONTO 112: 35-50 & MANDIOCA & LAT. AM. & $\mathrm{TF}$ & 0,08 & 0,02 & 0,67 & 0,01 & 85,38 & 1,82 & 7,10 & 0,98 & 1,50 & 98 & 0,76 & 90,4 \\
\hline PONTO 112: 50-70: & & & $\mathrm{TF}$ & 0,07 & 0,02 & 0,65 & 0,01 & 90,44 & 2,07 & 8,28 & 1,17 & 1,20 & 104 & 0,73 & 91,9 \\
\hline PONTO 113: 0-20 & & & $\mathrm{TF}$ & 0,22 & 0,03 & 1,07 & 0,01 & 85,48 & 1,85 & 6,37 & 0,25 & 3,45 & 99 & 1,30 & 83,1 \\
\hline PONTO 113: 20-35 & FLORESTA DESMATADA - ROÇA DE & AT AM & $\mathrm{TF}$ & 0,25 & 0,02 & 0,80 & 0,01 & 83,41 & 1,90 & 7,19 & 0,30 & 1,80 & 96 & 1,06 & 87,2 \\
\hline PONTO 113: 35-50 & MILHO & LAT. AM. & TF & 0,17 & 0,02 & 0,67 & 0,01 & 85,59 & 2,28 & 8,56 & 0,29 & 1,85 & 99 & 0,85 & 91,0 \\
\hline PONTO 113: 50-64 & & & $\mathrm{TF}$ & 0,21 & 0,02 & 0,71 & 0,01 & 87,55 & 2,72 & 8,83 & 0,30 & 1,95 & 102 & 0,93 & 90,5 \\
\hline PONTO 114: $0-20$ & & & $\mathrm{TF}$ & 0,18 & 0,01 & 0,17 & 0,01 & 85,89 & 1,89 & 5,56 & 0,33 & 2,60 & 97 & 0,36 & 93,8 \\
\hline PONTO 114: 20-30 & FORESTA YIPGEM & AT AM & TF & 0,15 & 0,03 & 0,12 & 0,01 & 87,25 & 2,10 & 5,94 & 0,29 & 2,30 & 98 & 0,28 & 95,5 \\
\hline PONTO 114: 30-40 & FLORESTA VIRGEM & LAT. AM. & TF & 0,12 & 0,02 & 0,11 & 0,01 & 89,62 & 2,03 & 8,06 & 0,38 & 1,25 & 102 & 0,24 & 97,1 \\
\hline PONTO 114: 40-56 & & & TF & 0,11 & 0,02 & 0,11 & 0,01 & 84,34 & 1,94 & 8,42 & 0,41 & 1,05 & 96 & 0,23 & 97,3 \\
\hline PONTO 062: 0-10 & ZONA DEVARZEA - PASTAGEM & GLEI. HÁP. & Varz. & 0,26 & 0,24 & 1,26 & 0,96 & 71,10 & 5,72 & 12,04 & 1,17 & 7,30 & 100 & 2,48 & 82,9 \\
\hline PONTO 65: 0-15 & FLORESTA DEV VARZEA & $\begin{array}{l}\text { PLINT. } \\
\end{array}$ & Varz. & 0,21 & 0,55 & 0,99 & 2,2 & 60,2 & 8,35 & 23,65 & 1,08 & 5,6 & 103 & 3,40 & 87,4 \\
\hline PONTO 068: 0-20 & ZZNA DE YARZEAYEG BASTERA & GLEL HÁP. & Varz. & 1,14 & 1,07 & 1,08 & 3,73 & 54,1 & 7,83 & 30,09 & 0,92 & 4,85 & 105 & 5,95 & 83,5 \\
\hline PONTO 068: 20-40 & & & Varz. & 1,63 & 0,92 & 1,55 & 2,56 & 49,6 & 6,46 & 36,07 & 1,20 & 4,55 & 105 & 5,75 & 86,3 \\
\hline PONTO 081: 0-30 & Foresta próx. amb. de Várzea & PLINT. & Varz. & 0,12 & 0,05 & 0,62 & 0,11 & 71,4 & 2,31 & 24,02 & 1,32 & 6,05 & 106 & 0,85 & 96,6 \\
\hline PONTO 110: 0-40 & & & Varz. & 0,30 & 0,18 & 1,08 & 1,01 & 70,10 & 5,84 & 15,30 & 1,02 & 6,85 & 102 & 2,39 & 86,5 \\
\hline PONTO 110: 40-70 & ZONA DE VARZEA - PASTAGEM & GLEII. & Varz. & 0,18 & 0,20 & 1,04 & 0,90 & 72,50 & 4,89 & 15,44 & 1,24 & 4,95 & 101 & 2,12 & 87,9 \\
\hline PONTO 110: 70-100 & & & Varz. & 0,17 & 0,18 & 0,88 & 0,87 & 71,50 & 6,21 & 17,23 & 1,42 & 5,30 & 104 & 1,92 & 90,0 \\
\hline PONTO 111: 0-10 & & & Varz. & 0,28 & 0,35 & 1,05 & 1,80 & 63,46 & 5,32 & 14,28 & 1,00 & 6,25 & 94 & 3,13 & 82,0 \\
\hline PONTO 111: 10-20 & ZONA DE VARZEA - PASTAGEM & GLEII. & Varz. & 0,22 & 0,36 & 0,99 & 1,50 & 63,95 & 7,08 & 14,38 & 1,17 & 5,50 & 95 & 2,71 & 84,1 \\
\hline PONTO 111: 20-35 & & & varz. & 0,22 & 0,44 & 1,02 & 1,48 & 64,26 & 2,67 & 15,57 & 1,32 & 3,25 & 90 & 2,72 & 85,1 \\
\hline
\end{tabular}


De forma geral, os solos da região de terra firme são particularmente ricos em sílica (Si) e empobrecidos em macro nutrientes ( $\mathrm{Na}, \mathrm{K}, \mathrm{Ca}, \mathrm{Mg}$ ) (Tabela 6, Figura 23 - C). Este resultado permite auxiliar na classificação de terceiro nível categórico dos solos (distróficos). Esses resultados são compatíveis com a mineralogia desse solos e já eram esperados tendo em vista que os solos da região são derivados dos sedimentos da Formação Alter do Chão (arenitos arcoseanos, pelitos, argilitos, arcóseos, quartzo-arenitos) e passaram por intensos processos de lixiviação.

Por outro lado as amostras coletadas na zona de várzea apresentam composição química diferente das amostras coletadas em terra firme. As amostras da zona de várzea apresentam menor concentração de sílica (óxido de silício - $\mathrm{SiO}_{2}$ ) e maiores concentrações dos outros elementos, especialmente $\mathrm{Al}_{2} \mathrm{O}_{3}, \mathrm{Fe}_{2} \mathrm{O}_{3}, \mathrm{TiO}_{2}$ (Tabela 6, Figura 23). A quantidade de nutrientes e os valores do PF também são maiores nesses solos, conferindo maior fertilidade química aos solos de Várzea quando comparados aos solos da Terra Firme (Figura 24). Os solos de Várzeas são mais novos e "rejuvenescidos" anualmente devido as adições de minerais durante os períodos de enchente da bacia. Essa variação de composição química é associada a composição mineralógica mais diversificada dos solos da zona de várzea (que são constantemente abastecidos pelos sedimentos carreados pelo Rio Amazonas que adentram a área de estudo); a mudança mais notória quando compara-se as análises químicas das amostras das duas zonas é a diminuição das concentrações de $\mathrm{Si}$ e o aumento do Alumínio $\left(\mathrm{Al}_{2} \mathrm{O}_{3}\right)$ (Figura 23 - C). Essas variações estão também associadas à diminuição da quantidade de quartzo nos solos e no aumento de minerais ricos em alumínio (Al) como caulinita (essa variações de valores também podem ser correlacionadas as alteração de granulometria entre as zonas de terra firme e várzea) (Figura 23 e Figura 20). 


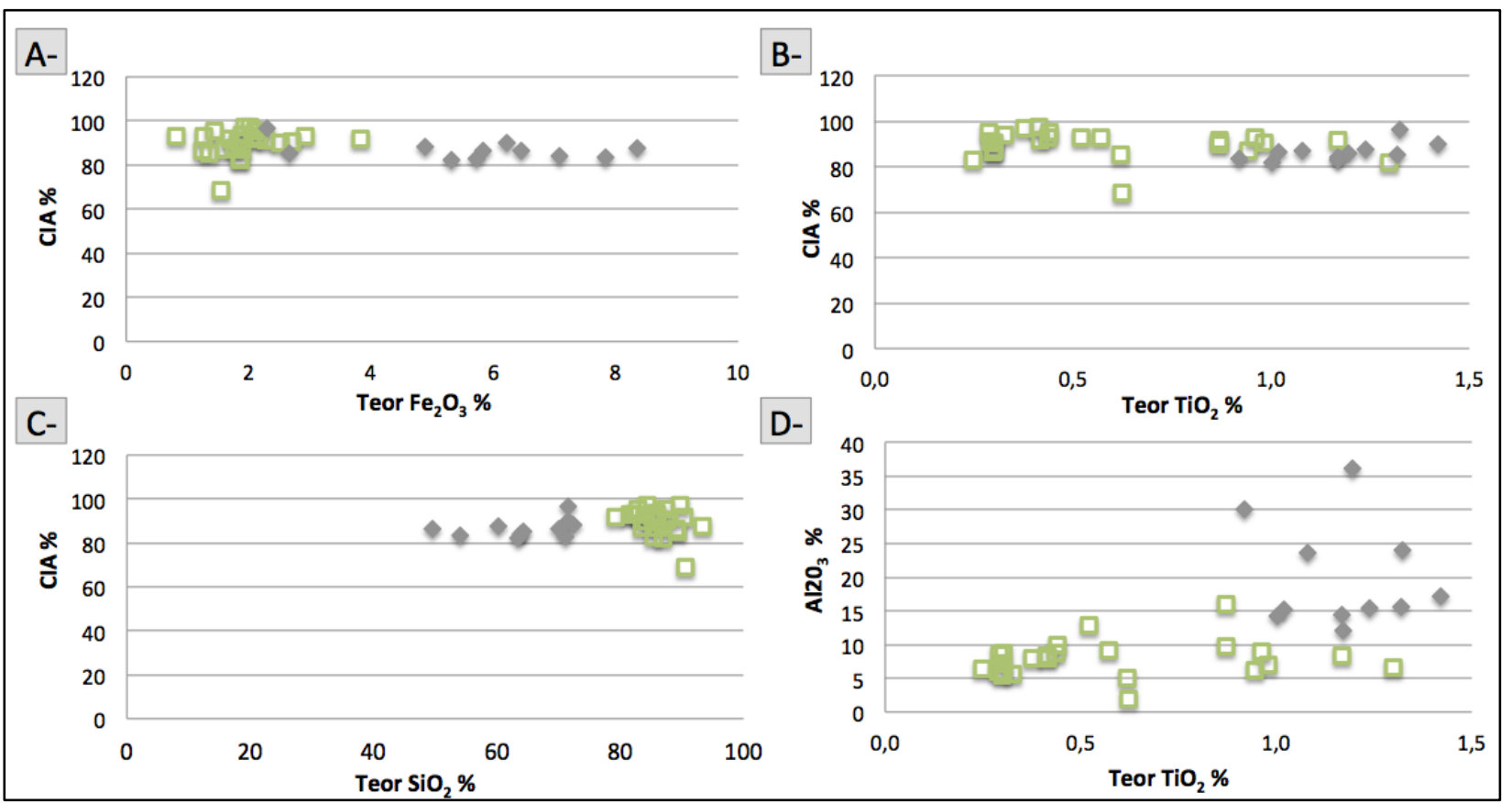

Figura 23- Relação entre A) Teor de $\mathrm{Fe}_{2} \mathrm{O}_{3}$ e CIA (Índice de intemperismo), B) Teor de $\mathrm{TiO}_{2}$ e CIA, C) $\mathrm{Teor}_{\text {de }} \mathrm{SiO}_{2}$ contra CIA, D- entre Teores de $\mathrm{Al}_{2} \mathrm{O}_{3}$ e $\mathrm{TiO}_{2}$; com as solos de Terra firme representados pelos quadrados verdes e os solos da Várzea pelos losangos cinzas.

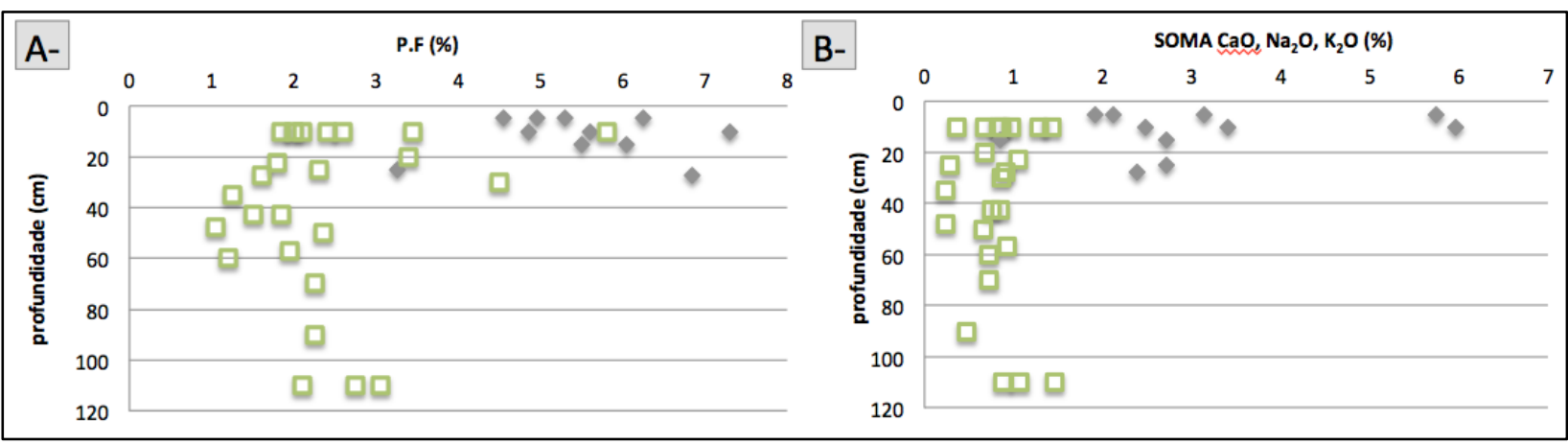

Figura 24 - A- Perda ao fogo em função da profundidade, B- a soma de macronutrientes $\left(\mathrm{CaO}, \mathrm{Na}_{2} \mathrm{O}, \mathrm{K}_{2} \mathrm{O}\right)$ nas amostras de Terra firme (quadrado verde) e as amostras de Várzea (losangos cinza). Os maiores valores de nutrientes e de carbono orgânico (PF) concentram-se nos centímetros superficiais do perfil de solo.

Portanto, analisando-se de forma abrangente a diferença mineralógica e geoquímica em relação à natureza dos materiais de origem desses solos temos que, os solos de várzea incorporam anualmente (por adição) sedimentos novos, particularmente ricos em argila, minerais de tipo 2:1; assim o maior teor de alumínio (bem como os demais resultados químicos e mineralógicos) nos solos de várzea pode ser explicado pelas diferenças de materiais que compõem cada zona: Formação Alter de Chão, do Terciário, compondo a zona de terra firme e fornecendo material para a evolução dos perfis de solo (com minerais fortemente intemperizados/lixiviados) contra aluviões do Quaternário compondo a zona de várzea, e recebendo adição de novos sedimentos anualmente.

A presença, por exemplo, de anatásio (encontrado nas fração total e argila dos solos da zona de várzea e em alguns solos da zona de transição) explica provavelmente quantidade de 
$\mathrm{TiO}_{2}$ nesses solos; da mesma forma, a nontronita identificada em alguns solos de várzea pode explicar em parte a maior quantidade de Ferro nesses solos. Além disso, as alternâncias entre os períodos de alagamento e seca promove a precipitação e cristalização de oxi-hidróxidos de ferro, alumínio e manganês. Os argilominerais do tipo 2:1 são herdadas dos sedimentos que são depositados e, portanto, possuem origem distante da área de estudo (Guyot et al., 2007).

Todos os dados obtidos demonstram e justificam a heterogeneidade observada em um solo de aluvião novo (solos de Várzea) quando comparado aos solos de terra firme.

Da mesma forma, a composição mineralogica dos sedimentos e MES coletados na Várzea durante o Projeto também foram comparados a dos solos de Terra Firma e Várzea. Os sedimentos são geoquimicamente muito semelhantes aos solos da zona de várzea. Podemos ressaltar inclusive os altos teores de $\mathrm{TiO}_{2}, \mathrm{Al}_{2} \mathrm{O}_{3}, \mathrm{Fe}_{2} \mathrm{O}_{3}$ e $\mathrm{PF}$ semelhantes a respostas dadas pelos solos da várzea (Tabela 7).

Tabela 7 - Composição química dos sedimentos coletados na zona de várzea. (Araújo et al., 2014).

\begin{tabular}{|c|c|c|c|c|c|c|c|c|c|c|c|c|}
\hline & profundidade & $\mathrm{CaO}$ & MgO & $\mathrm{Na2O}$ & $\mathrm{K} 2 \mathrm{O}$ & $\mathrm{SiO2}$ & Al2O3 & $\mathrm{Fe} 2 \mathrm{O3}$ & Mn2O & TiO2 & $\mathbf{P F}$ & TOTAL \\
\hline & $\mathrm{cm}$ & \multicolumn{10}{|c|}{ em \% } & \\
\hline FAB V-24 Core C1 & $0-1$ & 0,90 & 0,75 & 2,04 & 2,39 & 56,5 & 17,17 & 6,76 & 0,18 & 0,87 & 12,7 & 100,18 \\
\hline FAB V-24 Core C2 & $1-2$ & 0,93 & 0,75 & 1,09 & 2,29 & 60,3 & 15,78 & 6,47 & 0,19 & 0,87 & 11,5 & 100,19 \\
\hline FAB V-24 Core C3 & $2-5$ & 1,19 & 0,75 & 1,06 & 2,31 & 54,3 & 16,07 & 6,84 & 0,19 & 0,84 & 16,6 & 100,19 \\
\hline FAB V-24 Core C4 & $5-9$ & 1,00 & 0,77 & 0,90 & 2,32 & 57,6 & 16,59 & 6,93 & 0,16 & 0,84 & 13,0 & 100,16 \\
\hline FAB V-24 Core C5 & $9-11$ & 1,32 & 0,77 & 1,55 & 2,24 & 57,0 & 17,26 & 7,14 & 0,18 & 0,84 & 11,8 & 100,18 \\
\hline FAB V-24 Core C6 & $11-13$ & 0,94 & 0,76 & 1,59 & 2,27 & 57,8 & 17,66 & 6,71 & 0,13 & 0,86 & 11,4 & 100,13 \\
\hline FAB V-24 Core C7-1 & $13-14$ & 0,81 & 0,77 & 0,81 & 2,27 & 58,3 & 17,04 & 6,92 & 0,14 & 0,86 & 12,2 & 100,14 \\
\hline FAB V-24 Core C7-2 & $14-15$ & 0,85 & 0,80 & 0,86 & 2,44 & 56,9 & 17,68 & 7,32 & 0,14 & 0,85 & 12,3 & 100,14 \\
\hline FAB V-24 Core C7-3 & $15-16$ & 0,94 & 0,79 & 2,18 & 2,38 & 54,4 & 18,95 & 7,27 & 0,13 & 0,86 & 12,2 & 100,13 \\
\hline FAB V-24 Core C8 & $16-18,5$ & 0,81 & 0,76 & 1,56 & 2,43 & 54,9 & 18,41 & 7,47 & 0,12 & 0,86 & 12,8 & 100,12 \\
\hline FAB V-24 Core C9 & $18,5-21$ & 0,81 & 0,72 & 0,77 & 2,24 & 57,3 & 16,72 & 7,48 & 0,12 & 0,80 & 13,1 & 100,12 \\
\hline FAB V-24 Core C10 & $21-26$ & 0,88 & 0,74 & 0,88 & 2,30 & 56,5 & 17,07 & 7,77 & 0,11 & 0,81 & 13,0 & 100,11 \\
\hline FAB-II-21a & $0-1$ & 1,17 & 0,81 & 2,03 & 2,55 & 63,5 & 20,02 & 8,91 & 0,18 & 1,01 & 10,8 & 110,98 \\
\hline FAB-II-21b & $01 /$ fev & 1,23 & 0,92 & 1,09 & 2,45 & 59,5 & 23,69 & 9,98 & 0,18 & 1,14 & 11,1 & 111,28 \\
\hline FAB-II-21c & 05/out & 1,18 & 0,90 & 1,99 & 2,70 & 58,3 & 23,87 & 9,74 & 0,15 & 1,26 & 9,5 & 109,65 \\
\hline FAB-II-32a & $0-2$ & 1,01 & 0,82 & 1,78 & 2,34 & 43,9 & 26,94 & 10,43 & 0,10 & 1,22 & 11,5 & 100,10 \\
\hline FAB-II-32b & $02 / \mathrm{mai}$ & 1,25 & 0,93 & 0,72 & 2,55 & 46,5 & 28,80 & 11,43 & 0,12 & 1,39 & 6,4 & 100,12 \\
\hline FAB-II-32c & $40-50$ & 0,73 & 0,60 & 0,50 & 1,81 & 61,8 & 21,33 & 11,09 & 0,06 & 0,96 & 1,1 & 100,06 \\
\hline
\end{tabular}

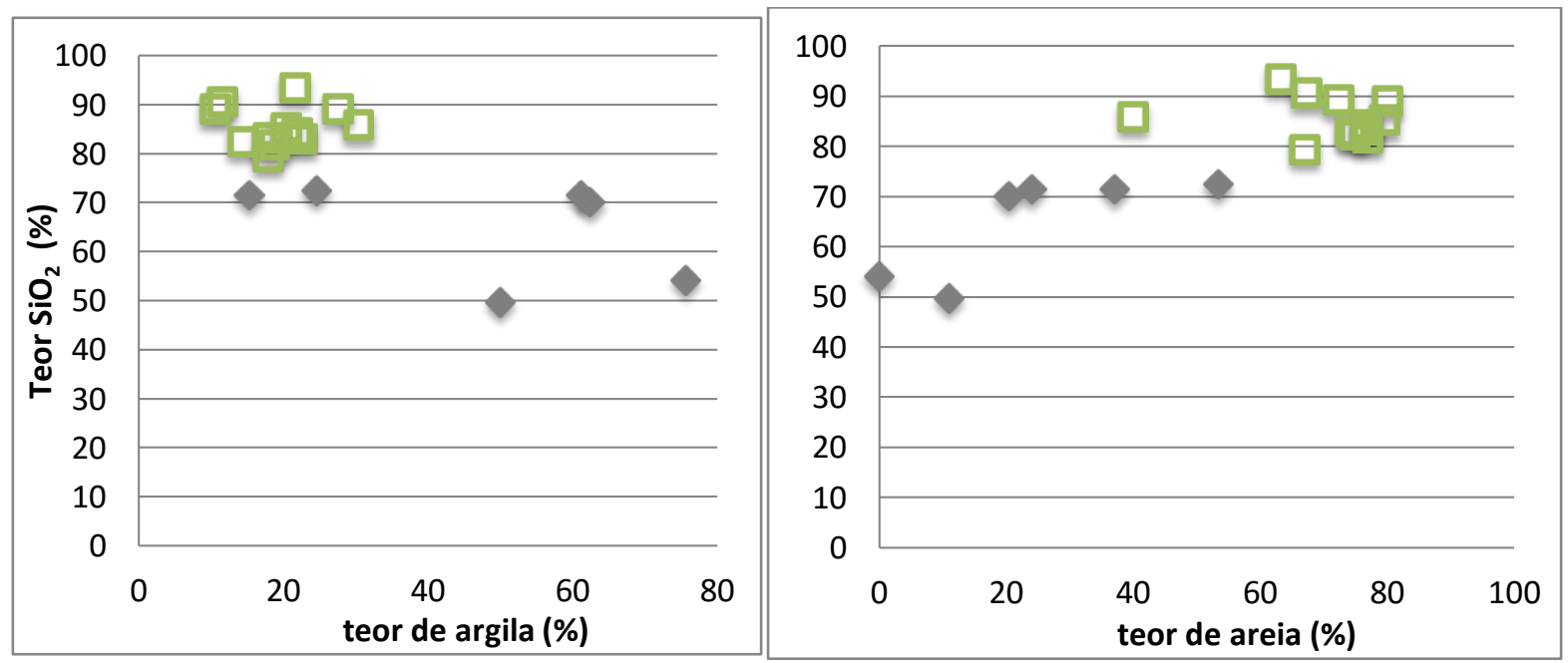

Figura 25 - Relação entre o teor de $\mathrm{SiO} 2$ e a quantidade (\%) de argila ou areia dos solos de Terra firme (quadrado verde) e da Várzea (losango cinza). 
Baseado nas relações entre os teores de $\mathrm{SiO}_{2}$ e quantidade de areia e argila pode-se notar, (Figura 25) a relação entre a composição químicas dos solos, a pedogênese (matriz - material fonte) e funcionamento dos solos (adições de sedimento): os solos de terra firme apresentam maiores teores de $\mathrm{SiO} 2$ e maior granulometria enquanto que os solos de várzea apresentam menores teores de argila e menores teores de sílica.

O carbono orgânico total (COT) foi estimado a partir dos valores de perda ao fogo (Tabela 6 e Figura 26).

Foram analisados solos associados a diversas coberturas vegetais (floresta nativa, floresta secundária, plantio de roça, pasto, áreas desmatadas) e diferentes relevos e observou-se que a concentração de COT presente nos solo diminui à medida que a profundidade do solo aumenta (com exceção do ponto 006 que apresenta um leve acréscimo na quantidade de COT na transição entre o primeiro e o segundo horizonte (Figura 26). Esta tendência foi correlacionada principalmente a diminuição da atividade biológica ao longo do perfil (Gonçalves et al., 2007).

Em análise mais detalhada, considerando primeiramente apenas os solos da zona de terra firme, é possível observar é a discrepância entre a quantidade de COT no horizonte superficial de um solo sob uma área de floresta (ponto 38, por exemplo) e a quantidade de COT no horizonte superficial dos solos das demais áreas (ponto 005, por exemplo - solo de área de pasto). A elevada concentração de COT nos solos das áreas de floresta nativa, quando comparada aos solos das outras vegetações, está relacionada a um horizonte $\mathrm{O}$ mais espesso (normalmente superior a $30 \mathrm{~cm}$ ) com forte atividade biológica. Nas outras áreas a vegetação nativa já foi retirada (está se recuperando - florestas desmatadas, vegetação secundária - ou foi totalmente substituída normalmente por pastos ou roças) e o horizonte $\mathrm{O}$ é muito delgado, por vezes inexistente. As interpretações acima já vinham sendo feitas por diversos pesquisadores (Lopes, 1983; Malavolta; Kliemann, 1985; Sanchez, 1976; Vieira e Santos, 1987), por exemplo, Lucas et al. 1993 que relaciona altas taxas de carbono orgânico nos primeiros centímetros de solo a reciclagem de materiais provenientes da floresta. 


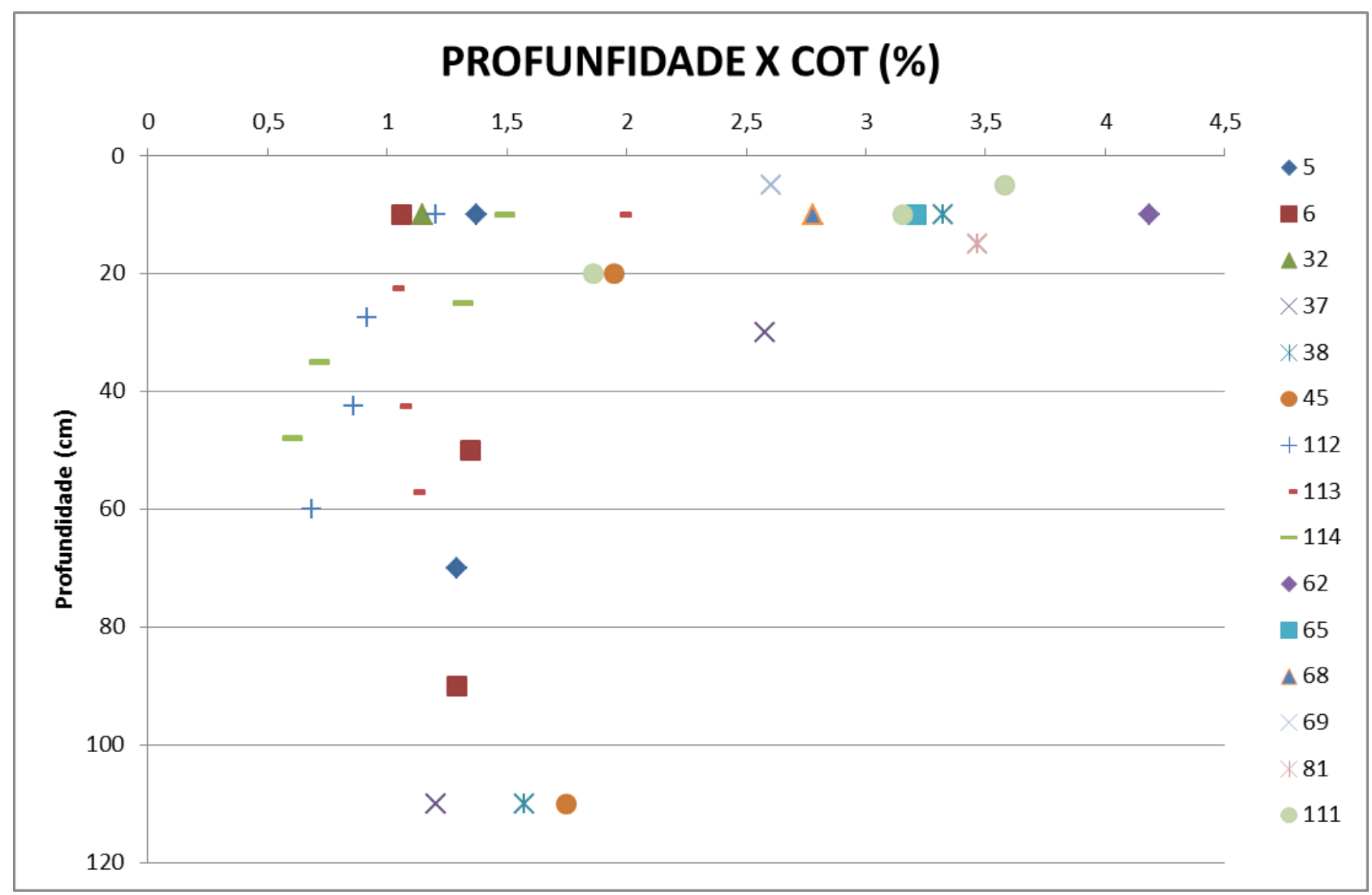

Figura 26- Teor em Carbono orgânico total em função da profundidade de uma seleção de solos da bacia (amostras de terra firme: 5, 6, 32, 37, 38, 45, 112, 113, 114; amostras de várzea: 62, 65, 68, 69, 81, 111).

A análise dos solos da zona de várzea revela que os solos dessa área possuem, frequentemente, maiores quantidades de COT. Isto está relacionado a grande quantidade de matéria orgânica particulada ou dissolvida transportada pelas águas do lago que acabam se depositando nessa zona (Tabela 6 e Tabela 7). Além disso, o processo de hidromorfia e o desaparecimento progressivo do oxigênio também podem ser a causa de um abrandamento da decomposição da matéria orgânica que se acumula.

\section{4 - Mapa Pedológico}

O mapa pedológico da área de estudo elaborado pela EMBRAPA é apresentado abaixo (Figura 27). Em amarelo, é possível observar o que foi designado como sendo um latossolo amarelo distrófico representando toda a área de terra firme e em cinza temos o que é designado como um gleissolo háplico, o qual pode variar entre eutrófico e distrófico. É importante ressaltar que para elaboração desse mapa a EMBRAPA utilizou dados pedológico coletados em diversas partes do Estado do Pará, mas não há pontos pedológicos diretamente inseridos na área de estudo (o levantamento bibliográfico realizado revelou que os pontos de descrição pedológica utilizados pela EMBRAPA encontram-se a mais de $60 \mathrm{~km}$ do limite com a área de estudo http://www.bdsolos.cnptia.embrapa.br/esclarecimentos_uso). 


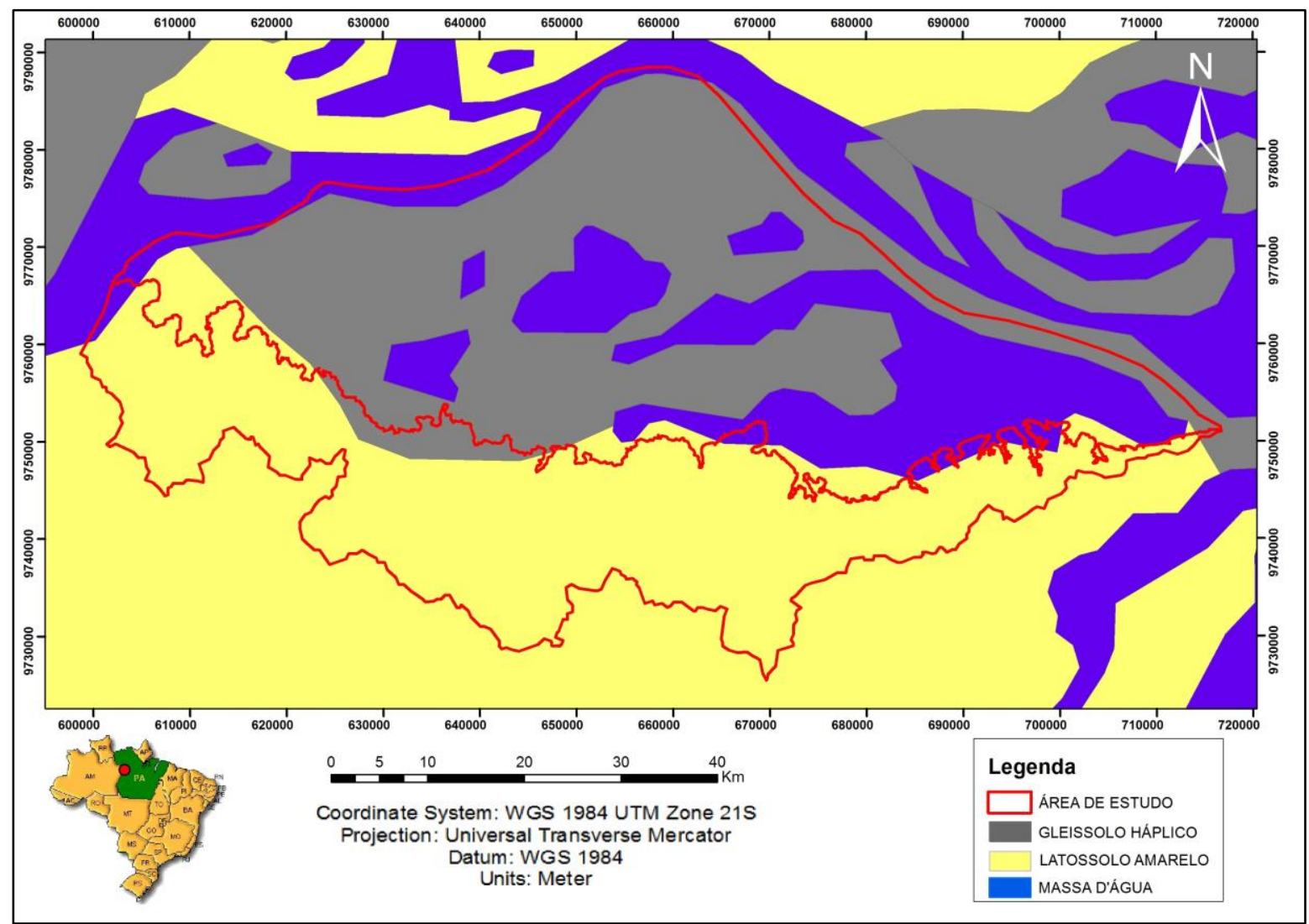

Figura 27 - Mapa pedológico da EMBRAPA retratando a área de Estudo.

Com base em dados levantados em campo, em laboratório e nas pesquisas bibliográficas foi possível elaborar um mapa pedológico da área de estudo.

A fim de se elaborar um mapa pedológico coerente e consistente com o observado em campo, além dos mais de 100 pontos pedológicos descritos, foram utilizadas ferramentas de interpolação de dados do Arcgis, shapes de vegetação, relevo, hidrografia, geologia e solos disponibilizados pela EMBRAPA, INPE, IBGE e CPRM, bem como toda a base de dados blibliográficos. Todas essas ferramentas utilizadas foram de grande valia pra inferir e/ou estimar os tipos de solo nas zonas em que o acesso físico não foi possível.

O mapa pedológico final da Bacia de Curuai apresentado na Figura 28 manteve o resultado esperado, onde se observa um predomínio de um latossolo amarelo na porção de terra firme e de um gleissolo háplico na zona de várzea. Podemos constatar que este novo mapa é semelhante ao mapa elaborado pela EMBRAPA. 


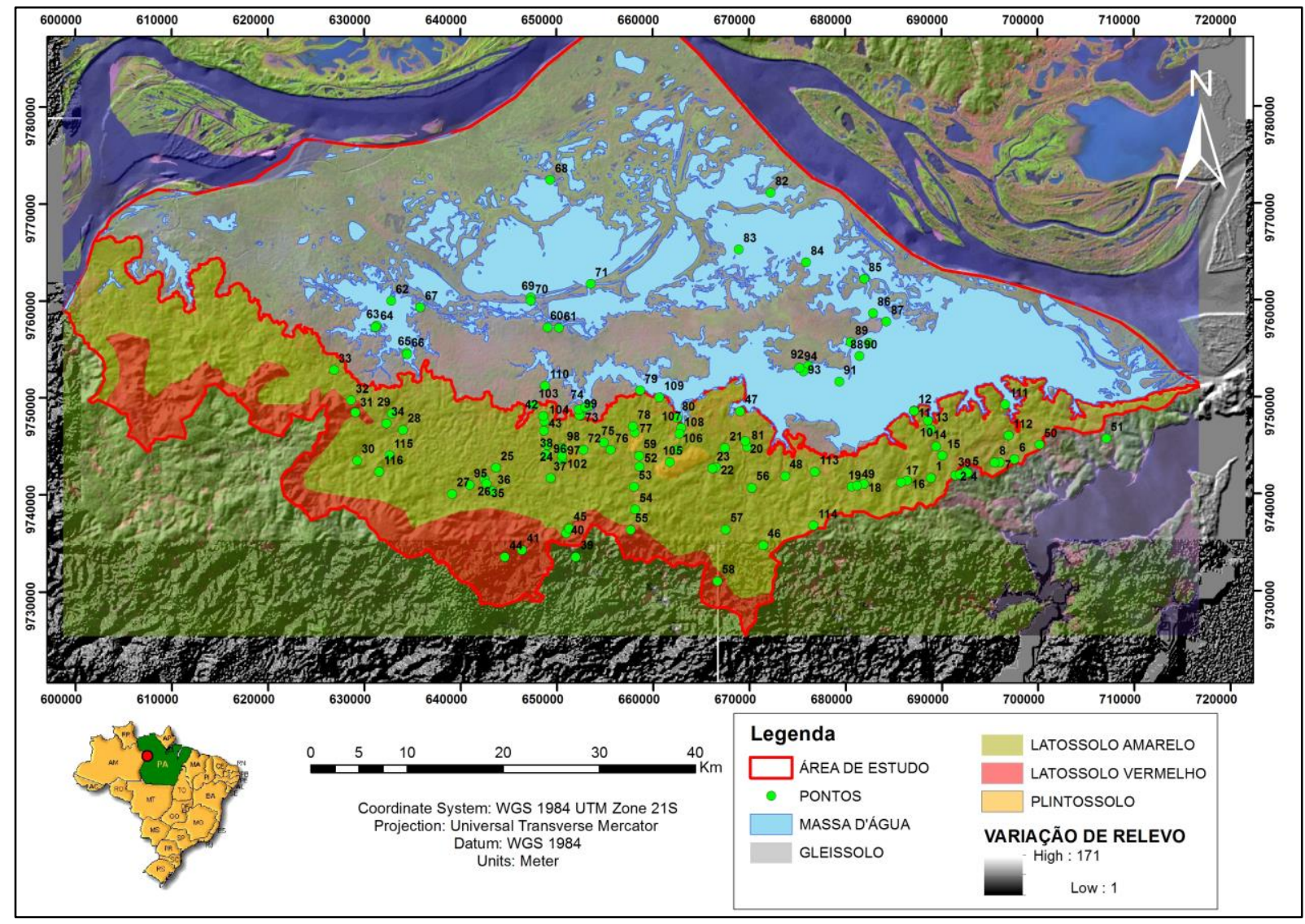

Figura 28 - Mapa pedológico da área de estudo. Apresentação de todos os pontos de análise pedológica sobrepostos ao modelo digital de terreno e à imagem de satélite da bacia adquirida no período da seca (outubro/2011).

O latossolo amarelo ocupa aproximadamente 78,5\% da zona de terra firme (113.802 ha) e está relacionado a um relevo plano a suave ondulado (Figura 28).De forma geral, o latossolo amarelo apresenta coloração bege clara a amarelado (7,5YR A 10YR), trata-se de um solo permeável e bem drenado sendo utilizado principalmente para pastagem. Ocorre em todos os tipos de vegetação presentes na terra firme (floresta nativa, floresta secundária, floresta em regeneração, roça, pasto) não sendo possível correlacionar sua ocorrência com algum tipo de vegetação.

Quando relacionado a uma vegetação de floresta nativa, após o desmatamento da área muitas vezes é empregado o cultivo de mandioca (roça) de modo a aproveitar os nutrientes presentes no horizonte $\mathrm{O}$ e depois de um tempo (no máximo cinco anos de utilização segundo relatos) é implementado o pasto na área desmatada se for do interesse do proprietário (durante essa transição observa-se uma forte diminuição do horizonte). Até mesmo o pasto tem "prazo de validade", pois devido a escassez de nutrientes no solo, aos problemas de compactação por parte dos animais nele alocados (gado, búfalos e cavalos) e pela falta de técnicas para a manutenção do solo o cultivo de pasto também não persiste por mais do que cinco anos, conforme relato nos moradores da região. 
Em seu terceiro nível categórico os latossolos podem ser classificados como distróficos por se tratarem de solos de baixa fertilidade natural. Já no quarto nível categórico podem ser classificados como típicos ou húmicos quando a camada superficial apresenta elevada concentração de matéria orgânica.

O latossolo amarelo típico da área apresenta as seguintes características:

- Horizonte O: A ocorrência do horizonte $\mathrm{O}$ esta diretamente relacionada as áreas com vegetação densa, floresta. Em áreas de floresta nativa é possível observar um horizonte $\mathrm{O}$ superior a 30 centímetros $(\mathrm{cm})$ mas nas porções que sofreram desmatamento (para o implemento de pastos, roças, construção de moradias) o horizonte $\mathrm{O}$ pode ser menor que $5 \mathrm{~cm}$ e muitas vezes é praticamente inexistente.

- Horizonte A: O horizonte A varia de proeminente a moderado, possui coloração escura (bruno escuro), textura média a arenosa, grãos subangulares, estrutura comum pequena granular, consistências seca, úmida e molhada: solto, friável e não pegajoso (respectivamente), ligeiramente plástico e com transição gradual. A principal mineralogia observada nesse horizonte é: quartzo e caulinita, havendo um predomínio de quartzo na fração total e de caulinita na fração argila.

- Horizonte AB e BA: São horizontes de transição, nem sempre existentes e dificilmente diferenciáveis. Apresentam as principais características do horizonte A, porém com uma coloração menos intensa (bruno), que vai adquirindo tons mais claros com a profundidade. Todas as outras características, inclusive a mineralogia são na maioria das vezes coincidentes.

- Horizonte B: O horizonte B é o horizonte diagnóstico, característico, trata-se de um B latossólico típico $(\mathrm{Bw})$ com coloração bruno claro a amarelo, homogêneo, com espessura superior a $100 \mathrm{~cm}$, textura média, estrutura comum, pequena, média grumosa. A mineralogia dificilmente se altera ao longo e entre os perfis de latossolo, havendo sempre um predomínio de quartzo na fração total e de caulinita na fração argila.

Devido ao processo de formação dos solos da área (provável espessa/profunda cobertura pedológica nessa área) e o critério utilizado para classificação dos solos (a classificação brasileira dos solos só se atenta até os dois primeiros metros do perfil de solo) o horizonte C não foi observado em nenhum dos pontos descritos.

O latossolo vermelho ocupa aproximadamente $19,5 \%$ da área de estudo e ocorre principalmente nas áreas de chapada ao sul da área. O principal relevo associado a esse tipo de ocorrência pedológica é o relevo ondulado (Figura 28). Como as porções da área onde foi observado a sua ocorrência sofrem pouca influência antrópica este solo constantemente está associado a vegetações de floresta nativa. Por retratarem solos profundos, permeáveis e bem 
drenados poderiam ser utilizados em práticas agrícolas mas como mencionado a área sobre pouca ou nenhum influência humana. Em seu terceiro nível categórico esse solo é classificado como Distrófico e em um quarto nível com Típico.

O latossolo vermelho apresenta a maioria das características físicas do latossolo amarelo, sendo que o principal critério utilizado na diferenciação entre eles foi a cor (10R a 2,5YR) do horizonte característico ( $\mathrm{Bw}$ - vermelho) e o relevo associado (áreas de chapada, relevo ondulado).

O plintossolo nas áreas de terra firme é marcado por apresentar um relevo intermediário entre o do latossolo amarelo e o latossolo vermelho (Figura 28). Ocupando apenas $1 \%$ da área são observados mais frequentemente nas encostas de pequenos morros sem vegetação característica associada. Em todos os pontos em que foi observado a grande parte vegetação ao redor tinha sido desmata e o material estava sendo usado para manutenção das estradas de terra da região.

Manchas de argissolo, cambissolo, neossolo e latossolo vermelho-amarelo também foram observadas (ocupando cerca de $1 \%$ da área) mas devido a escala de representação do mapa, 1 : 450000, não foram discriminadas. As manchas de argissolo ocorrem principalmente próximo as áreas de várzea, na transição terra firme-zona alagada. Os cambissolos e neossolos foram observados na porção mais ao sudeste da área, próximo a desembocadura do Lago Grande de Curuai; e os latossolos vermelho-amarelo foram observados na zona de transição, contato, entre o latossolo amarelo e o latossolo vermelho.

O gleissolo representa em mapa toda a porção norte da área e pode-se dizer tem sua ocorrência restrita a zona de várzea (zona anualmente alagada) (Figura 28). Tratam-se de solos mais novos, ricos em argila, hidromórficos com horizonte superficial rico em matéria orgânica, coloração escura e apresentando mosqueado em alguns níveis mais profundos (testemunho das alternâncias de condições de óxido-redução). Esses solos podem receber materiais novos (sedimentos) por adição durante os períodos de enchente da bacia. Logo após o horizonte glei é comum a presença de plintita ou até mesmo de horizontes plintíticos. Nos períodos da seca as zonas com gleissolo que são expostas a atmosfera são utilizadas pelos moradores da região para o cultivo de pasto e a alimentação do gado. Em seu segundo nível categórico os gleissolos podem ser classificados como háplicos.

\section{5 - Ensaios de Infiltração}

Devido ao grande tempo requerido para a aplicação de cada técnica e as condições já descritas anteriormente (condições da área de estudo, de transporte) esse procedimento foi realizado de forma bem sucedida em apenas 13 pontos da área de estudo, em seis pontos durante 
a primeira campanha de campo (pontos: 037, 038, 042, 043, 044 e 045 - análises realizadas durante o período de cheia da Bacia) e em mais sete pontos durante a segunda campanha de campo (pontos: 095, 098, 100, 104, 107, 109 e 110 - análises realizadas durante o período de seca da Bacia).

Os pontos para as análises foram escolhidos com base no tipo de solo, na vegetação e no relevo associados (porém as variações de relevo eram pouco notórias em campo). Com base nisso foi delimitado um transecto base, cortando quase que perpendicularmente a orientação dos principais limites pedológicos para a orientação dos pontos. $\mathrm{O}$ transecto inicia no sul da bacia de Curuai, local de maior elevação e vegetação mais preservada, em direção ao centro da várzea, com relevo aplainado e vegetação impactada pela população local (Figura 29,Figura 30 e Tabela 8).

Os valores de infiltração estão relacionados a vários parâmetros físicos do solo (textura, presença de matéria orgânica, nível de compactação do solo, nível de saturação do solo quanto a quantidade de água - umidade do solo) e estão de acordo com os dados apresentados em trabalhos como Oliveira et al., (2011) e Riquelme et al., (2012) (Tabela 9).

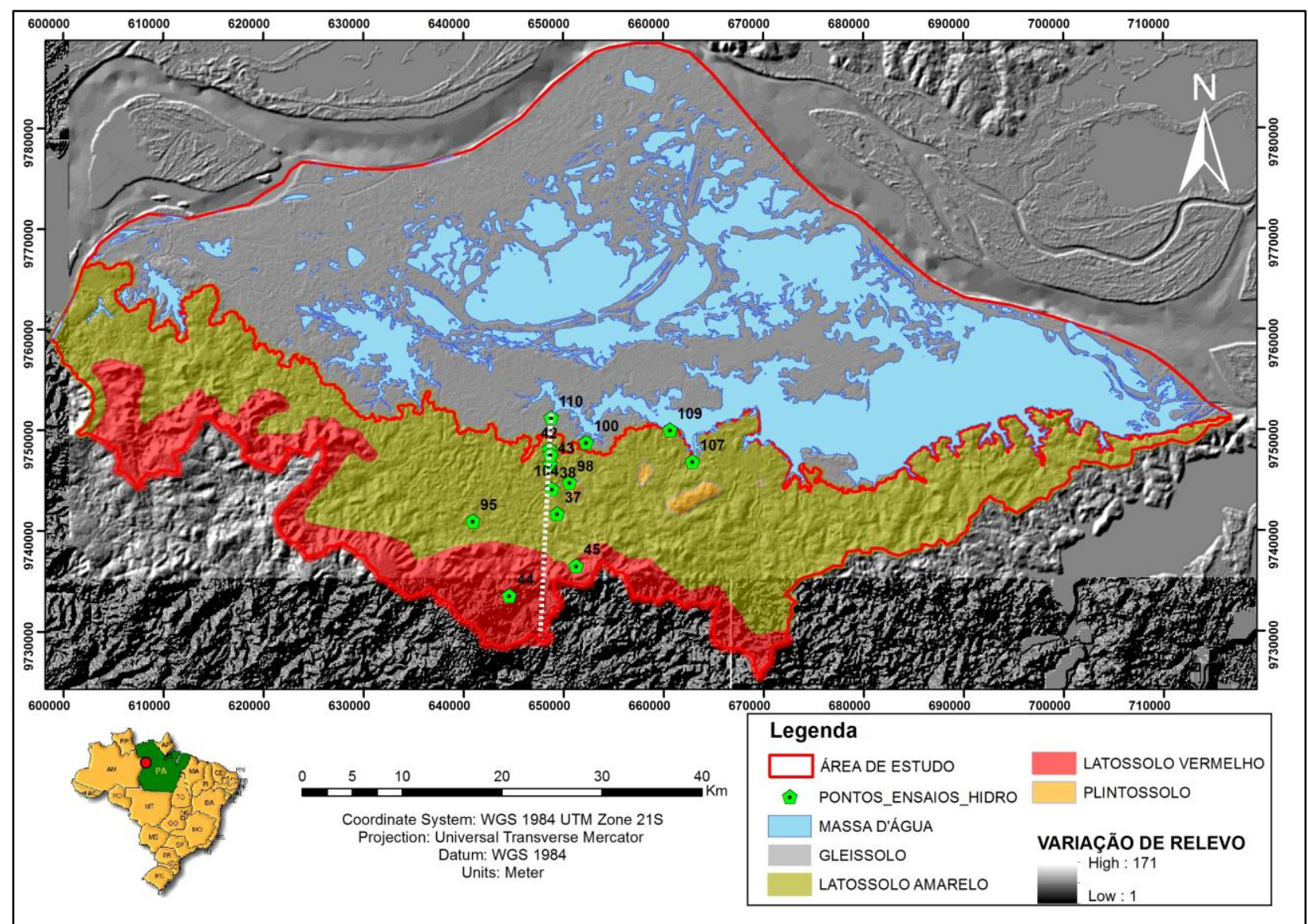

Figura 29 - Distribuição espacial dos pontos analisados apresentados sobre um mapa integrado de relevo e pedologia. A linha branca pontilhada representa o transecto base utilizado como guia para a realização dos ensaios de infiltração. 


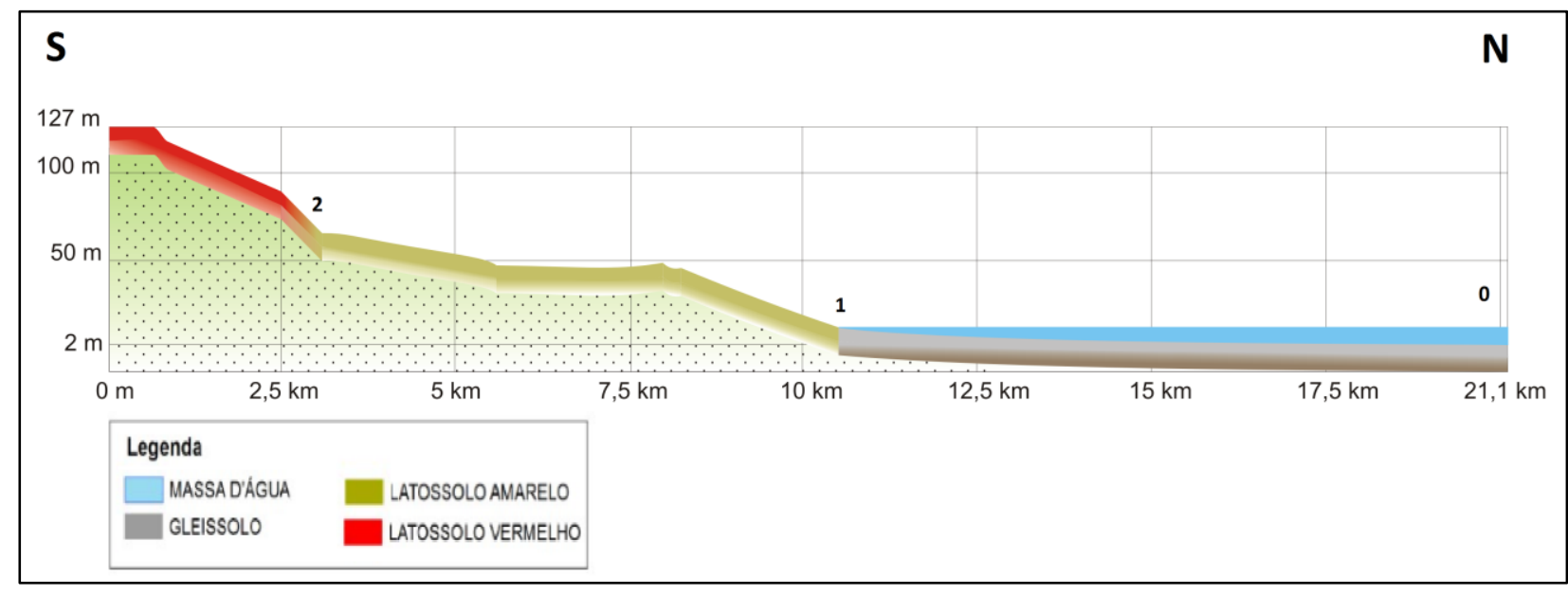

Figura 30 - Representação esquemática do relevo da porção seccionada pelo transecto base. (Essa representação foi feita com o auxílio da ferramenta "perfil de elevação" do software Google Earth). Analisando o transecto de norte a sul temos: de 0 a 1 a porção que fica dentro dos limites da zona de várzea; a partir de 1, no sentido Sul, temos o relevo da zona de terra firme. $O$ espaço de 0 a 1 esta sob um gleissolo háplico, de 1 a 2, tem-se a predominância do latossolo amarelo e a partir de 2 (sentido sul) tem-se a predominância do latossolo vermelho.

Tabela 8 - Breve descrição quanto a vegetação e o tipo de solo do local de análise.

\begin{tabular}{|c|c|c|c|c|}
\hline PONTO & COORD X & COORD Y & SOLO & LOCAL DE ANÁLISE \\
\hline 37 & 649355 & 9741678 & LATOSSOLO AMARELO & $\begin{array}{c}\text { AMBIENTE DE PASTO SUJO COM VEGETAÇÃO ESPAÇADA } \\
\text { DE PEQUENO E BAIXO PORTE. TRATA-SE DE UMA ZONA } \\
\text { DE FLORESTA QUE FOI DESMATADA PARA POSTERIOR } \\
\text { IMPLANTAÇÃO DE PASTO }\end{array}$ \\
\hline 38 & 648836 & 9744108 & LATOSSOLO AMARELO & $\begin{array}{c}\text { ZONA DE AGROFLORESTA COM PLANTAÇÃO DE ESPECIES } \\
\text { NATIVAS (CUPUAÇU, AÇAI, MURICI) E NÃO NATIVA } \\
\text { (CAFÉ, COCO, ABACATE) }\end{array}$ \\
\hline 42 & 648594 & 9748076 & LATOSSOLO AMARELO & AMBIENTE DE FLORESTA PRÓXIMO A UMA MATA CILIAR \\
\hline 43 & 648657 & 9746582 & LATOSSOLO AMARELO & $\begin{array}{c}\text { TESTE EM ROÇADO, PLANTAÇÃO DE ABACAXI, CUPUAÇU } \\
\text { E AÇAI; PRÓXIMO A UMA MATA CILIAR }\end{array}$ \\
\hline 44 & 644582 & 9733531 & LATOSSOLO VERMELHO-AMARELO & FLORESTA NATIVA \\
\hline 45 & 651256 & 9736489 & LATOSSOLO VERMELHO-AMARELO & FLORESTA NATIVA \\
\hline 95 & 640919 & 9740964 & LATOSSOLO AMARELO & $\begin{array}{l}\text { ZONA DE CULTIVO DE MANDIOCA (ROÇA). TRATA-SE DE } \\
\text { UMA ZONA DE FLORESTA QUE FOI DESMATADA PARA A } \\
\text { IMPLANTAÇÃO DE ROÇA }\end{array}$ \\
\hline 98 & 650594 & 9744776 & LATOSSOLO AMARELO & FLORESTA NATIVA \\
\hline 100 & 652275 & 9748742 & LATOSSOLO AMARELO & PASTO NATURAL NA ZONA DE VÁRZEA \\
\hline 104 & 648699 & 9747552 & LATOSSOLO AMARELO & $\begin{array}{c}\text { ZONA DE CULTIVO DE PASTO. TRATA-SE DE UMA ZONA } \\
\text { DE FLORESTA QUE FOI DESMATADA PARA A } \\
\text { IMPLANTAÇÃO DE PASTO }\end{array}$ \\
\hline 107 & 662908 & 9746842 & GLEISSOLO & AMBIENTE DE FLORESTA DE VÁRZEA \\
\hline 109 & 660641 & 9749996 & LATOSSOLO AMARELO & ÁREA DE PASTO PRÓXIMO A ZONA DE VÁRZEA \\
\hline 110 & 648794 & 9751211 & GLEISSOLO & PASTO NATURAL NA ZONA DE VÁRZEA \\
\hline
\end{tabular}


Tabela 9 - Resultados dos valores de Condutividade Hidraulica (Kv) dos pontos analisados (ver tabela 8 para dados complementares). Devido a proximidade a massas de água o ponto 43 apresentou valores de Kv muito próximos a 0 em 50 e $100 \mathrm{~cm}$ de profundidade e em $150 \mathrm{~cm}$ de profundidade foi atingindo a lamina d'água.

\begin{tabular}{|r|c|c|c|c|c|c|}
\hline PONTO & $\mathbf{3 7}$ & $\mathbf{3 8}$ & $\mathbf{4 2}$ & $\mathbf{4 3}$ & $\mathbf{4 4}$ & $\mathbf{4 5}$ \\
\hline Prof $(\mathrm{cm})$ & $\mathbf{K v}(\mathrm{m} / \mathrm{s})$ & $\mathrm{Kv}(\mathrm{m} / \mathrm{s})$ & $\mathbf{K v}(\mathrm{m} / \mathrm{s})$ & $\mathbf{K v}(\mathrm{m} / \mathrm{s})$ & $\mathrm{Kv}(\mathrm{m} / \mathrm{s})$ & $\mathbf{K v}(\mathrm{m} / \mathrm{s})$ \\
\hline 0 & $1,34^{*} 10^{\wedge}-05$ & $2,52^{*} 10^{\wedge}-06$ & $2,75^{*} 10^{\wedge}-06$ & $4,25^{*} 10^{\wedge}-06$ & $1,31^{*} 10^{\wedge}-06$ & $8,52^{*} 10^{\wedge}-06$ \\
\hline 50 & $4,56^{*} 10^{\wedge}-06$ & $3,03^{*} 10^{\wedge}-06$ & $1,01^{*} 10^{\wedge}-07$ & 0 & $3,24^{*} 10^{\wedge}-06$ & $9,86^{*} 10^{\wedge}-06$ \\
\hline 100 & $7,26^{*} 10^{\wedge}-07$ & $3,16^{*} 10^{\wedge}-07$ & $1,13^{*} 10^{\wedge}-07$ & 0 & $3,04^{*} 10^{\wedge}-07$ & $4,19^{*} 10^{\wedge}-07$ \\
\hline 150 & $3,08^{*} 10^{\wedge}-08$ & $2,04 * 10^{\wedge}-06$ & $4,05^{*} 10^{\wedge}-08$ & ÁGUA & $2,51^{*} 10^{\wedge}-07$ & $6,87^{*} 10^{\wedge}-07$ \\
\hline
\end{tabular}

\begin{tabular}{|r|c|c|c|c|c|c|c|}
\hline PONTO & 95 & 98 & 100 & 104 & 107 & 109 & 110 \\
\hline Prof $(\mathrm{cm})$ & $\mathrm{Kv}(\mathrm{m} / \mathrm{s})$ & $\mathrm{Kv}(\mathrm{m} / \mathrm{s})$ & $\mathrm{Kv}(\mathrm{m} / \mathrm{s})$ & $\mathrm{Kv}(\mathrm{m} / \mathrm{s})$ & $\mathrm{Kv}(\mathrm{m} / \mathrm{s})$ & $\mathrm{Kv}(\mathrm{m} / \mathrm{s})$ & $\mathrm{Kv}(\mathrm{m} / \mathrm{s})$ \\
\hline 0 & $5,5^{*} 10^{\wedge}-04$ & $6,4^{*} 10^{\wedge}-04$ & $1,54^{*} 10^{\wedge}-05$ & $8,66^{*} 10^{\wedge}-06$ & $4,99^{*} 10^{\wedge}-05$ & $4,73^{*} 10^{\wedge}-07$ & $2,36^{*} 10^{\wedge}-06$ \\
\hline $\mathbf{5 0}$ & $1,42^{*} 10^{\wedge}-06$ & $3,29^{*} 10^{\wedge}-05$ & $2,97^{*} 10^{\wedge}-07$ & $9,08^{*} 10^{\wedge}-06$ & $8,20^{*} 10^{\wedge}-06$ & $1,27^{*} 10^{\wedge}-07$ & $3,64^{*} 10^{\wedge}-09$ \\
\hline 100 & $2,16^{*} 10^{\wedge}-06$ & $3,33^{*} 10^{\wedge}-05$ & $2,37^{*} 10^{\wedge}-06$ & $3,98^{*} 10^{\wedge}-06$ & ÁGUA & $2,09^{*} 10^{\wedge}-07$ & $3,59^{*} 10^{\wedge}-09$ \\
\hline
\end{tabular}

Os ensaios de infiltração dos pontos 37 a 45 foram realizados no final do perído de chuvas na região, enquanto que os dos pontos 95 a 110 foram realizados no final do período de seca da região. Essa diferença dos períodos de análise revela variações no comportamento do solo quanto a capacidade de infiltração ao longo do perfil; a principal diferença observada é que durante o período de seca a camada superficial do solo apresenta maior taxa de condutividade hidráulica, provavelmente devido ao nível de umidade no solo que é menor durante a seca. Os valores de $\mathrm{Kv}$ dos solos diminuem com o aumento de profundidade, mostrando maior capacidade de infiltração nos horizontes superficiais.

Um dos objetivos do Projeto é avaliar possíveis alterações nos atributos do solos, especialmente em relação ao ciclo hidrológico, associados as mudanças climáticas e antrópicas. O número de ensaios não foi suficiente para montar um modelo conceitual mas foram observadas alguns variações significativas da condutividade hidráulica $(\mathrm{Kv})$ na camada superficial do solo de acordo com utilização empregada a esse solo.

$\mathrm{Na}$ época da cheia da bacia (período chuvoso), por exemplo, quando comparamos o ponto 37 (ponto referente a uma área de pasto) com os demais pontos (38-área de floresta com leve interferência antrópica, 42, 44 e 45 - floresta nativa), observamos que o horizonte superficial do ponto 37 apresenta maior Kv do que o horizonte superficial dos demais pontos. Este dado pode ser interpretado como resultado de interferência antrópica nessa área. Essas áreas normalmente tem sua vegetação nativa retirada por processos de queimadas. Essa prática cultural diminui a umidade (queimada - aquecimento) e a quantidade de matéria orgânica no solo quando comparadas a áreas sem influência antrópica, a matéria orgânica retém umidade, aumenta a agregação de material e retarda a taxa de infiltração de água no solo. Esses solos passam por 
outros processos de preparação como a aragem (que diminui o nível de compactação do solo), como essas atividades afetam apenas os primeiros centímetros do solo, apenas essa porção apresenta maiores taxas de $\mathrm{Kv}$, o resto do perfil de solo apresenta resposta padrão/homogênea de Kv aos demais tipos de solo já que suas características físicas e químicas são muito semelhantes.

$\mathrm{Na}$ época da seca da bacia, os dados referentes aos horizontes subsuperficiais (a $50 \mathrm{~cm}$ de profundidade) são mais interessantes: por exemplo, quando comparamos o ponto 95 (área de roça) com o ponto 98 (área de floresta nativa) vemos que a taxa de infiltração do horizonte superficial é a mesma (alto Kv) mas quando analisamos o horizonte subsuperficial vemos que a $\mathrm{Kv}$ do ponto 98 é superior a $\mathrm{Kv}$ do ponto 95. Essa tendência é atribuída ao uso do solo e as práticas culturais; o ponto 95 teve sua vegetação nativa removida, logo, o números, tipo, comprimento e a espessura de raízes de cortavam o horizonte subsuperficial diminuiu, diminuiu também a atividade biológica nesse horizonte, esses fatores influenciam diretamente na condutividade hidráulica do solo. Outro fato pode ser relatado nesse período é quando comparamos os horizontes superficiais do mesmo tipo pedológico mas com usos diferentes. Primeiramente precisamos entender um pouco sobre a dinâmica da utilização do solo na bacia: na época de cheia, o gado que normalmente fica espalhado pela várzea é levado as regiões de pastos mais altos e ali permanece até o período da seca. Por consequência alguns pastos de terra firme apresentam solo muito compactado, especialmente onde há rebanho de búfalo, apresentando assim baixa condutividade hidráulica, como é o caso do ponto 104. Seguindo as práticas culturais locais, posteriormente esse solo vai ser arado e provavelmente recuperar as características físicas originais com maior $\mathrm{Kv}$ (como é o caso do ponto 37).

De forma geral, analisando-se os resultados obtidos, observamos que, de acordo com os ensaios de infiltração realizados, a camada superficial do solo apresenta valores de condutividade hidráulica classificados como: alto a moderado e essa capacidade de infiltração de água no solo diminui com o aprofundamento do perfil. Esse fato é relatado em trabalhos semelhantes feitos na região amazônica (Oliveira et al., 2011 e Riquelme et al., 2012) e em outras localidades que apresentam condições pedológicas semelhantes e comparáveis (por exemplo região do cerrado brasileiro que apresenta os mesmos tipos pedológicos - latossolos) (Demattê et al., 1993; Fiori et al., 2010). Também foi constatado que é possível observar variações de condutividade hidráulica de acordo com o uso do solo (pasto, roça, floresta) e o período hidrológico da Bacia. Infelizmente com a quantidade de dados coletados não foi possível diferenciar as zonas com diferentes $\mathrm{Kv}$ de acordo com o tipo pedológico, ficando claro apenas as diferenças de $\mathrm{Kv}$ entre a zona de várzea (Kv mais baixo nos horizontes mais profundos - gleissolo) e a zona de Terra Firme (latossolos); (os solos próximos a zona de transição várzea/terra firme apresentam condutividade hidráulica 
variável de acordo com a proximidade dos corpos de água). Foram feitos alguns ensaios de infiltração em plintossolos da zona de terra firme mas não foi possível aferir com precisão a $\mathrm{Kv}$ desses solos, estes apresentavam valores de Kv muito baixo. Com a intensificação dos estudos na área e com base nos resultados já obtidos é possível sugerir um mapa de condutividade hidráulica dentro da área de estudo. 


\section{6 - Isótopos de $\partial^{2} \mathrm{H}$ e $\partial^{18} \mathrm{O}$}

Mais de 80 amostras de água (coletadas no rio amazonas, na várzea/lago, igarapés, poços artesianos, bem como a água chuva) foram coletadas em diferentes épocas do ano (durante a cheia da Bacia em junho e julho de 2014 _ FAB. III, na seca em dezembro de 2014 _ FAB. IV e na enchente em maio de 2015 _ FAB. V) (Figura 31)

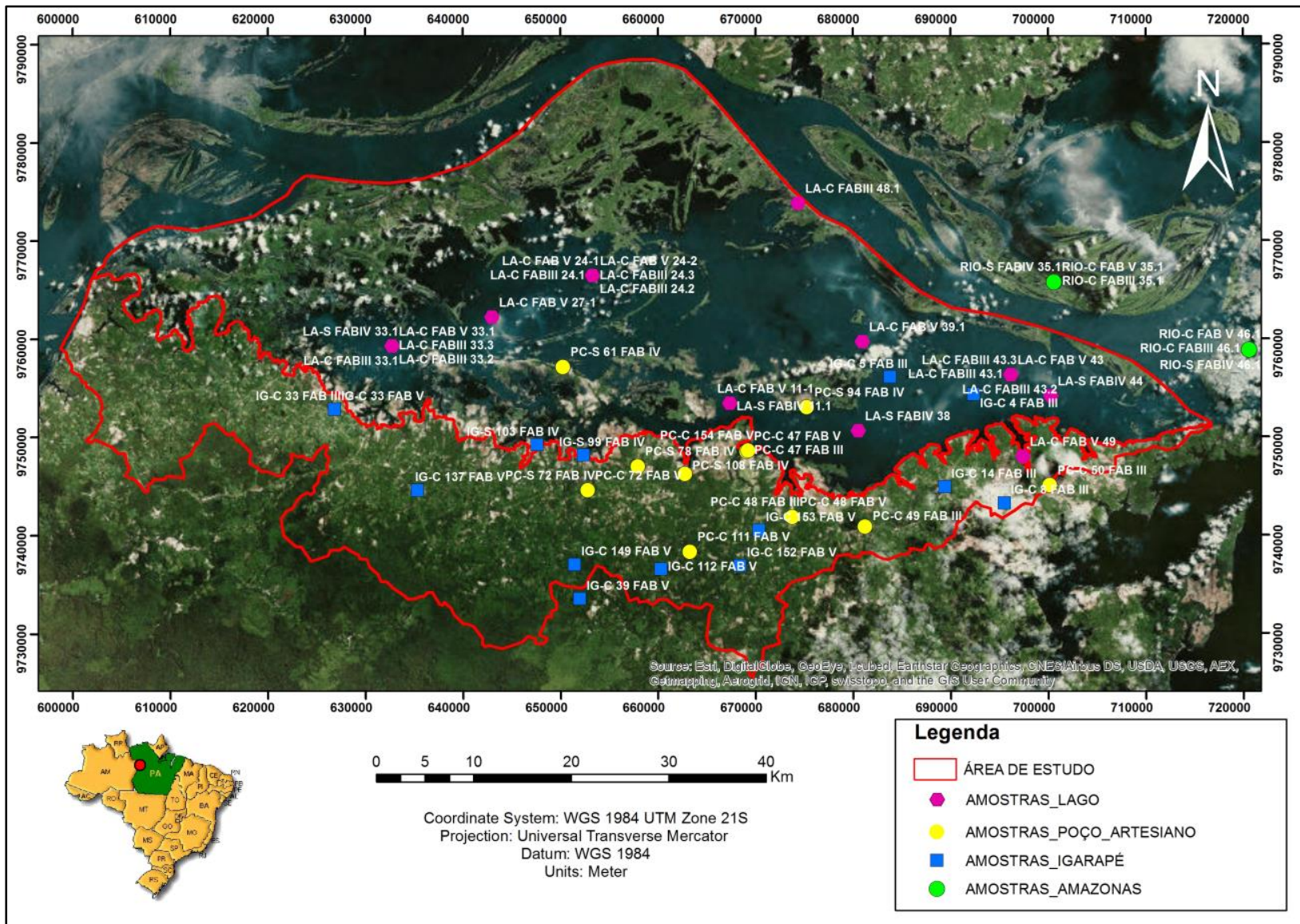

Figura 31 - Distribuição espacial das amostras de água coletadas para análise isotópica.

As águas foram coletadas em diversas localidades a fim de se identificar os principais compartimentos (tipo de água) dentro da bacia de estudo. Baseados nos resultados da literatura e nos obtidos nesse projeto é possível distinguir alguns compartimentos a partir da análise de condutividade elétricas das águas:

- Água meteórica: apresenta condutividade média inferior a $5 \mu \mathrm{S} \mathrm{cm}^{-1}$;

- Água subterrânea e igarapés, apresentam condutividade média intermediária: - $5<$ cond $<25 \mu \mathrm{S} \mathrm{cm}^{-1}$

- Rio Amazonas: apresenta condutividade média superior a $50 \mu \mathrm{S} \mathrm{cm}^{-1}$.

Da mesma forma, os diferentes tipos de água do sistema também podem apresentar assinaturas isotópicas (valores de $\partial^{2} \mathrm{H}$ e $\partial^{18} \mathrm{O}$ ) heterogêneas e, assim, permitem traçar melhor os movimentos e misturas de água na escala da bacia de Curuai e ao longo do ciclo hidrológico. A 
vantagem da utilização de isótopos em relação à condutividade elétrica, é que os isótopos são menos afetados por reações biogeoquímicas que ocorrem na bacia (sorção por exemplo).

Os resultados obtidos a partir da análise das amostras coletadas em campo estão representados na tabela abaixo (Tabela 10 ). Os valores de $\partial^{2} \mathrm{H}$ e $\partial^{18} \mathrm{O}$ variam de $-1,2 \%$ a 106,9\% e de -0,2\%o a -14,2\%o respectivamente. Essas variações são significativas e permitem rastrear fontes e processos associados ao ciclo hidrológico na Bacia.

Tabela 10 - Assinatura isotópica das águas coletadas nos diversos compartimentos de coleta de água. (Legendas: POÇO PC; IGARAPÉ: IG; LAGO GRANDE: LA; CHUVA: CHUVAS; RIO AMAZONAS: RIO) (as terminações C e S refem-se aos períodos de Cheia e Seca respectivamente) (os termos FAB III, FAB IV e FAB V referem-se a campanha de coleta dos pontos: FAB III é a primeira campanha de campo: realizada entre os dias 25 de maio e 6 de junho de 2014, durante a época de cheia da bacia; FAB IV é a segunda campanha de campo: realizada entre os dias 24 de novembro e 3 de dezembro de 2014, durante a época de seca da Bacia;e FAB V é a terceira campanha de campo: realizada entre 4 de maio e 13 de maio de 2015).

\begin{tabular}{|c|c|c|c|c|c|c|c|c|c|c|c|c|c|c|}
\hline \multicolumn{3}{|c|}{ POÇO } & \multicolumn{3}{|c|}{ IGARAPÉ } & \multicolumn{3}{|c|}{ LAGO GRANDE } & \multicolumn{3}{|c|}{ CHUVA } & \multicolumn{3}{|c|}{ RIO AMAZONAS } \\
\hline PONTO & $\mathrm{dD} \%$ & $d^{18} \mathrm{O} \%$ & PONTO & dD\% & $d^{18} \mathrm{O} \%$ & PONTO & dD\% & $d^{18} \mathrm{O} \%$ & PONTO & dD\% & $d^{18} \mathrm{O} \%$ & PONTO & dD\% & $d^{18} O \%$ \\
\hline PC-C 47 FAB III & $-36,55$ & $-6,40$ & IG-C 4 FAB III & $-35,33$ & $-6,24$ & LA-C FABIII 24.1 & $-45,40$ & \begin{tabular}{|l|}
$-7,39$ \\
\end{tabular} & CHUVAS & $-29,69$ & \begin{tabular}{|l|}
$-5,80$ \\
\end{tabular} & RIO-C FABIII 35.1 & $-46,07$ & $-7,82$ \\
\hline PC-C 48 FAB III & $-36,50$ & $-6,39$ & IG-C 5 FAB III & $-36,30$ & $-6,36$ & LA-C FABIII 24.2 & $-47,35$ & $-7,68$ & CHUVAS & $-28,77$ & $-5,97$ & RIO-C FABIII 46.1 & \begin{tabular}{|l|}
$-48,19$ \\
\end{tabular} & $-7,95$ \\
\hline PC-C 49 FAB III & $-39,29$ & $-6,80$ & IG-C 8 FAB III & $-35,95$ & $-6,27$ & LA-C FABIII 24.3 & $-46,47$ & $-7,59$ & CHUVAS & \begin{tabular}{|l|l|}
47,90 \\
\end{tabular} & $-8,18$ & RIO-S FABIV 35.1 & $-27,89$ & $-5,67$ \\
\hline PC-C 50 FAB III & $-46,25$ & $-7,56$ & IG-C 14 FAB III & $-37,18$ & $-6,49$ & LA-C FABIII 33.1 & $-44,73$ & $-7,19$ & CHUVAS & $-11,4$ & $-2,3$ & RIO-S FABIV 46.1 & $-29,94$ & $-5,74$ \\
\hline PC-S 05 FAB IV & $-23,48$ & $-4,05$ & IG-C 33 FAB III & $-36,89$ & $-6,55$ & LA-C FABIII 33.2 & $-44,59$ & $-7,40$ & CHUVAS & $-5,7$ & $-0,2$ & RIO-C FAB V 35.1 & $-39,97$ & $-6,32$ \\
\hline PC-S 61 FAB IV & $-26,84$ & $-4,75$ & IG-S 99 FAB IV & $-36,34$ & $-5,73$ & LA-C FABIII 33.3 & $-47,25$ & $-7,53$ & CHUVAS & $-37,1$ & $-6,8$ & RIO-C FAB V 46.1 & $-41,38$ & $-6,57$ \\
\hline PC-S 72 FAB IV & $-39,22$ & $-6,98$ & IG-S 103 FAB IV & $-36,59$ & $-5,96$ & LA-C FABIII 43.1 & $-47,05$ & $-7,92$ & CHUVAS & $-85,4$ & $-11,8$ & & & \\
\hline PC-S 78 FAB IV & $-42,62$ & $-7,43$ & IG-C 3 FAB V & $-37,30$ & $-5,99$ & LA-C FABIII 43.2 & $-46,29$ & $-7,30$ & CHUVAS & $-3,8$ & $-1,6$ & & & \\
\hline PC-S 94 FAB IV & $-31,46$ & $-5,32$ & IG-C 29 FAB V & $-34,36$ & $-5,86$ & LA-C FABIII 43.3 & $-45,56$ & $-7,29$ & CHUVAS & $-7,5$ & -2 & & & \\
\hline PC-S 108 FAB IV & $-36,97$ & $-6,49$ & IG-C 33 FAB V & $-36,09$ & $-6,27$ & LA-C FABIII 48.1 & $-47,60$ & $-7,94$ & CHUVAS & $-11,6$ & $-1,9$ & & & \\
\hline PC-C 47 FAB V & $-46,08$ & $-7,49$ & IG-C 39 FAB V & $\mid-34,80$ & $-6,20$ & LA-C FABIII 50.1 & $-47,42$ & $-7,59$ & CHUVAS & $-17,4$ & $-2,2$ & & & \\
\hline PC-C 48 FAB V & $-35,53$ & $-6,24$ & IG-C $50 \mathrm{FAB} \mathrm{V}$ & $-46,51$ & $-7,45$ & LA-C FABIII 51.1 & $-48,97$ & $-7,97$ & CHUVAS & $-1,2$ & $-1,3$ & & & \\
\hline PC-C 72 FAB V & $-31,98$ & $-5,63$ & IG-C 112 FAB V & $-37,21$ & $-6,59$ & LA-S FABIV 11.1 & \begin{tabular}{|l|}
$-8,56$ \\
\end{tabular} & $-1,55$ & CHUVAS & $-18,8$ & -3 & & & \\
\hline PC-C 111 FAB V & $-37,56$ & $-6,62$ & IG-C 137 FAB V & $-37,85$ & $-6,74$ & LA-S FABIV 33.1 & $-21,06$ & $-4,13$ & CHUVAS & $-30,4$ & $-4,6$ & & & \\
\hline PC-C 154 FAB V & $-34,25$ & $-6,12$ & IG-C $149 \mathrm{FAB} \mathrm{V}$ & $-37,72$ & $-6,59$ & LA-S FABIV 38 & \begin{tabular}{|l|}
8,57 \\
\end{tabular} & $-1,73$ & CHUVAS & $-13,9$ & $-3,1$ & & & \\
\hline & & & IG-C 152 FAB V & $-36,62$ & $-6,42$ & LA-S FABIV 44 & $-21,42$ & $-4,14$ & CHUVAS & $-46,8$ & -7 & & & \\
\hline & & & IG-C 153 FAB V & $-35,06$ & $-6,18$ & LA-C FAB V 11-1 & $-40,15$ & $-6,42$ & CHUVAS & $-52,3$ & $-8,1$ & & & \\
\hline & & & IG-C 154 FAB V & $-39,77$ & $-6,32$ & LA-C FAB V 24-1 & $-42,15$ & $-6,75$ & CHUVAS & $-69,4$ & $-9,7$ & & & \\
\hline & & & & & & LA-C FAB V 24-2 & $-41,29$ & $-6,56$ & CHUVAS & $-106,9$ & $-14,2$ & & & \\
\hline & & & & & & LA-C FAB V 27-1 & $-41,41$ & $-6,78$ & CHUVAS & $-40,1$ & $-6,6$ & & & \\
\hline & & & & & & LA-C FAB V 33.1 & $-41,55$ & $-6,70$ & CHUVAS & $-36,8$ & -6 & & & \\
\hline & & & & & & LA-C FAB V 39.1 & $-39,75$ & $-6,33$ & CHUVAS & $-22,3$ & $-4,1$ & & & \\
\hline & & & & & & LA-C FAB V 43 & $-40,87$ & $-6,64$ & CHUVAS & $-11,4$ & $-2,9$ & & & \\
\hline & & & & & & LA-C FAB V 49 & $-39,01$ & $-6,61$ & CHUVAS & $-22,1$ & $-4,2$ & & & \\
\hline & & & & & & LA-C FAB V 444.1 & $-41,76$ & $-6,69$ & CHUVAS & $-29,3$ & $-5,2$ & & & \\
\hline & & & & & & LA-C FAB V 777.1 & $-40,73$ & $-6,63$ & CHUVAS & $-4,3$ & $-1,2$ & & & \\
\hline
\end{tabular}

Plotando a totalidade dos valores de $\partial^{2} \mathrm{H}(\partial \mathrm{D})$ e $\partial^{18} \mathrm{O}$, podemos observar um comportamento padrão na resposta dos isótopos da água que compõem o sistema, estes estão alinhados ao longo da "reta" de fracionamento isotópico (dito de Craig (1961) (Figura 32). 


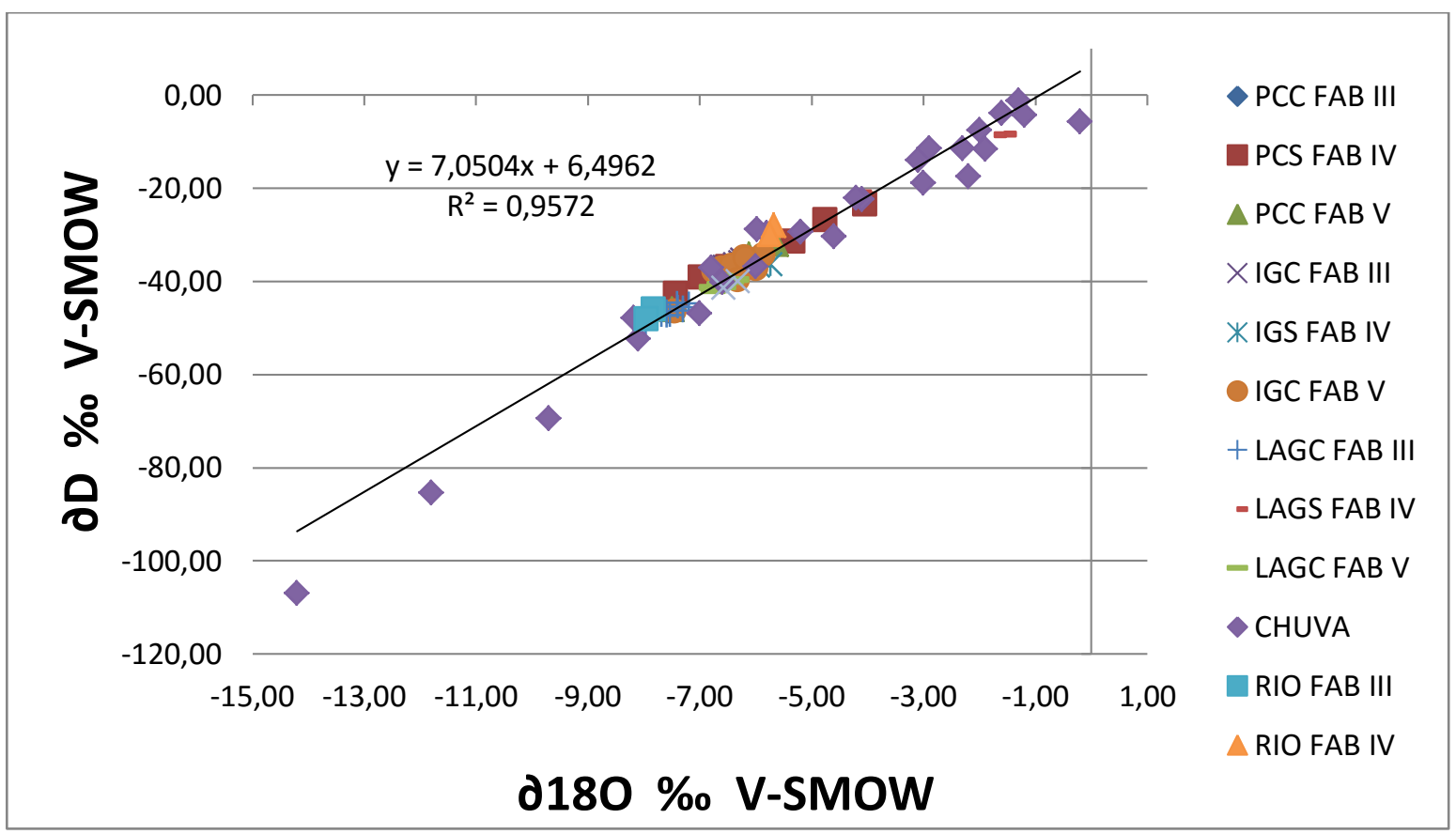

Figura 32 - $\partial^{18} O$ em função do $\partial D$ de todas as amostras coletadas.

Analisando todos os dados de forma conjunta nota-se apenas as diferenças isotópicas entre os períodos de cheia (pontos representados com a nomenclatura de final FAB III, amostras coletadas na cheia de 2014, e FAB V, amostras coletadas na cheia de 2015) e de seca da bacia (pontos representados com a nomenclatura de final IV, essas amostras foram coletadas no período da seca de 2014), e que a assinatura geral é típica de ambiente de clima tropical;

Mas quando analisamos os dados separadamente podemos agrupá-los em diferentes compartimentos de influência:

1) Água Meteórica: A assinatura isotópica das águas da chuva coletadas na área de estudo estão alinhadas sob uma reta de fracionamento isotópico que por sua vez apresenta uma resposta semelhante a "reta meteórica mundial" determinada por Craig (1991) e Rozanski et al.(1993) (Figura 33).

Observa-se que as assinaturas isotópicas das chuvas variam de $-0,2 \%$ a $-14,2 \%$ o $\partial^{18} \mathrm{O}$ e de $-1,2 \%$ a $-106,9 \%$ o $\partial^{2} \mathrm{H}$, apresentando resposta típica de regiões de clima tropical definida por Craig (1991) e Rozanski et al. (1993). Assim, sem surpresa, as assinaturas isotópicas das águas da chuva da Bacia do Lago Grande de Curuai apresentam assinaturas isotópicas pesadas, típicas de regiões tropicais (quentes). As águas da chuva apresentam uma variação isotópica muito grande e abrangem toda a composição das demais águas presentes no sistema (Figura 32). Podemos assim concluir que nessa região as águas meteóricas não constituem um compartimento “distinguível” no sistema da Várzea de Curuai. 


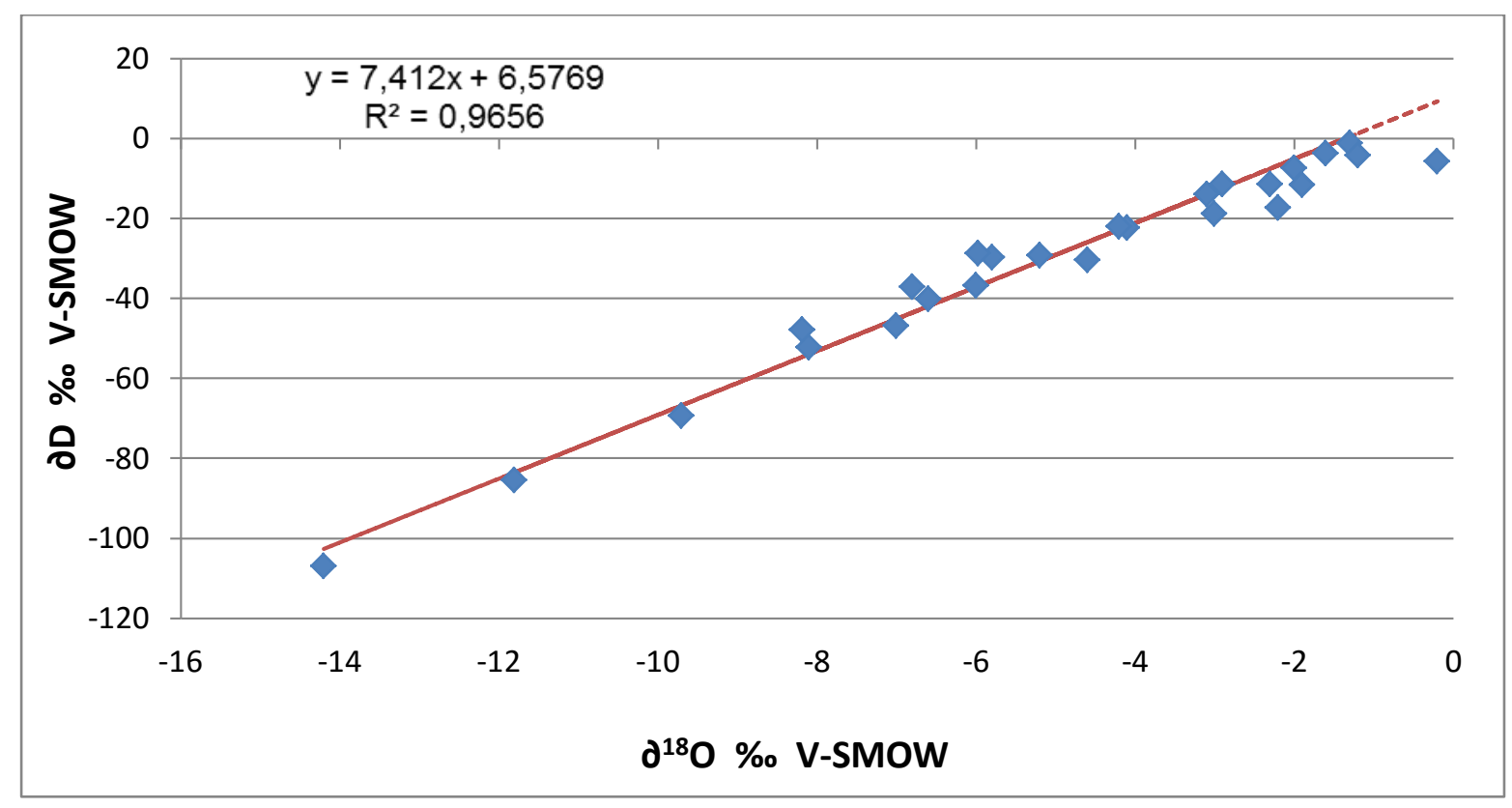

Figura 33 - $\partial^{18} \mathrm{O}$ em função do $\partial \mathrm{D}$ de todas as amostras de chuvas coletadas. Os losangos azuis representam as amostras de água da chuva coletadas em campo; a reta vermelha representa a reta mundial das chuvas proposta por Craig $e t$ al. (1991).

2) Rio Amazonas: As assinaturas isotópicas das águas do Rio Amazonas apresentam clara diferença entre os período de período de cheia (assinatura média: 43,90 \%o $\partial \mathrm{D}$ e 7,16 \%o $\partial^{18} \mathrm{O}$ ) e de seca (assinatura média: $\partial \mathrm{D}-28,91 \%$ e $218 \mathrm{O}-5,70 \%$ ). Na Figura 34 os pontos azuis e verdes representam coletas realizadas na cheia (FAB III e FAB V), mas em anos diferentes e os pontos vermelhos representam as coletas realizadas no período da seca (FAB IV) (Figura 34). Com base nesses resultados observa-se que durante o período da seca o Rio Amazonas é mais enriquecido em isótopos pesados (que são os últimos isótopos a evaporar e os primeiros a precipitar) e durante a cheia a concentração de isótopos pesados diminui, resultado do aumento de volume de água no rio e da mistura com águas menos enriquecidas em isótopos pesados. Fica difícil tirar conclusões a respeito das águas do rio Amazonas porque ele integra águas de diversas bacias de escala regional (ex: águas do Rio Negro e águas do Rio Solimões). 


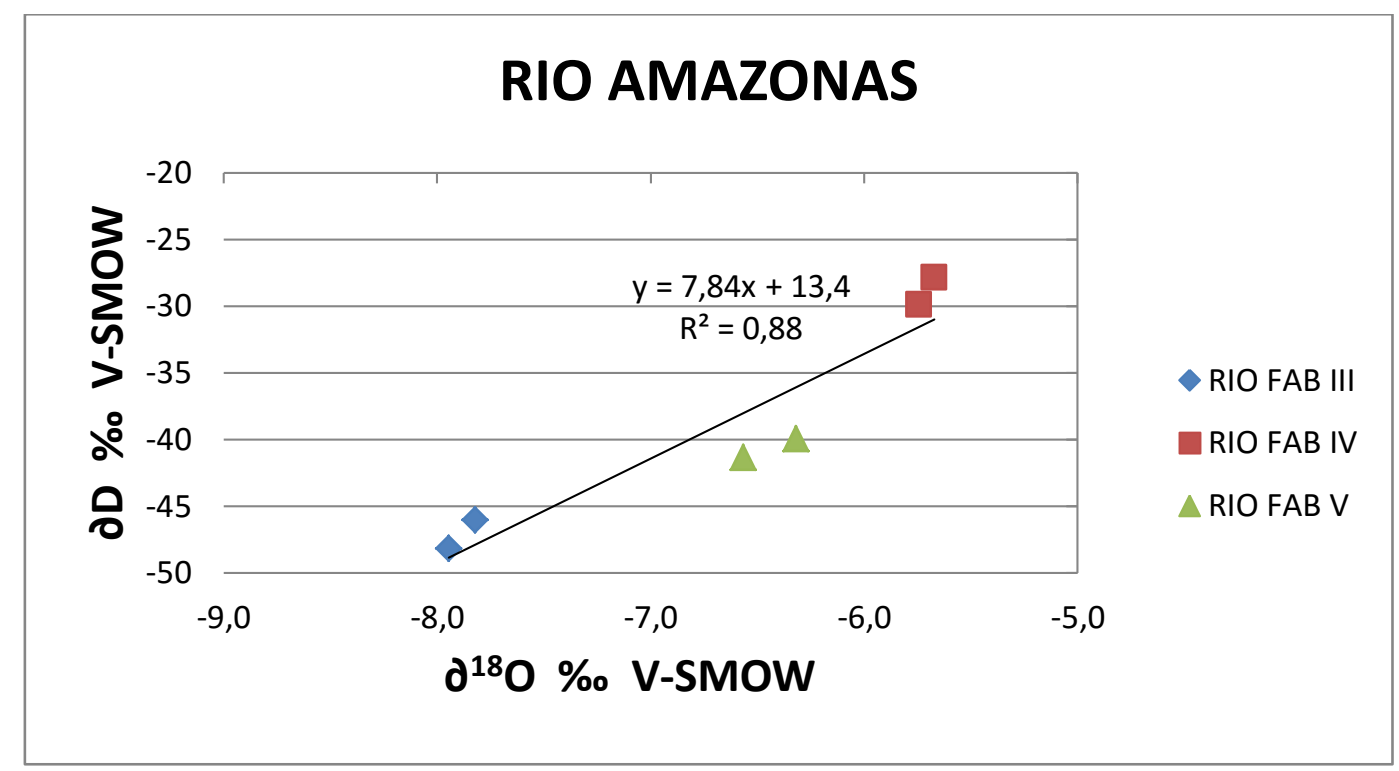

Figura $34-{ }^{18} \mathrm{O}$ em função do $\partial \mathrm{D}$ de todas as amostras do Rio Amazona. Os pontos em verde e em azul representam a resposta isotópica da água do Rio na cheia e em vermelho tem-se a resposta da água do Rio durante a seca. Ano de coleta e época seria melhor que FAB

Observando atentamente a relação entre os dois pontos de coletas no rio Amazonas, podemos notar que para as três campanhas de amostragem, a assinatura isotópica do ponto 46 coletada no rio Amazonas abaixo da várzea é sempre sutilmente mais leve que a assinatura isotópica do ponto 35. Estes resultados analisados separadamende dos demais pontos sugerem que a várzea libera no rio Amazona águas de assinatura isotópica mais leve mas quando analisase o contexto geral da bacia observa-se que essa variação não é resultado direto das águas proveninetes da bacia de Curuai já que a bacia apresenta uma assinatura isotópica mais pesada que o rio.

3) Poços artesianos: As águas de poço artesiano foram coletadas em várias localidades ao longo da área de estudo e é possível observar uma nítida variação da assinatura isotópica dessas águas tanto na escala da bacia como dentro da mesma época de coleta de amostras/ciclo hidrológico (cheia) e essa variação fica mais nítida ainda quando compara-se diferentes períodos do ciclo (cheia, em azul (PC C-FAB III) e em verde (PC C-FAB V), e seca, em vermelho (PC SFAB IV). É possível observar variações até mesmo dentro do mesmo poço (ponto 72) em diferentes períodos de coleta, ex: PC.S-72 e PC.C-72 (Figura 35).

Comparando as assinaturas isotópicas das águas subterrâneas dessas 3 épocas é possível observar que as águas subterrâneas são mais enriquecimento em isótopos pesados durante o período da seca comparado a enchente (fato esse já esperado devido as condições físicas da região e aos processos de fracionamento isotópico - já que os isótopos pesados são os últimos a evaporar, tendem a se permanecer no estado líquido, resultando no enriquecimento aparente em isótopos pesados). 
A variação isotópica das águas subterrâneas é maior durante a seca. Esta diferença entre o período de enchente e seca sugere que o processo de recarga dos poços é diferente nessas duas estações. Essa diferença também pode ser explicada se considerando-se uma maior mistura/homogeneização das águas quando o nível de água do aquífero é mais alto (cheias), e de fato, durante as duas enchentes estudadas, as assinaturas isotópicas das águas subterrâneas são mais homogêneas sugerindo uma homogeneização maior das águas de chuvas (de assinaturas diferentes) e assim maior mistura de águas.

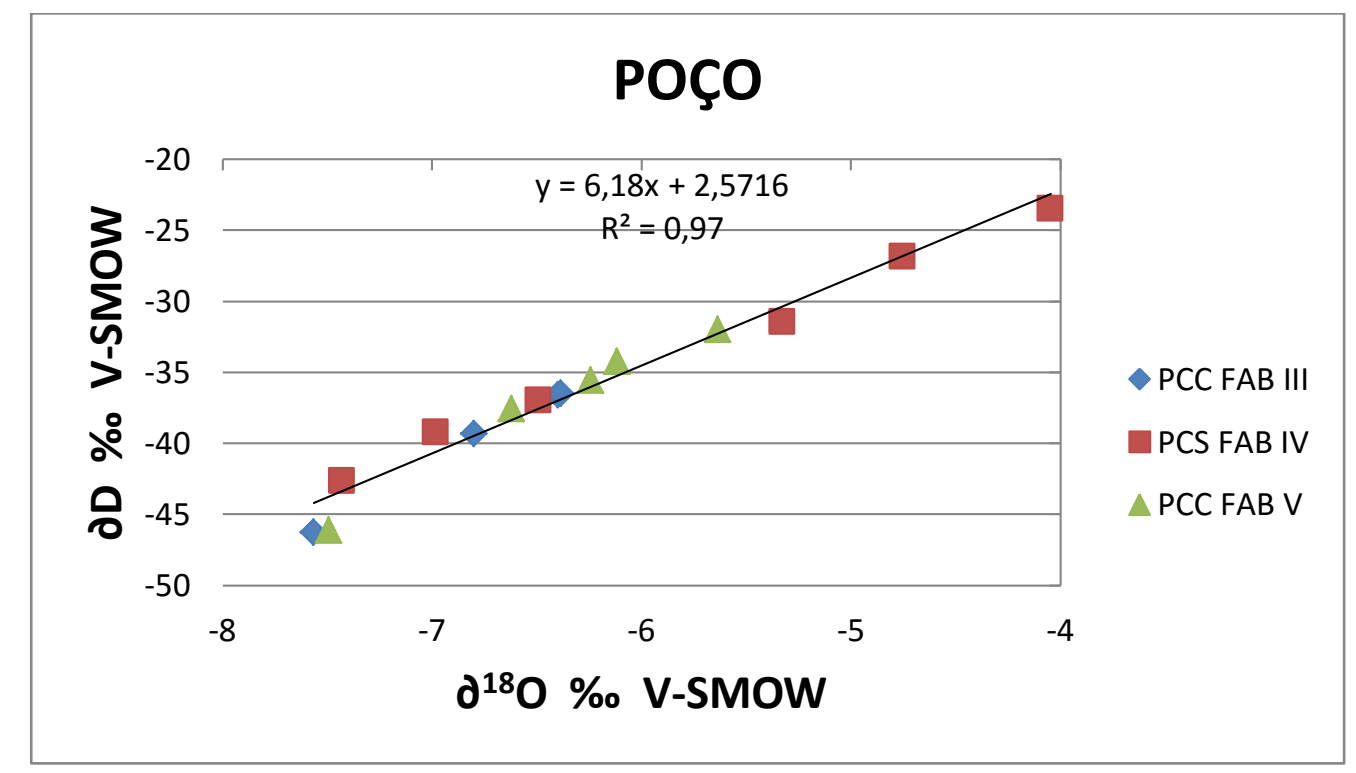

Figura 35- $\partial^{18} \mathrm{O}$ em função do $\partial \mathrm{D}$ de todas as águas subterrâneas da bacia em duas fases do ciclo hidrológico: cheia (representadas pelas cores azul -losango azul-, ano de 2014, e verde - triângulo verde- 2015) e seca 2014 (pontos em vermelho - quadrado vermelho).

4) Igarapés: No período da cheia (FAB III e FAB V) e da seca (FAB IV) os valores médios de $\partial^{18} \mathrm{O}$ são respectivamente de $-6,38 \%$ e $-5,85 \%$ (Tabela 10). Primeiramente nota-se que independente do período do ano, os igarapés apresentam uma variação de assinatura isotópica muito pequena (tanto em relação às águas subterrâneas quanto em relação às águas das chuvas) (Figura 36). Os igarapés constituem assim um polo de composição bastante estável; isso pode ser explicado conforte a última hipótese (referente às águas subterrâneas): há a mistura das águas subterrâneas à medida que elas circulam até os igarapés (nascentes) e desse modo temos uma homogeneização das assinaturas isotópicas das águas dos igarapés.

Como todos os outros polos, os igarapés apresentam significativas mudança de volume durante os períodos de seca e cheia da Bacia, porém as assinaturas isotópicas permanecem constante ao longo do ciclo hidrológico. Assim, acredita-se que as águas de chuvas se infiltram e recarregam o aquífero mais superficial; essas águas continuam circulando, misturando-se até o igarapé e a zona de várzea. Este padrão esta em acordo com um modelo hidrológico simples e 
tem como base uma rápida circulação das águas subterrâneas na parte de Terra Firme (fato possível considerando-se os valores de Kv dessa zona).

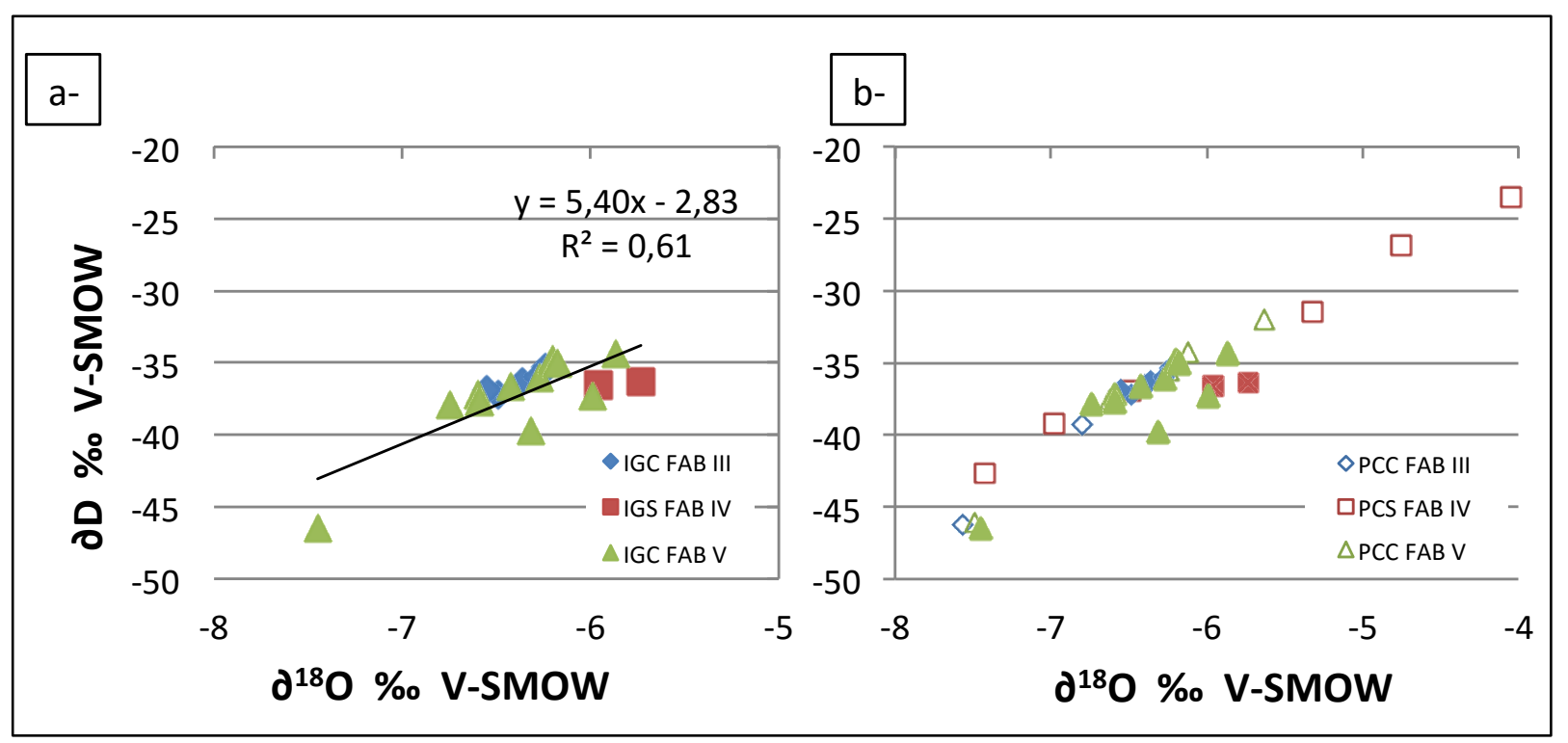

Figura 36 - a- $\partial^{18} O$ em função do $\partial D$ de todos os Igarapés do Lago Grande de Curuai. Os pontos em verde e em azul representam a resposta isotópica da água na cheia e em vermelho tem-se a resposta da água dos igarapés durante a seca. b- $\partial^{18} \mathrm{O}$ em função do $\partial D$ de todas as águas subterrâneas e igarapés da área de estudo (os pontos em verde e em azul representam a resposta isotópica da água na cheia e em vermelho tem-se a resposta da água dos igarapés durante a seca).

- Lago (Lago Grande de Curuai): As amostras coletadas no Lago nos diferentes períodos estudados apresentam assinaturas isotópicas diferentes. Pode-se ressaltar melhor essa diferença quando compara-se as águas do lago durante as cheias (FAB III e FAB V) apresentando um $\partial^{18} \mathrm{O}$ médio de $-7,52 \%$ e a seca, $\partial^{18} \mathrm{O}$ médio de -2,89 \% V-SMOW (Figura 37).

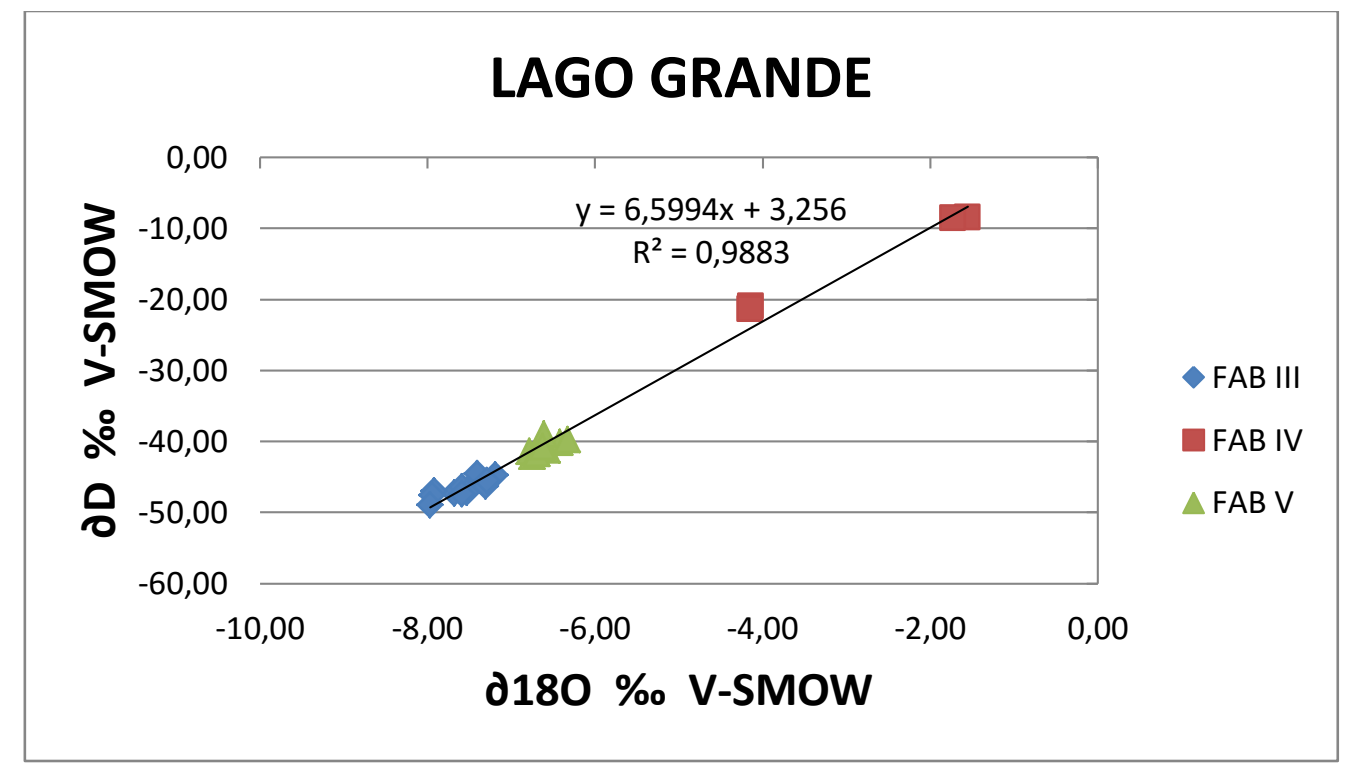

Figura 37 - $\partial^{18} \mathrm{O}$ em função do $\partial D$ de todas as águas do Lago Grande de Curuai.

As assinaturas do lago na época cheia (LA-C FAB III e LA-C FAB V) apresentam uma composição intermediária entre o polo amazonas e o polo igarapé. Este resultado, já esperado 
considerando modelo hidrológico estabelecido, revela a contribuição de pelo menos esses dois polos na composição da água do lago. Como a assinatura isotópica do lago está mais próxima da assinatura do Amazonas interpretasse uma maior contribuição do rio amazonas nessa época. Este resultado esta de acordo com o balanço hídrico do Lago grande de Curuai e as interpretações feitas a partir de outros traçadores tais como condutividade elétrica (Bonnet et al., 2008, Ruddorf et al., 2014).

Estas feições são particularmente melhor demonstradas considerando apenas as assinaturas isotópicas da campanha FAB III, ilustradas na Figura 38.

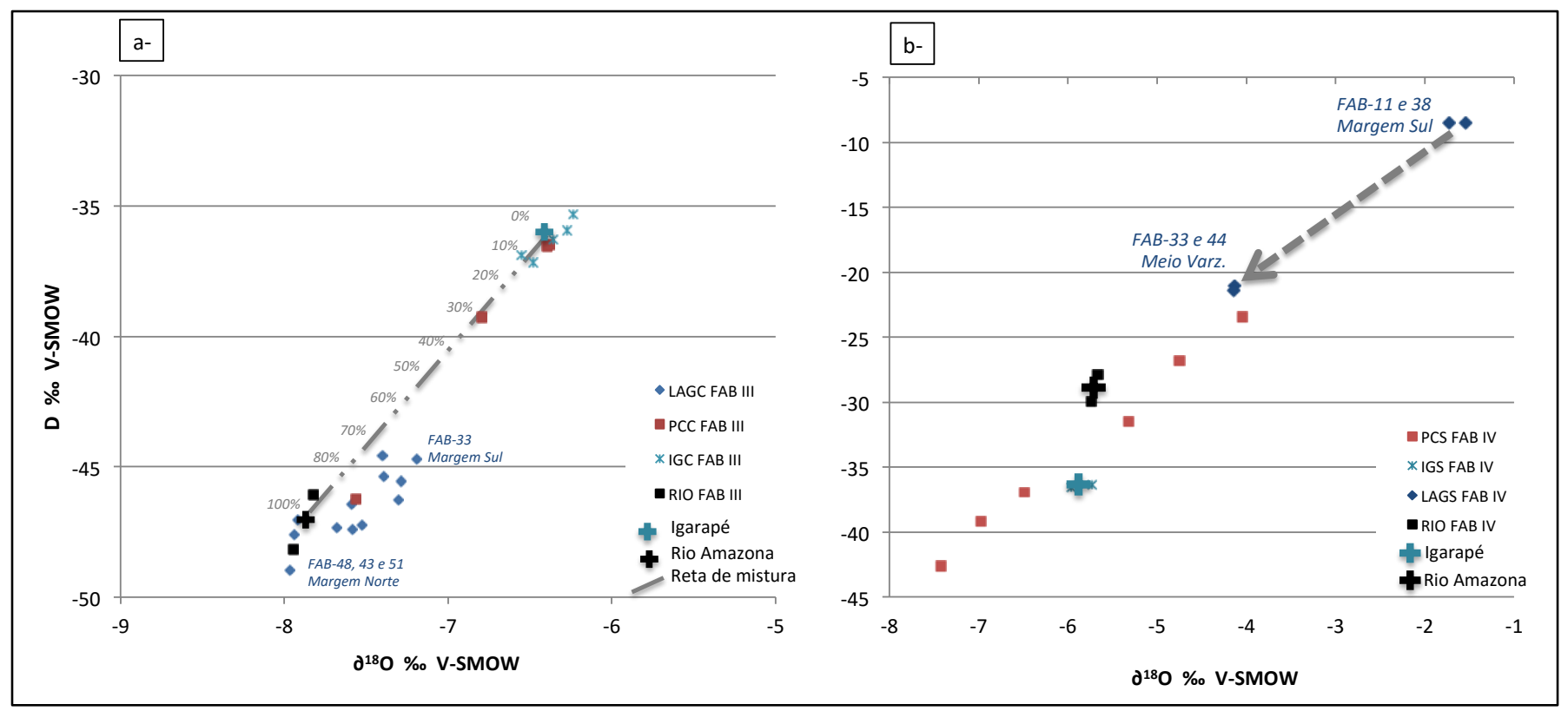

Figura 38 - a- $\partial^{18} \mathrm{O}$ em função do $\partial \mathrm{D}$ de todas as águas coletadas durante a cheia de 2014 (FAB III). A linha tracejada representa o grau de mistura da água entre esses dois compartimentos. b- $\partial^{18} \mathrm{O}$ em função do $\partial \mathrm{D}$ de todas as águas coletadas durante época de seca 2014 . As cruzes (+) azul e preta representam, respectivamente, os compartimentos Igarapé e rio Amazonas.

Observando as assinaturas das águas do lago mais minuciosamente é possível observar uma tendência a assinaturas mais leves nas águas da margem norte e mais pesadas na margem sul, demonstrando a maior influência das águas do Rio Amazona na parte norte do lago e inversamente dos Igarapés no sul (Figura 38). Considerando apenas esse dois polos como fontes de água para o abastecimento do lago, temos que a assinatura média do lago durante o período de cheia $\left(-43,97 \partial \mathrm{D} \%\right.$ e $-7,13 \partial \partial^{18} \mathrm{O} \%$ o é muito mais próxima a assinatura a assinatura média do Amazonas (-43,90 $\partial \mathrm{D} \%$ e $-7,16 \partial^{18} \mathrm{O} \%$ ) do que a assinatura média dos igarapés $(-37,18 \partial \mathrm{D} \%$ e $-6,41 \partial^{18} \mathrm{O} \%$ ) o que demonstra maior influência do Amazonas sobre o Lago de Curuai nesse período.

Assim podemos calcular que as águas mais próximas da margem norte (mais influenciadas pelo rio Amazonas) apresentam praticamente $100 \%$ de suas águas provenientes do 
rio Amazonas e reciprocamente, as águas do lago mais próximas da margem sul apresentam 70\% de suas águas provenientes do rio Amazonas e 30\% da Terra Firme. Podemos notar que esses resultados para a época cheia estão de acordo com cálculos realizados (balanço e modelagem hidrológico) por Bonnet et al. (2008) a partir dos dados in situ e de satélite adquiridos entre 1997 e 2003.

Já durante a seca podemos observar que as águas coletadas no lago apresentam assinaturas mais pesadas (assinatura média: -14,90 $\partial \mathrm{D} \%$ e $-2,89 \partial^{18} \mathrm{O} \%$ ) que estão fora do intervalo de assinatura isotópica constituída pelos polos Amazonas e Igarapés (+ água subterrânea, que dessa vez apresenta certa divergência de valores com os igarapés como já explicado acima)

Considerando a forte taxa de evaporação nessa época e o completo ou parcial isolamento do lago em relação a Rio Amazonas, poderíamos estabelecer duas hipóteses:

1) as águas do lago poderiam apresentar assinatura semelhante do rio Amazonas;

2) as águas do lago poderiam apresentar assinaturas isotópicas alteradas por evaporação ( fracionamento em isótopos fora da reta mundial de Craig: $\partial \mathrm{D}=8,13^{*} \partial^{18} \mathrm{O}+10$.).

Porém as assinaturas isotópicas das quatro águas do lago coletadas estão alinhadas com a reta local e enriquecidas em isótopos pesados em relação com assinaturas isotópicas tanto do rio Amazonas quanto dos Igarapés e dos Poços. Assim, os dados coletados não estão de acordo com uma dessas hipóteses. Observando em detalhe, duas águas do Lago (pontos 33 e 44) apresentam assinaturas isotópicas semelhantes à água proveniente de poço, e assim podem ser "alimentadas" por águas subterrâneas (Figura 38). Podemos notar que esses dois pontos são os mais a Norte, próximo da margem Norte perto do rio Amazonas, o que não era esperado.

Para explicar as assinaturas isotópicas pesadas das águas do lago nessa época teríamos que considerar um compartimento de água ainda não considerado e não amostrado. Pela maior proximidade das assinaturas isotópicas do Lago e das águas subterrâneas podemos propor a hipótese que este novo compartimento corresponde a um fluxo de água subterrânea. Considerando a assinatura isotópica das águas coletadas nos poços da Várzea, esse novo compartimento poderia corresponder a uma água subterrânea mais profunda ou mais conectada com aquífero regional. Pelo momento, considerando os dados disponíveis, fica difícil discutir mais essas assinaturas isotópicas. A prorrogação desses estudos isotópicos na região poderia permitir aumentar nosso banco de dados na região e assim esclarecer a situação.

De maneira geral, os isótopos se mostraram eficientes para rastrear as fontes e os processos (principalmente de mistura) entre os diferentes tipos de águas da bacia de Curuai. Este 
estudo confirmou a forte influencia do Rio Amazona na hidrologia da bacia, especialmente durante as enchente. Os isótopos também permitiram correlacionar a infiltração e circulação das águas de chuvas da Terra Firme até a zona de Várzea.

As observações locais (por exemplo, o nível das águas dos poços mais próximos da Várzea corresponde ao nível da Várzea durante a enchente) e o modelo hidrológico estabelecido nessas regiões mostram que a relação hidrológica entre os lençóis freáticos locais (Terra firme) e o lago grande depende da estação. De fato, quando o nível do rio Amazonas é baixo, a maioria dos lagos está "seca" e apenas um "corredor" de água do rio Amazonas atravessa a Várzea de Curuai. Nesse contexto em que as águas subterrâneas vão recarregar os igarapés e assim a Várzea, temos nesse cenário uma maior influência das águas provenientes da Terra Firme. Reciprocamente, durante a cheia, um grande volume de água do rio Amazonas circula através da Várzea, desta maneira, com uma maior mistura de águas na bacia as colaborações dos demais polos ficam mascaradas, tanto no contexto da bacia quanto entre si, como é o caso das águas subterrâneas e igarapés. 


\section{6 - Conclusão}

1 - Esse trabalho permitiu aumentar o conhecimento científico sobre os solos da região, identificar suas principais características físico-químicas e mineralógicas e elaborar um mapa pedológico específico para a área de estudo (Figura 28).

Geologicamente, a área de estudo pode ser dividida em duas zonas: Zona de Terra Firme e Zona de Várzea. A área apresenta litologia correspondente à Formação Alter do Chão, Cretáceo (Cunha et al.1994). Esta formação composta por arenitos arcoseanos, pelitos, argilitos, arcóseos, quartzo-arenitos e brechas intraformacionais sob a forma de estratos esbranquiçados a avermelhados formou-se devido a depósitos sedimentares em ambiente flúvio-lacustre durante o terciário. Essa é a geologia predominante na parte sul da área, zona de terra firme (arenitos de granulometria média a grossa da Formação Alter do Chão). Na parte norte, zona de várzea, observa-se a predominância de depósitos de aluviões recentes (Quaternário) com granulometria variável de areia grossa a argila.

Os solos da zona de várzea são derivados desses aluviões, passam a maior parte do ano submersos e/ou em condições de encharcamento e podem ser classificados como gleissolos háplicos (podem ser eutróficos ou distróficos e apresentam argilas de alta e de baixa atividade). Esses solos são fortemente afetados pelos pulsos de inundação (resultado das enchentes do rio Amazonas) que atingem a bacia de estudo e estão constantemente recebendo e agregando materiais que são trazidos por esses pulsos (sedimentos, minerais, matéria orgânica), por isso apresentam características diferentes dos solos de terra firme. Os solos de várzea são solos formados por material recente; seus horizontes superficiais apresentam granulometria fina (argilosa - siltosa). Os minerais encontrados nesses horizontes frequentemente são atribuídos aos materiais trazidos pelos pulsos de inundação (resultado da mistura de águas provenientes da Cordilheira dos Andes e dos escudos cristalinos que delimitam a Bacia Amazônica) e essa composição diversa explica as características geoquímicas desse solo. Os minerais característicos dessa zona são: quartzo, caulinita, ilita e anatásio; por vezes é possível observar solos com presença de vermiculita, esmectita, ortoclásio, microclínio e outros.

Os solos da zona de terra firme são derivados da Formação Alter do Chão e já passaram por intensos processos de intemperismo. Em sua maioria são classificados como latossolos (latossolo amarelo/ latossolo vermelho, ambos distróficos). Esses solos apresentam uma mineralogia típica de solos tropicais intemperizados, composta por quartzo e caulinita (compatível com a litologia e com as atividades biológicas da área), textura arenosa e as análises químicas são compatíveis com a mineralogia da área. 
2 - Ao longo do estudo foi possível identificar algumas alterações relacionadas ao ecossistema de Várzea, mais especificamente aos solos influenciados pela crescente ocupação humana.

A população local utiliza mais intensamente os solos da zona de terra firme, sendo que os solos da zona de várzea são utilizados de forma esporádica (frequentemente na época de seca da bacia) e normalmente para pastagem do gado.

Após uma análise geral dos solos (tanto da zona de várzea como da zona de terra firme) submetidos a diferentes usos (pastagem, roça, agrofloresta, área de desmatamento e zonas sem interferência humana direta) foi observado que independente do uso aplicado ao solo as características mineralógicas desses solos não passaram por alterações perceptíveis como a dimunuição de argilominerais nos horizontes. Já as características físicas apresentam modificações quando ao uso do solo. As áreas utilizadas para pastagem apresentam maior grau de compactação do horizonte superficial do solo que as demais áreas, e as áreas de desmatamento apresentam menor umidade nos horizontes superficiais do solo. As variações químicas dos solos de acordo com seu uso estão mais frequentemente relacionadas a quantidade de matéria orgânica (MO) nos horizontes superficiais. As áreas de floresta nativa (sem influência humana) apresentam maior quantidade de MO que áreas de pastagem. Infelizmente essas alterações são as que mais impactam a população e a vegetação já que as comunidades locais ainda não conseguiram desenvolver técnicas de manejo que auxiliem na recuperação da fertilidade do solo.

Como já mencionado no capítulo de introdução, a floresta amazônica é praticamente autossustentável (apresenta altas taxas de reciclagem de nutrientes) e a interferência humana altera esse ciclo biológico, o que resulta em zonas com solos arenosos e empobrecidos, com horizontes orgânicos limitados. Essa perda de fertilidade parece estar associada a mudanças de vegetação: de áreas de floresta para áreas com vegetação rasteira e de baixo porte (quando não em áreas com ausência de vegetação).

3 - Os ensaios de infiltração realizados não permitiram alcançar todos os objetivos iniciais dessa dissertação, mas por meio deles foi possível ampliar o conhecimento a respeito da percolação da água nos solos da região.

Observou-se que a condutividade hidráulica varia de acordo com o uso do solo (pasto, roça, floresta) e o período hidrológico da Bacia. Como esperado, a camada superficial do solo apresenta valores de condutividade hidráulica classificados como altos a moderados e essa capacidade de infiltração diminui com o aprofundamento do perfil. Esses dados sugerem mudanças físicas nas condições do perfil, mudanças essas que podem ser relacionadas ao aumento no grau de compactação e umidade no perfil de solo. 
Analisando as zonas de estudo de forma individual, temos que:

- A zona de terra firme apresenta condutividade hidráulica quase que homogênea (de alta a moderada nos horizontes superficiais e de moderada a baixa nos horizontes mais profundos). Tentou-se fazer alguns ensaios nos plintossolos da zona de terra firme mas foram mal sucedidos, com base nas observações de campo esses solos apresentam uma condutividade hidráulica muito baixa. Os plintossolos são pouco frequentes na área de estudo, mas com mais estudos talvez seja possível definir sua Kv e delimitar zonas específicas para esses solos.

○ Os ensaios de infiltração realizados na zona de várzea foram feitos durante o período de seca. De forma geral, esses solos apresentam condutividade hidráulica baixa a muito baixa (essa condutividade apresentaria valores menores se os ensaios fossem realizados na época de chuva da Bacia). Esses solos são mal drenados, apresentam granulometria fina (silte/argila). Mesmo na época de seca, boa parte desses solos mantém um alto nível de umidade ao longo do perfil e normalmente estão localizados próximos a corpos d'água (lençol freático próximo à superfície).

Infelizmente com a quantidade de dados coletados não foi possível diferenciar novas zonas com diferentes $\mathrm{Kv}$ de acordo com o tipo pedológico, ficando claro apenas as diferenças de $\mathrm{Kv}$ entre a zona de várzea (Kv mais baixo nos horizontes mais profundos - gleissolo) e a zona de Terra Firme (latossolos).

4 - O uso de traçadores isotópicos acoplado aos ensaios de infiltração permitiu entender um pouco mais sobre as fontes e a circulação das águas que abastecem a bacia de estudo.

De maneira geral, os isótopos se mostraram um traçador eficiente para rastrear as fontes e os processos (principalmente de mistura) entre os diferentes tipos de águas da bacia de Curuai. Este estudo confirmou a forte influência do rio Amazonas na hidrologia da bacia, especialmente durante as enchentes.

Além disso, os isótopos permitiram correlacionar a infiltração e circulação das águas de chuvas da Terra Firme até a zona de Várzea.

As observações locais e o modelo hidrológico estabelecido nessa região mostram que a relação hidrológica entre os lençóis freáticos locais (Terra firme) e o Lago depende da estação hidrológica. De fato, quando o nível do rio Amazonas é baixo, a maioria dos lagos estão 'secos' e apenas um “corredor” de água do Rio Amazona atravessa a Várzea de Curuai. Nesse contexto, as águas subterrâneas vão recarregar os igarapés e, assim, a Várzea; temos nesse cenário a maior 
influência das águas provenientes da Terra Firme. Já durante a cheia, um grande volume de água do rio Amazonas circula através da Várzea; nesse contexto, com uma maior mistura de águas na bacia, as colaborações dos demais compartimentos ficam mascaradas, tanto no âmbito da bacia, quanto entre si, como é o caso das águas subterrâneas e igarapés.

5 - Com base em todos os dados gerados nesse trabalho foi possível elaborar um modelo pedológico para a área de estudo.

O modelo esquemático abaixo, é resultado da integração de dados desse estudo e visa explicar melhor as condições geológicas, morfológicas, pedológicas e edáficas da área (Figura 39). Esse perfil representa um transecto típico partindo do centro zona de várzea até o extremo sul da zona de terra firme:

Tabela 11 - Apresentação de forma simplificada da integração dos dados do estudo.

\begin{tabular}{|l|c|c|}
\hline ZONAS & ZONA DE TERRA FIRME & ZONA DE VÁRZEA \\
\hline LITOLOGIA & Fm. ALTER DO CHÃO & DEPÓSITOS DE ALUVIÃO \\
\hline PERÍODO & TERCIÁRIO & QUATERNÁRIO \\
\hline GRANULOMETRIA & AREIA & ARGILA/SILTE \\
\hline MINERALOGIA & MIN. SIMPLES (QTZ,CAU) & MIN. COMPLEXA (QTZ, CAU, 2:1) \\
\hline TIPO DE SOLO & LATOSSOLOS & GLEISSOLOS \\
\hline CONDUTIVIDADE HIDRÁULICA & ALTA KV & BAIXA KV \\
\hline USO DO SOLO & ELEVADO & BAIXO \\
\hline VEGETAÇÃO & FLORESTA,PASTO & VEG. RASTEIRA - PASTOS \\
\hline
\end{tabular}




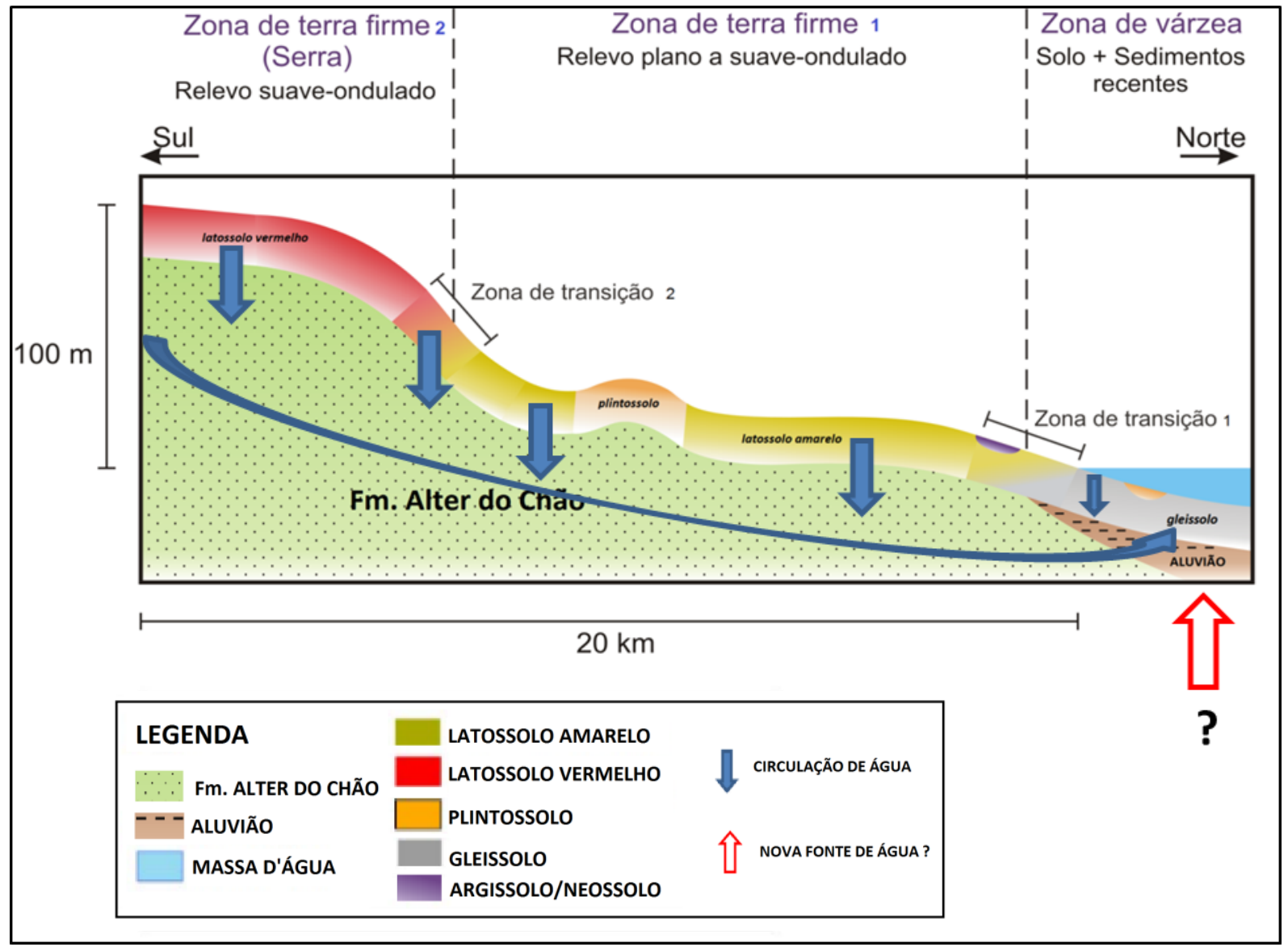

Figura 39 - Representação esquemática do transecto típico da área de estudo. Apresentação da litologia, pedologia e a condutividade hidráulica local. As proporções e escalas utilizadas são meramente ilustrativas.

A zona de várzea é caracterizada por aluviões depositados sobre a Formação Alter do Chão. A maioria dos solos dessa zona podem ser classificados como gleissolos háplicos; por vezes, quando o nível da água baixa mais que o de costume, é possível observar manchas de plintossolos nessa área. Essas manchas de plintossolo, chamadas de ilhas durante o período de seca representam porções de terra mais elevadas, onde a Formação Alter do Chão encontra-se mais próxima a superfície e camada de aluvião é menos espessa. De forma geral a Kv dessa zona é classifica como baixa a muito baixa.

Na faixa de transição da zona de várzea para a zona de terra firme (Zona de Transição 1) é possível observar latossolos com mineralogia diferente da mineralogia comumente neles observada (quartzo e caulinita) com minerais como ilíta e anatásio (minerais esses agregados aos solos da várzea e a esses solos da zona de transição por meio dos pulsos de inundação). Próximo a essa zona de transição também é possível observar manchas de argissolo e de neossolo.

A zona de terra firme apresenta litologia correspondente a formação Alter do Chão e os solos dessa zona apresentam características típicas de solos derivados dessa formação: textura arenosa, mineralogia composta basicamente por quarto e caulinita e alta Kv. A zona de terra firme 1 apresenta relevo plano a suave-ondulado. Em algumas porções dessa zona é possível 
observar morrotes com cobertura plintítica (plintossolos) que apresenta relevos intermediários entre a zona de terra firme 1 e 2, pode-se pensar que estes plintossolos representam um nível de uma crosta laterítica antiga mas devido a escassez de dados fica difícil afirmar algo.

$\mathrm{Na}$ zona de transição 2, que marca a passagem da zona de terra firme 1 para a zona de terra firme 2 (que apresenta relevo suave ondulado e fica localizada próxima ao limite sul da área) é possível observar manchas de latossolo vermelho amarelo.

A zona de terra firme 2 é marcada por relevo mais acentuado, vegetação mais preservada e pouca interferência humana. Também está sobre a Formação Alter do Chão. Os seus solos também apresentam textura arenosa e foram classificados como latossolos vermelhos devido a essa ser a coloração predominante nos solos dessa área. A zona de terra firme como um todo está requerida para pesquisa mineral de bauxita, porém foram na zona de terra firme 2 onde os maiores indícios da possível ocorrência dessa commoditie foram observados.

As setas azuis no modelo esquemático representam a circulação de água pela bacia. As setas da zona de terra firme são maiores que a seta da zona de várzea devido a terra firme apresentar uma maior condutividade hidráulica que a zona de várzea. Também é representado por uma seta azul na horizontal a circulação da água da zona de terra firme até a zona de várzea. A seta vermelha representa o novo compartimento que foi sugerido para explicar as assinaturas isotópicas da água do lago durante a seca.

6 - As informações geradas por esse trabalho possibilitaram esclarecer várias informações genéricas a respeito da área e geraram novos questionamentos que somente serão respondidos com a continuação dos trabalhos na região. Com isso, espera-se que este trabalho motive novas pesquisas e novos pesquisadores a conhecer mais essa região que tem tanto para nos ensinar. 


\section{Bibliografia}

AB'SÁBER ,A.: problemas da Amazônia brasileira - Dossiê Amazônia brasileira. Estudos Avançados 19 (53), 2005.

ALBERS, A.P.F., MELCHIADES, F.G., MACHADO, R., BALDO, J.B., BOSCHI, A.O. - Um método simples de caracterização de argilominerais por difração de raios X, 2002.

AMORIM, M.A.: Estudo da sedimentação recente na Várzea do Lago Grande do Curuai, Pará, Brasil. Dissertação (Mestrado em Geoquímica Ambiental). Universidade Federal Fluminense, 150 p, 2006.

ANDERSON, A.- Forest management strategies by rural inhabitants in the Amazon estuary. In: A. GÓMEZPOMPA, T. C. Whitmore and Hadley, M. (eds.), Rain Forest Regeneration and Management. The Parthenon Publishing Group, Paris, pp.: 351- 360pp. 1991.

BARBOSA, G. V.; COSTA, R. C. V.; NATALI FILHO, T.; OLIVEIRA, A. A. B.; GARCIA, M. G. L. Geomorfologia. In: DNPM - Departamento Nacional de Produção Mineral. Brasília. p 167-244. 1978.

BARBOSA, C.C.F.. Sensoriamento remoto da dinâmica da circulação da água do sistema planície de Curuai/Rio Amazonas. Tese (Doutorado em Sensoriamento Remoto). São José dos Campos, INPE. 255 p, 2005.

BARROUX, G.A. Etude biogéochimique d'un système lacustre de la laine d'inondation amazonienne: Cas de la várzea de Curuai (Pará, Brésil). Toulouse, 2006.

BENEDETTI, U; VALE JÚNIOR, J. F.; SCHAEFER, C. E. G.R.; MELO, V. F.; UCHÔA, S. P. Gênese, química e mineralogia de solos derivados de sedimentos pliopleistocênicos e de rochas vulcânicas básicas em Roraima, norte Amazônico. Revista brasileira de ciências do solo, 35:299-312, 2011.

BONNET, M.-P, BARROUX, G., MARTINEZ, J.M, SEYLER, F., MOREIRA-TURCQ, P., COCHONNEAU, G., MELACK, J.M., BOAVENTURA, G., MAURICE-BOURGOIN, L., LEON, J.G., ROUX, E., CALMANT, S., GUYOT, J.L., SEYLER, P. Flooding hydrology in an Amazonian floodplain lake (Lago Grande de Curuai), Journal of Hydrology, v. 349, n. 1-2, p. 18-30, 2008.

BOUCHEZ, J.; GALY, V; HILTOND, R. G.; GAILLARDETA, J.; MOREIRA-TURCQ, P; PÉREZ, M.A; FRANCE-LANORDH, C.; MAURICE, L.: Source, transport and fluxes of Amazon River particulate organic carbon: Insights from river sediment depth-profiles. 2014.

BRANDÃO, V. S. et al. Infiltração de água no solo. 3 ed. Atual e Ampl. Viçosa: UFV, 120p, 2006.

CARNEIRO, F.A. e MANOEL, J. - Hidrogeologia Conceitos e Aplicações. 1997.

COCHRANE, T.T. e P.A. SANCHEZ - Land resources, soils and their management in the Amazon regioon: A state oh knowledge report. P. 137-209. 1982.

CUNHA, P. R. C.; GONZAGA, F. G.; COUTINHO, L. F. C; FEIJÓ, F. J. - Bacia do Amazonas. Biol. Geoc., vol 8:, p 47-55. 1994.

DAEMON, R.F. - Contribuição para a datação da Formação Alter do Chão, Bacia do Amazonas. Rev. Bras. Geo. Vol.5, n.2. p. 78-84. 1975.

DANSGAARD, W.: Stable isotopes in precipitation. Phys. Lab. II, H. C. Orsted Institute, University of Copenhagen. 1964.

DE VOS B, VAN MEIRVENNE M, QUATAERT P, DECKERS J, MUYS B. Predictive quality of pedotransfer functions for estimating bulk density of forest soils. Soil Science Society of America Journal. 2005.

DEMATTÊ, J.L.I. Manejo de solos ácidos dos trópicos úmido da região amazônica. Campinas, Fundação Cargill, 215p. 1988.

DEMATTÊ J.L.I.; DEMATTÊ J.A.M. - Comparações Entre As Propriedades Químicas De Solos Das Regiões Da Floresta Amazônica E Do Cerrado Do Brasil Central, 1993.

DUNNE, T; MERTES, L. A. K.; MEADE, R. H.; RICHEY, J. E.; FORSBERG, B. R. - Exchanges of sediment between the floodplain and channel of the Amazon River in Brazil. Geol. Soc. Of America Bull., vol. 110, p 450-467. 1998.

ELBAZ-POULICHET, F.; SEYLER, P.; MAURICE-BOURGOIN, L; GUYOT, J.L; DUPUY, C - Trace element geochemistry in the upper Amazon drainage basin. Chemical Geology, vol 157. P 319-334. 1999.

EMBRAPA,a Serviço Nacional de Levantamento e Conservação do Solo. Levantamento de Reconhecimento de Baixa Intensidade dos Solos da Aptidão Agrícola das Terras do Projeto de Colonização Apiaú - Território Federal de Roraima, Rio de Janeiro, EMBRAPA, 175p. (Boletim de Pesquisa nº. 14). 1982.

EMBRAPA,b Serviço Nacional de Levantamento e Conservação do Solo. Levantamento de Reconhecimento de Alta Intensidade dos Solos da Aptidão Agrícola das Terras de áreas ao longo da BR-174, na Região do Rio Anuá, Município de Caracaraí T. E. de Roraima. Rio de Janeiro, EMBRAPA. 173p. (Boletim Técnico nº 79). 1982.

EMBRAPA. Centro Nacional de Pesquisa de Solos. Manual de métodos de análise de solo. Rio de Janeiro, 1997. 
EMBRAPA. Centro Nacional de Pesquisa de Solos. Sistema Brasileiro de Classificação de Solos. Rio de Janeiro, 1999.

EMBRAPA. Centro Nacional de Pesquisa de Solos. Sistema Brasileiro de Classificação de Solos. Brasília: 2006.

EMBRAPA, Padronização de métodos para análise granulométrica no Brasil. 2012

FALESI, I.C. - Soils of the Brazilian Amazon. P. 201-209, 1974.

FERREIRA, M. M.; FERNANDES, B.; CURI, N. Influência da mineralogia da fração argila nas propriedades físicas de Latossolos da região Sudeste do Brasil. Revista Brasileira de Ciência do Solo, Viçosa, v. 23, p.515-524, 1999.

FETTER, C.W. Applied Hydrogeology. 3 Ed. New York: MacMillan College Publisher Co., 691 p., 1994.

FILIZOLA, N. - O fluxo de sedimentos em suspensão nos rios da Bacia Amazônica brasileira. Brasília: Agência Nacional de Energia Elétrica - ANEEL (ed.),1999.

FILIZOLA, N.; GUYOT, J. L.; GUIMARÃES, V. S.; MOLINIER, M.; OLIVEIRA, E.; FREITAS, M. A. V. Caracterização Hidrológica da Bacia Amazônica. Manaus In:FREITAS A. R. C. (ed.). Amazônia - Uma perspectiva interdisciplinar I, , 2002.

FILIZOLA N. e GUYOT J.-L. The use of Doppler technology for suspended sediment discharge determinations on the River Amazon at Obidos. Hydrol. Sci. J. 49, 143-153. 2003.

FILIZOLA N. e GUYOT J.-L:Suspended sediment yield in the Amazon basin: an assessment using the Brazilian national data set. Hydrol. Proc. 23, 3207-3215. 2009.

FIORI, J.P.O. - Avaliação de métodos de campo para a determinação de condutividade hidráulica em meios saturados e não saturados. (Dissertação de mestrado - UnB) 2010.

FIORI J.P.O., CAMPOS J.E.G., ALMEIDA L. Variabilidade da condutividade hidráulica das principais classes de solos do Estado de Goiás. 2010.

FISHER, T. R.; PARSLEY, P. E. Amazon lakes: Water storage and nutrient stripping by algae. Limnol. Oceanogr. 24 (3): 547-553, 1979.

FORSBERG, B. R.; DEVOL, A. H.; RICHEY, J. E.; MARTINELLI, L. A.; SANTOS, H. -Factors controlling nutrient concentrations in Amazon floodplain lakes. Limnol. Oceanogr., vol. 33. p 41-56. 1988.

FORSBERG, B.R.; MELACK, J.M.; KEMENES, A. \& BELGER, L. O papel dos ecossistemas aquáticos amazônicos nos ciclos regional e global de carbono. In: II Simpósio em Ecologia "Ciclo do Carbono em Ambientes Aquáticos Continentais", resumos de palestras, Rio de Janeiro, p. 4. 2008.

FREEZE, R.A. e CHERRY, J.A. Groundwater. New York: Prentice Hall, 604 p., 1979.

FREITAS, E.: O solo da Amazônia é pobre em nutrientes, 2006.

FRITSCH, E; G. MORIN; A. BEDIDI; D. BONNIN; E. BALAN; S. CAQUINEAU e G. CALAS: Transformation of haematite and Al-poor goethite to Al-rich goethite and associated yellowing in a ferralitic clay soil profile of the middle Amazon Basin (Manaus, Brazil). European Journal of Soil Science Volume 56, Issue 5, pages 575588, October 2005.

FRITSCH, E.; ALLARD, T.; BENEDETTI, M. F.; NASCIMENTO, N. R. DO; LI,Y.; CALAS, G. 2009. Organic complexition and translocation of ferric iron in podzols of the Negro River watershed. Separetion of secondary Fe species from Al species. Geochimica et Cosmochimica Acta, Inglaterra, v. 73, p. 1813-1825.2009.

GIBBS, R. J .- The Geochemistry of the Amazon River System. Part I. The factors that control the salinity, the composition and the concentration of the suspended solids. Geol. Soc. Am. Bull., vol. 78. p 1203-1232. 1967.

GONÇALVES,D; LEITE,W.C; BRINATTI,A.M.; SAAB, S.C.; IAROSZ, K.C.; MASCARENHAS, Y.P.; CARNEIRO, P.I.B.;E ROSA J.A.: Mineralogia De Um Latossolo Vermelho Distrófico Submetido A Diferentes Manejos Por 24 Anos. 2008.

GOULDING, M. 1993. Flooded Forest Amazon. Scientific American, 268(3): 113-120.

GUIMARÃES, J T F; COHEN, M. C. L.; FRANÇA, M. C.; SILVA, A. K. T.; RODRIGUES, S. F. S: Mineralogical and geochemical influences on sediment color of Amazon wetlands analyzed by visible spectrophotometry, ACTA AMAZONICA 2013.

GUYOT, J.L., QUINTANILLA, J., CALLIDONDE, D; CALLEH, H. - Distribucion regional de la hidroquímica em la cuenca Amazônica de Bolívia, 1992.

GUYOT, J.L.: Hydrochimie Des Fleuves De L'amazonie Bolivienne. 1993.

GUYOT J.-L., JOUANNEAU J.-M., SUARES L., BOAVENTURA G. R., MAILLET N. AND LAGANE C. Clay mineral composition of river sediments in the Amazon Basin. Catena 71, 340-356. 2007.

HORBE, A.M.C; HORBE, M.A; SUGUIO, K - Origem dos depósitos de areias brancas no nordeste de Amazonas. Rev. Bras. Geo. Vol 33, n.1, p.41-50. 2003. 
HORBE A.M.C., PAIVA M.R.P., MOTTA M.B., HORBE M.A.: Mineralogia e geoquímica dos perfis sobre sedimentos neógenos e quaternários da bacia do Solimões na região de Coari - AM. Acta Amazônica, 37:8190. 2007.

HyBAm:. Geodynamical, hydrological and biogeochemical control of erosion/alteration and material transport in the Amazon basin: 2010.

IRION, G. Clay minerals of Amazonian soils. In: The Amazon: limnology and landscape ecology of a mighty tropical river and its basin. SIOLI, H., ed. Dordrecht, Dr. W. Junk Publishers, p.537-579 (Monographiae biologicae, v. 56). 1984.

IRION, G. - Quaternary geological history of the amazon lowlans. Tropical Forests: 1989,

IRION, G.; JUNK, W.J. \& MELLO, A.S.N.J. The large central amazonian river floodplains near Manaus: Geological, climatological, hydrological and geomorphological aspects. 1997.

IRION, G.; BUSH, M.B.; NUNES DE MELLO, J.A.; STÜBEN, D.; NEUMANN, T.; MÜLLER, G.; MORAIS, J.A.; JUNK, W.A multiproxy palaeoecological record of Holocene lake sediments from the Rio Tapajós, eastern Amazonia. Palaeogeography, Palaeoclimatology, Palaeoecology, 240: 523-535. 2006.

JENNY, H. - Factors Of Soil Formation: A System of Quantitative Pedology. Dover Publications, Inc. New York, 1941.

JORDAN, C.F. - Soils of the Amazon rainforest, 1985.

JUNK, W.J. \& HOWARD-WILLIAMS, C. Ecology of aquatic macrophytes in Amazonia. In: Sioli, H. (Ed.). The Amazon: limnology and landscape ecology of a migthy tropical river and its basin. Monographiae Biologicae 56. Dordrecht, Dr. W. Junk Publishers, pp. 269- 293. 1984.

JUNK, W. J. e FURCH, K. - The Physical and Chemical Properties of Amazonian Waters and Theirs Relationships with the Biota. In: G. T. Prance. e T. E. Lovejoy (eds.) Amazonia; Key environments, 1, Editora Pergamon Press,. New York, U.S.A, pp.: 3 - 17pp. 1985.

JUNK, W.J.; BAYLEY, P.B. \& SPARKS, R.E. The flood pulse concept in river- floodplains systems. In: Dodge, D.P. (Ed.) Proceedings of the International Large River Symposium. Canadian Special Publication of Fisheries and Aquatic Sciences, 106, pp. 110-127. 1989.

JUNK, W. J. - Wetlands of tropical South America. In: WHIGHAM, D.; HEJNY, S.; DYKYJOVA, D. (eds.) Wetlands in the Amazon floodplain. Hidrobiologia, vol. 263, p. 155-162. 1993.

JUNK, W. J. 1997a- General aspects of floodplain ecology with special reference to amazonian floodplains. In: JUNK W.J. (ed.) The Central Amazon floodplain: ecology of a pulsing system, Berlin, Springer.. p. 3-20.

JUNK, W.J. 1997b. Structure and function of the large central amazonian river floodplains: synthesis and discussion. In: The central amazon floodplain: ecology of a pulsing system. Springer, Ecological Studies Series, v.216, pp. 455-472.

KEDDY, P.A. \& FRASER, L.H. Introduction: Big is beautiful. In: Fraser, L.H. \& Keddy, P.A. (Eds). The World's Largest Wetlands: Ecology and Conservation. Cambridge (United Kingdom): Cambridge University Press. pp.:1-10. 2005.

KEDDY, P; FRASER, L.H; SOLOMESHCH, A.I.; JUNK, W.J.; CAMBELL, D.R.; ARROYO, M.T.K. e ALHO, C.J.R. Wet and wonderful: the world's largest wetlands are conservation priorities. BioScience, 59 (1): $39-51$. 2009.

KOTSCHOUBEY B., TRUCKENBRODT W., HIERONYMUS B. Génese e evolução das bauxitas do NE do Pará. Nova proposta. In: SBG, Simp. Geol. Amazônia, 4, Belém, Boi. resumos expandidos, p. 272-274. 1994.

KOTSCHOUBEY, B.; DUARTE, A.L.S e TRUCKENBRODT, W.: Cobertura Bauxítica E Origem Do Caulim Do Morro Do Felipe, Baixo Rio Jari, Estado Do Amapá.1999.

LIMA, H.N. Gênese, química, mineralogia e micromorfologia de solos da Amazônia Ocidental. Tese de Doutorado. Pós-Graduação em Solos e Nutrição de Plantas, Universidade Federal de Viçosa. 176 pp. 2001.

LOPES, A.S. Solos sob "cerrado": características, propriedades e manejo. Piracicaba, POTAFÓS, 162p. 1983.

LUCAS, Y. Système pédologiques en Amazonie brésilienne: Equilibres, déséquilibres et transformations. Poitiers, France, 1989. 203 f. Thèse de Doctorat, Université de Poitiers.

LUCAS,Y; LUIZAO, F. J.; CHAUVEL,A; ROUILLER, A; NAHON, D.: The Relation Between Biological Activity of the Rain Forest and Mineral Composition of Soils. 1993.

MACEDO, R.S. Atributos físicos, químicos e mineralógicos de solos com horizonte antrópico (Terra Preta de Índio) em área de várzea do rio Solimões, AM. Manaus, Universidade Federal do Amazonas, 73p. (Dissertação de Mestrado) 2009.

MALAVOLTA, E.; KLIEMANN, H.J. Desordens nutricionais no cerrado. Piracicaba, POTAFÓS, 136p. 1983. 
MARQUES, J., SALATI, E., SANTOS, J.M. - Cálculo da evapotranpiração real na Bacia Amazônica através do método aerológico. Acta Amazônica, vol. 10. n.2, p.357-361, 1980.

MARQUES, J.D.O., LUIZÃO, F.J., TEIXEIRA, W.G., e FERREIRA, S.J.F - Variações do Carbono Orgânico dissolvido e de Atributos Físicos do Solo Sob Diferentes Sistemas de Uso da Terra na Amazônia Central. 2012.

MARTINEZ, J. M., KOSUTH, P.; COCHONNEAU, G.; MAURICE-BOURGOIN, L.; SEYLER, F.; BOURREL, L.; GUYOT, J.L., Application of remote sensing data for the quantification of an Amazon floodplain extension, dynamics and water storage. EGS-AGU-EUG Joint Assembly, Nice, April, France. 2003.

Martinez, J.M. ; Le Toan, T. Mapping of flood dynamics and vegetation spatial distribution in the Amazon flooplain using multitemporal SAR data. Remote Sensing Environ., 108 (3), 209-233. 2007.

MARTINS. P.F.S., CERRI, C.C., VOLKOFF, B., ANDREUX, F - Efeito Do Desmatamento E Do Cultivo Sobre Características Físicas E Químicas Do Solo Sob Floresta Natural Na Amazônia Oriental. Rev. IG, São Paulo, 8$10,11(1), 21-33,1990$.

MAURICE-BOURGOIN, L., MARTINEZ, J.M., GRELAUD, J., BOAVENTURA, G. R., FILIZOLA, N. The role of floodplain in the hydrology and sediment dynamics of the Amazon River. Publication (Ed.), IAHS. IAHS Publication 291, Foz do Iguaçu, Brazil. 2005.

MAURICE-BOURGOIN, L.; BONNET, M.-P.; MARTINEZ, J.-M.; KOSUTH, P.; COCHONNEAU, G.; MOREIRA-TURCQ, P.; GUYOT, J.-L.; VAUCHEL, P.; FILIZOLA, N.; SEYLER, P.. Temporal dynamics of water and sediment exchanges between the Curuaí floodplain and the Amazon River, Brazil. Journal of Hydrology, 335: 140-156. 2007.

MEADE, R. H.; DUNNE, T.; RICHEY, J. E.; SANTOS, U. M.; SALATI, E. - Storage and remobilization of suspended sediment in the lower Amazon River of Brazil. Science, vol. 228, p. 488-490. 1985.

MELACK, J.M. \& HESS, L.L. 2010. Remote sensing of the distribution and extent of wetlands in the Amazon basin. In: Junk, W.J.; Piedade, M.T.F.; Wittmann, F.; Schöngart, J. \& Parolin, P. (Eds.) Amazonian Floodplain Forests: ecophysiology, ecology, biodiversity and sustainable management. Springer, Ecological Studies Series, 210, pp. 43-59.

MELO, V. F. Solos e indicadores de uso agrícola em Roraima: Áreas Indígena Maloca do Flechal e de Colonização do Apiaú. Viçosa, UFV. 145p. (Tese de Doutorado). 2002.

MELO, V. F. et al. Caracterização física, química e mineralógica de solos da Colônia Agrícola do Apiaú (Roraima, Amazônia) sob diferentes usos e após queima. Revista brasileira de ciência do solo, 30:1039-1050, 2006.

MERMET, J. M. "Is it still possible, necessary and beneficial to perform research in ICP-atomic emission spectrometry?".J. Anal. At. Spectrom.20: 11-16.doi:10.1039/b416511j. Retrieved 2007-08-31. 2005.

MERTES, L. A. K.; DUNNE, T.; MARTINELLI, L.A. - Channel-floodplain geomorphology along the SolimõesAmazon River, Brazil. Geol. Soc. of America Bull., vol. 108, p. 1089- 1107. 1996.

MOLINIER, M.; GUYOT, J. L.; DE OLIVEIRA, E.; GUIMARÃES, V. \& CHAVES, A. Hidrologia da Bacia do Rio Amazonas. In: A Água em Revista, v. 2, n. 3, pp. 31-36. Rio de Janeiro: CPRM. 1994.

MOLINIER, MICHEL; GUYOT, JEAN LOUP; CALLEDE, JACQUES; DE OLIVEIRA, EURIDES; GUIMARÃES, VALDEMAR SANTOS AND FILIZOLA, NAZIANO PANTOJA. Um exemplo de pesquisa franco-brasileira : a hidrologia da bacia amazônica. França-Flash Meio Ambiente. 1996.

MOLINIER, M.; GUYOT, J.L.; CALLÈDE, J.; GUIMARÃES, V.; OLIVEIRA, E.; FILIZOLA, N. - Hydrologie du bassin amazonien,. In: THERY H. (ed.) Environnement et développement en Amazonie brésilienne, Publ. Belin, Paris, p. 24-41. 1997.

MOREIRA-TURCQ, P.; JOUANNEAU, J. M.; TURCQ, B.; SEYLER, P.; WEBER, O. \& GUYOT, J. L. Carbon sedimentation at Lago Grande de Curuai, a floodplain lake in the low Amazon region: insights into sedimentation rates. Palaeogeography, Palaeoclimatology, Palaeoecology, 214(1-2): 27-40. 2004.

MOREIRA, M. L. C.; VASCONCELOS, T. N. N. Mato Grosso: solos e paisagens. Cuiabá/MT: Entrelinhas, 2007.

MOSER, H. AND STICHLER, W. Deuterium measurements on snow samples from the Alps. Isotope Hydrology, IAEA, pp. 43-57, Vienna 1970.

NEVES, L. E. "Estudo prático de argilas por difratometria de raios X" - Boletim Técnico da Petrobrás 11,1 (1968) 123-135.

OLIVEIRA, M.C.F., ABUQUERQUE, M.F., CIQUEIRA, H.M.R., JÚNIOR, J.A.S., COSTA, A.C.L.,ASSIS, L.M., - Comportamento Da Taxa De Infiltração De Água No Solo Em Área De Floresta Tropical. 2011

PÉREZ, M.A.P. Biogeoquímica da Várzea do Lago Grande de Curuai, Rio Amazonas, Pará, Brasil: caracterização, origem, ciclagem e destino do material orgânico e inorgânico. Universidade Federal Fluminense. Tese (doutorado - Geoquímica Ambiental). 266p. 2008. 
PIEDADE, M.T.F.; SCHÖNGART, J. \& JUNK, W. J. O manejo sustentável das áreas alagáveis da Amazônia Central e as comunidades herbáceas aquáticas. Uakari, v1. pp. 44- 55. 2005.

PIEDADE, M. T.F.; JUNK, W.J; D’ÂNGELO, S.A.; WITTMANN, F.; SCHÖNGART, J.; DO NASCIMENTO, K.M.B. \& LOPES, A. Aquatic herbaceous plants of the Amazon floodplains: state of the art and research needed. Acta Limnologica Brasiliensia, v. 22, 2, p. 165-178. 2010.

PIMENTEL, J. V. F. Níveis de água, matéria orgânica e cobertura morta na produção de mudas de cumaru (Amburana cearensis). 2008. Dissertação (Mestrado em Engenharia Agrícola). Universidade Federal de Campina Grande, Campina Grande, 2008.

PUTZER, H - The geological evolution os the Amazon basin and its mineral resources. In: SIOLI, H. e JUNK W., (eds) The Amazon, Berlin, Dordrecht press. p. 15-46. 1984.

RADAMBRASIL - Projeto RADAMBRASIL. Levantamento de Recursos Naturais, 10 (Folha S. ${ }^{\text {a }}$ - Santarém). Rio de Janeiro. Departamento Nacional de Produção Mineral, p. 522 . 1976.

RAFFLES, H. - Exploring the anthropogenic Amazon: estuarine landscape transformations in Amapá, Brasil. New York Botanical Garden Press, p.355-370. 1999.

RASANEN, M., LINNA, A., IRION, G., HERNANI, L.R., HUAMAN, R.V., WESSELINGH, F., Geologia Y geoformas de la zona de Iquitos, Perú. Annales Universitatis Turkuensis Ser All vo114, p. 59-137. 1988.

REGO, R.S. ; VIEIRA, L.S.; AMARAL FILHO, Z.P.; SANTOS, P .L. ; LOPES, D.N. ; REIS, C.M; GAMA, J.R.N.F.; COSTA, N.F. ; SERRUYA, L.M. Estudo detalhado do solo de uma área do município de Capitão Poço-PA. Belém, Instituto de Desenvolvimento Econômico-Social do Estado do Pará. 117p. (Série Cadernos Paraenses, 9). 1973.

RICHEY, J. E.; MERTES, L. A. K., DUNNE, T., VICTORIA, R., FORSBERG, B. R., TANCREDI, A. C. F. N. S.; OLIVEIRA, E. Source and routing of the amazon river flood wave. Global Biogeochemical Cycles, 3(3): 191204, 1989.

RIQUELME, A.M., LUZ, L.H.B.P., FILHO, E.P.S. - COMPORTAMENTO DA TAXA DE INFILTRAÇÃO DE ÁGUA NO SOLO EM ÁREA DE FLORESTA TROPICAL.2012.

ROSS, JURANDYR .L.S. Relevo Brasileiro: uma nova proposta de classificação, 1990.

ROZANSKI, K., ARAGUAS-ARAGUAS, L., AND GONFIANTINI, R.: Isotopic patterns in modem global precipitation, in: Climate Change in Continental Isotopic Records - Geophysical Monograph 78, edited by: Swart, P. K., Lohman, K. C., McKenzie, J., and Savin, S., American Geophysical Union, Washington, DC, 136, 1993.

RUDORFF, C. M., MELACK, J. M., BATES, P. D. Flooding dynamics on the lower Amazon floodplain: 1. Hydraulic controls on water elevation, inundation extent, and river-floodplain discharge. 2014.

SALATI E, MARQUES J: Climatology of the Amazon Region. Pages 85-126 in The Amazon. Limnology and landscape ecology of a mighty tropical river and its basin. Berlin, W. Junk publisher, p.763. 1984.

SALCEDO, A.K.M.: Riqueza E Densidade De Macroinvertebrados Aquáticos Associados Às Macrófitas Aquáticas Nos Lagos De Várzea Janauacá (Am) E Grande De Curuai (Pa) Da Amazonia Central Brasileira (Tese de Doutorado). 2011.

SAMPAIO, A., NORTHFLEET, A. Estratigrafia e correlação das bacias sedimentares brasileiras. In: XXVII CONGRESSO SOCIEDADE BRASILEIRA DE GEOLOGIA. Aracajú, 1973. Anais... Aracaju: [s.e.], p. 189206. 1973.

SANCHEZ, P.A. Properties and management of soils in the tropics. New York, John Wiley, 618p. 1976.

SANTOS , P. S., "Ciência e tecnologia de argilas v. 1". ed. Edgard Blücher Ltd. 1989.

SIOLI, H. Valores de pH de águas amazônicas. Boletim do Mueseu Paraense Emilio Goeldi;Geologia, Serie 1, 39 p. 1957.

SIOLI, H. - Hydrochemistry and geology in the Brazilian Amazon region. Amazoniana, vol. 1, p.267-277. 1968.

SIOLI, H - The Amazon and its main effluentes: Hydrograph, morphology of the river courses and rivers types. Dordrecht: W. Junk publisher, 1984, p. 127 - 165

SOMBROEK, W.G., PM FEARNSIDE e M. CRAVO - Geographic assessment of carbon stored in Amazonian terrestrial ecosystems and their soils in particular. p, 375-389. 1984.

TOCKNER et al., - TOCKNER, K., MALARD, F.; WARD, J. V. An extension of the flood pulse concept. Hydrol. Process. 14: 2861-2883, 2000.

TREVISAN, G. V. \& FORSBERG, B.R. Relationships among nitrogen and total phosphorus, algal biomass and zooplankton density in the central Amazonia lakes Hydrobiologia, 586: 357- 365. 2007. 
VALE JÚNIOR, J. F. Pedogênese e alterações dos solos sob manejo itinerante, em áreas de rochas vulcânicas ácidas e básicas, no Nordeste de Roraima. Viçosa, MG, Universidade Federal de Viçosa, 1999. 198p. (Tese de Doutorado).

VAN BREEMEN, N. e BUURMAN, P. Soil Formation. 2002.

VIEIRA, L.S.; SANTOS, P.C.J. Amazônia: seus solos e outros recursos naturais. São Paulo, Ed. Agronômica Ceres, 416p. 1987.

VIERS, J.; BARROUX, G.; PINELLI, M.; SEYLER, P.; OLIVA, P.; DUPRÉ, B.; BOAVENTURA, G. R. - The influence of the Amazonian floodplain ecosystems on the trace element dynamics of the Amazon River mainstem (Brazil). Science of Total Environment, vol. 339, p. 219-232. 2005.

WILSON, M., BATES, P., ALSDORF, D., FORSBERG, B., HORRITT, M., MELACK, J., FRAPPART, F.; FAMIGLIETTI, J., Modeling large-scale inundation of Amazonian seasonally flooded wetlands. Geophysical Research Letters 34 (15), 2007.

WITTMANN, F.; SCHÖNGART, J. \& JUNK, W. J. 2010. Phytogeography, species diversity, community structure and dynamics of central amazonian floodplain forests. In: Junk, W.J.; Piedade, M.T.F.; Wittmann, F.; Schöngart, J. \& Parolin, P. (eds.) Amazonian Floodplain Forests: ecophysiology, ecology, biodiversity and sustainable management. Springer, Ecological Studies Series, v.210, pp. 43-59. 


\section{Anexos}

Anexo 1 - Tabela de pontos coletados na área de estudo (cor cinza $-1^{\mathrm{a}}$ campanha, verde $-2^{\mathrm{a}}$ campanha, laranja $-3^{\mathrm{a}}$ campanha de amostragem; coordenadas X e Y foram obtidas por GPS em projeção UTM - WGS 84, zona 21S).

\begin{tabular}{|c|c|c|c|c|c|c|c|c|c|c|c|}
\hline PONTO & COORD X & COORD Y & PONTO & COORD $X$ & COORD Y & PONTO & COORD $X$ & COORD Y & PONTO & COORD $X$ & COORD Y \\
\hline 1 & 688868 & 9741652 & 31 & 629077 & 9748488 & 61 & 650229 & 9757170 & 91 & 679356 & 9751610 \\
\hline 2 & 691405 & 9741890 & 32 & 628621 & 9749717 & 62 & 632787 & 9760002 & 92 & 676155 & 9753235 \\
\hline 3 & 692036 & 9742097 & 33 & 626851 & 9752841 & 63 & 631275 & 9757443 & 93 & 675623 & 9752672 \\
\hline 4 & 692501 & 9742327 & 34 & 632296 & 9747348 & 64 & 631165 & 9757283 & 94 & 675226 & 9753045 \\
\hline 5 & 692680 & 9742157 & 35 & 642693 & 9741087 & 65 & 634397 & 9754638 & 95 & 640919 & 9740964 \\
\hline 6 & 697538 & 9743580 & 36 & 643339 & 9740322 & 66 & 634422 & 9754461 & 96 & 650560 & 9743506 \\
\hline 7 & 696044 & 9743261 & 37 & 649355 & 9741678 & 67 & 635817 & 9759309 & 97 & 650606 & 9744648 \\
\hline 8 & 695498 & 9743235 & 38 & 648836 & 9744108 & 68 & 649333 & 9772469 & 98 & 650594 & 9744776 \\
\hline 9 & 691873 & 9742002 & 39 & 651969 & 9733527 & 69 & 647314 & 9760328 & 99 & 652364 & 9748141 \\
\hline 10 & 688582 & 9747569 & 40 & 650981 & 9735975 & 70 & 647283 & 9759992 & 100 & 652275 & 9748742 \\
\hline 11 & 687112 & 9748608 & 41 & 646368 & 9734266 & 71 & 653531 & 9761709 & 101 & 652953 & 9748985 \\
\hline 12 & 687120 & 9748571 & 42 & 648594 & 9748076 & 72 & 652768 & 9744586 & 102 & 650563 & 9743950 \\
\hline 13 & 688847 & 9746690 & 43 & 648657 & 9746582 & 73 & 652486 & 9748133 & 103 & 647617 & 9749203 \\
\hline 14 & 689408 & 9744898 & 44 & 644582 & 9733531 & 74 & 653318 & 9749112 & 104 & 648699 & 9747552 \\
\hline 15 & 690072 & 9743940 & 45 & 651256 & 9736489 & 75 & 654866 & 9745364 & 105 & 661750 & 9743285 \\
\hline 16 & 686398 & 9741389 & 46 & 671418 & 9734716 & 76 & 655580 & 9744591 & 106 & 662596 & 9744606 \\
\hline 17 & 685753 & 9741214 & 47 & 669064 & 9748566 & 77 & 658110 & 9746366 & 107 & 662908 & 9746842 \\
\hline 18 & 681892 & 9741050 & 48 & 673722 & 9741863 & 78 & 657904 & 9747022 & 108 & 662754 & 9746263 \\
\hline 19 & 680633 & 9740737 & 49 & 681202 & 9740857 & 79 & 658654 & 9750707 & 109 & 660641 & 9749996 \\
\hline 20 & 669600 & 9745505 & 50 & 700162 & 9745062 & 80 & 662508 & 9747881 & 110 & 648794 & 9751211 \\
\hline 21 & 667459 & 9744758 & 51 & 707102 & 9745699 & 81 & 669761 & 9744883 & 111 & 696599 & 9749245 \\
\hline 22 & 666545 & 9742771 & 52 & 658587 & 9742860 & 82 & 672244 & 9771100 & 112 & 696952 & 9746014 \\
\hline 23 & 666142 & 9742666 & 53 & 658023 & 9740760 & 83 & 668924 & 9765275 & 113 & 676802 & 9742296 \\
\hline 24 & 648995 & 9745082 & 54 & 658120 & 9738430 & 84 & 675919 & 9763932 & 114 & 676637 & 9736742 \\
\hline 25 & 643674 & 9742736 & 55 & 657655 & 9736329 & 85 & 681957 & 9762235 & 115 & 632581 & 9744055 \\
\hline 26 & 642495 & 9741529 & 56 & 670249 & 9740649 & 86 & 682874 & 9758658 & 116 & 631522 & 9742333 \\
\hline 27 & 639115 & 9740040 & 57 & 667535 & 9736352 & 87 & 684263 & 9757786 & & & \\
\hline 28 & 634026 & 9746669 & 58 & 666659 & 9731023 & 88 & 682435 & 9755587 & & & \\
\hline 29 & 632850 & 9748352 & 59 & 658544 & 9743950 & 89 & 680544 & 9755671 & & & \\
\hline 30 & 629237 & 9743490 & 60 & 649055 & 9757234 & 90 & 681478 & 9754230 & & & \\
\hline
\end{tabular}


Anexo 2 - Diagrama de atividades baseados nas etapas para realizar as análises das amostras em fração argila. (Fonte: Quadro diagrama obtido durante a realização do curso "Mineralogia de argilas" da UnB).

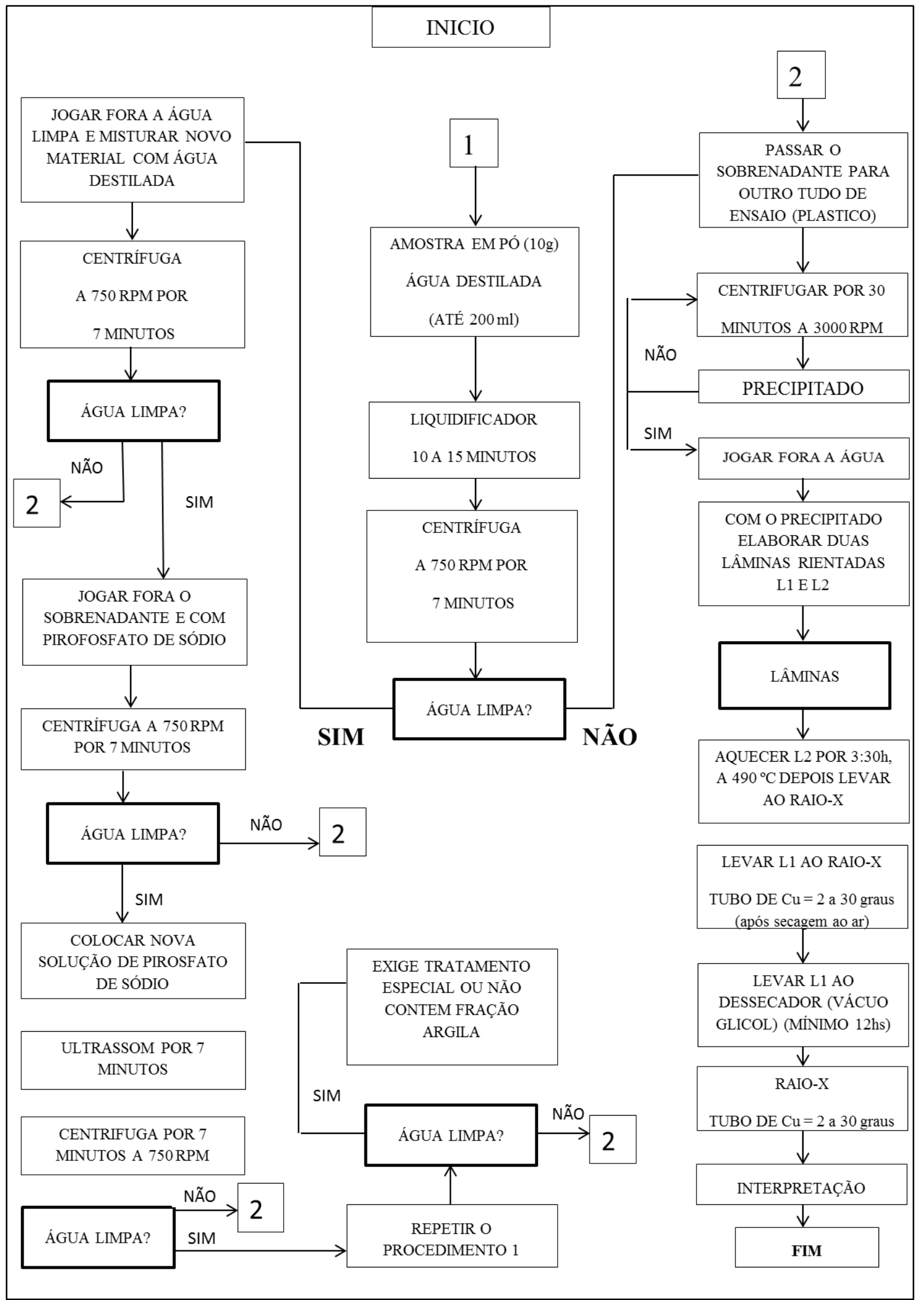

